\title{
Reactivity of homoleptic and heteroleptic core paddle wheel $\mathrm{Cu}$ (II) compounds
}

Francisco Sánchez-Férez ${ }^{a}$, Miguel Guerrero ${ }^{a}$, José A. Ayllón ${ }^{a}$, Teresa Calvet ${ }^{b}$, Mercè FontBardia ${ }^{c}$, José Giner Planas ${ }^{d}$, Josefina Pons ${ }^{a,{ }^{*}}$

aDepartament de Química, Universitat Autònoma de Barcelona, 08193-Bellaterra, Barcelona, Spain

${ }^{b}$ Mineralogia, Petrologia I Geologia Aplicada, Universitat de Barcelona, Martí I Franquès s/n, 08028-Barcelona, Spain

'Unitat de Difració de Raig-X, Centres Científics I Tecnològics de la Universitat de Barcelona (CCiTUB), Universitat de Barcelona, Solé i Sabarís, 1-3, 08028-Barcelona, Spain

${ }^{d}$ Instituto de Ciencia de los Materiales de Barcelona (CSIC), Campus UAB, 08193 Bellaterra, Spain 


\section{Abstract}

The compound $[\mathrm{Cu}(\mu-\mathrm{Pip})(\mu-\mathrm{OAc})(\mathrm{MeOH})]_{2}(1)(\mathrm{Pip}=$ Piperonylate, $\mathrm{OAc}=$ acetate, $\mathrm{MeOH}=$ methanol) has been obtained in a high percentage yields. Its reactivity with pyridine/pyrazole derivative ligands (pyridine (py), 3-phenylpyridine (3-Phpy) and 4-acetylpyridine (4-Acpy)) and 3,5-dimethylpyrazole (3,5-dmpz) leads to four monomeric compounds: $\left[\mathrm{Cu}(\mathrm{Pip})_{2}(\mathrm{dPy})_{2}\left(\mathrm{H}_{2} \mathrm{O}\right)\right]$ $\left(\mathrm{dPy}=\right.$ py (2), 3-Phpy (3) and 4-Acpy (4a)) and $\left[\mathrm{Cu}(\mathrm{Pip})_{2}(3,5-\mathrm{dmpz})_{2}\right](5)$. Furthermore, the reaction of 1 with HPip in MeOH:DMF solvent under reflux conditions yields the homoleptic core paddle-wheel compound $\left[\mathrm{Cu}(\mu-\mathrm{Pip})_{2}(\mathrm{DMF})\right]_{2} \cdot 2 \mathrm{DMF}(6)$. In the reaction between 6 and 2benzylpyridine (2-Bzpy) yields the paddle-wheel core compound $\left[\mathrm{Cu}(\mathrm{Pip})_{2}(2-\mathrm{Bzpy})\right]_{2}$ (7). All compounds have been fully characterized by analytical and spectroscopic techniques and their X-ray crystal structures have been determined. In this set of compounds, the carboxylate ligand (Pip) displays different coordination modes (monodentate (2-4), bidentate chelate (5) and bridged (1, 6 and 7)). Moreover, their supramolecular network is discussed: the crystal packing indicates hydrogen bond propagation defines 1D (2-5) or 2D (6 and 7) supramolecular networks. 


\section{Introduction}

The synthesis and characterization of crystalline materials build up by covalent bonds has gained an important interest, specially, the association of molecular compounds to form extended solids starting from secondary building units (SBUs) $[1,2]$. The assembly of metalcarboxylates for constructing new SBUs is an extensively exploited research field. These kind of compounds play an important role in synthetic chemistry, thanks to their labile coordination mode and even more important, in the design of porous frameworks [3].

Supramolecular chemistry is also an emergent research area, providing new complexes, which form chemical systems different from those linked with covalent bonds. These systems are composed of two or more assembled molecular subunits joined by relatively weak intermolecular forces (hydrogen bond, hydrophobic and $\pi$-interactions, van der Waals forces, and electrostatic effects) [1,4].

An important family of SBUs are $\mathrm{Cu}(\mathrm{II})$ and $\mathrm{Zn}$ (II) paddle-wheel complexes. There are more than 1,400 crystal structures containing $\mathrm{Cu}(\mathrm{II})$ with a $\left[\mathrm{Cu}_{2} \mathrm{~L}_{4}\right](\mathrm{L}=\mathrm{R}-\mathrm{COO})$ homoleptic core [5]. From those, only twelve present mixed bridged carboxylates $\left[\mathrm{Cu}(\mathrm{L})\left(\mathrm{L}^{\prime}\right)(\mathrm{X})\right]_{2}[6-16]$ in which six structures are accomplished via acetate bridging units [8-11, 13, 14]. There is not a rigorous explanation for its formation; steric hindrance could only play a significant role in three of them $[11,13]$. Recently, we have been studying the role of carboxylic acids in the structural arrangement. In this sense, reactions with 4-hydroxybenzoic acid (HpOHBz), (E)-3-(4hydroxyphenyl)-2-propenoic acid (para-hydroxycinnamic acid, HpOHcinn) and 1,3benzodioxole-5-carboxylic acid (Piperonylic acid, HPip) with Cu(II) [17-20], Zn(II) [21] and Cd(II) [21] have been already studied.

Herein, we focus on this novel compound with an heteroleptic paddle-wheel core $[\mathrm{Cu}(\mu-$ $\operatorname{Pip})(\mu-\mathrm{OAc})(\mathrm{MeOH})]_{2}$ (1) $(\mathrm{OAc}=$ acetate), recently obtained in our research group [18]. Homoleptic core paddle-wheel have been vastly used as starting building units for design of supramolecular [6] or polymeric [22] architectures while there is not any research with those 
containing a heteroleptic paddle-wheel core. Herewith, the reactivity of $\mathbf{1}$ with pyridine/pyrazole derivative ligands (pyridine (py, 2); 3-phenylpyridine (3-Phpy, 3); 4acetylpyridine (4-Acpy, 4) and 3,5-dimethylpyrazole (3,5-dmpz, 5)) have been studied, resulting in monomeric compounds $\left[\mathrm{Cu}(\mathrm{Pip})_{2}(\mathrm{dPy})_{2}\left(\mathrm{H}_{2} \mathrm{O}\right)\right](2-5)$. The displacement of the two remaining acetate units of 1 allow us to reach the homoleptic paddle-wheel $\left[\mathrm{Cu}(\mathrm{Pip})_{2}(\mathrm{DMF})\right]_{2} \cdot 2 \mathrm{DMF}(\mathbf{6})$ and gives us the possibility to perform further reactivity with 2-benzylpyridine ligand (2-Bzpy), which yields $\left[\mathrm{Cu}(\mathrm{Pip})_{2}(2-\mathrm{Bzpy})\right]_{2}$ (7) (Scheme 1).

\section{Experimental Section}

\subsection{Materials and methods}

$\mathrm{Cu}(\mathrm{II})$ acetate monohydrate $\left(\mathrm{Cu}(\mathrm{OAc})_{2} \cdot \mathrm{H}_{2} \mathrm{O}\right), 1$,3-benzodioxole-5-carboxylic acid (piperonylic acid, HPip), pyridine (py), 3-phenylpyridine (3-Phpy), 4-acetylpyridine (4-Acpy), 2benzylpyridine (2-Bzpy) and 3,5-dimethylpyrazole (3,5-dmpz) ligands; methanol (MeOH), N,Ndimethylformamide (DMF) and hexane were used as solvents. All of them were purchased from Sigma-Aldrich and used without further purification. Reactions and manipulation were carried out in air at room temperature (r.t.) for compounds 1-3 and under reflux conditions for 4-7. Elemental analysis (C, H, N) were carried out on a Thermo Scientific Flash 2000 CHNS Analyzer. The ATR-FTIR spectra were recorded on a Perkin Elmer spectrometer, equipped with a universal attenuated total reflectance (ATR) accessory with diamond window in the range 4000-550 $\mathrm{cm}^{-1}$. The electronic spectra in solution of $\mathrm{MeOH}\left(\approx 1 \cdot 10^{-3} \mathrm{M}\right)$ were run on a spectrophotometer Cary 500 Varian, equipped with a quartz cell having a path length of $1 \mathrm{~cm}$ in the range of 500-800 nm. Powder X-ray diffraction (PXRD) patterns were measured with a Siemens D5000 apparatus (with $40 \mathrm{~kW}$ and $45 \mathrm{~mA}$ using CuKa radiation with $\lambda=1.5406 \AA$ ). All of them were recorded from $2 \theta=5^{\circ}$ to $30^{\circ}$ with a step scan of $0.02^{\circ}$ counting $1 \mathrm{~s}$ at each step.

[Insert Scheme 1] 


\subsection{Synthetic procedures}

\subsection{1. $[\mathrm{Cu}(\mu-\mathrm{Pip})(\mu-\mathrm{OAC})(\mathrm{MeOH})]_{2}(1)$}

To a solution containing HPip (503 mg, $3.03 \mathrm{mmol}$ ) in $\mathrm{MeOH}(120 \mathrm{~mL})$, the green powder $\mathrm{Cu}(\mathrm{OAc})_{2} \cdot \mathrm{H}_{2} \mathrm{O}(550 \mathrm{mg}, 3.03 \mathrm{mmol})$ was added portion wise and stirred for $5 \mathrm{~h}$ at r.t, a green precipitate appeared immediately. The product was filtered off, washed with $10 \mathrm{~mL}$ of cold methanol and dried on air. Yield: $865 \mathrm{mg}$ (89\%). The same reaction was also performed in presence of $\mathrm{AcOH}$ acid $(3.0 \mathrm{~mL}$ ) with similar yield $(845 \mathrm{mg}, 87 \%)$ (S.I.: Fig. S1). Elem. Anal. Calc. for $\mathrm{C}_{22} \mathrm{H}_{24} \mathrm{O}_{14} \mathrm{Cu}_{2}(639.52 \mathrm{~g} / \mathrm{mol}): \mathrm{C} 41.32 ; \mathrm{H}$ 3.78. Found: C 41.05; H 3.54\%. ATR-FTIR (wavenumber, $\left.\mathrm{cm}^{-1}\right): 3301(\mathrm{~m})[\mathrm{v}(\mathrm{O}-\mathrm{H})]_{\mathrm{MeOH}}, 3060(\mathrm{w})\left[\mathrm{v}_{\mathrm{ar}}(\mathrm{C}-\right.$ $H)], 2955(w)\left[v_{a l}(C-H)\right], 1628(m), 1593(s) \quad\left[v_{a s}(C O O)\right], 1508(w) \quad\left[v_{a r}(C=C)\right], 1493(m)$, $1442(\mathrm{~s})\left[\mathrm{v}_{\mathrm{s}}(\mathrm{COO})\right], 1390(\mathrm{~s}), 1356(\mathrm{~m}), 1265(\mathrm{~s})[\delta(\mathrm{OH})], 1244(\mathrm{~m}), 1174(\mathrm{w}), 1117(\mathrm{~m})[\mathrm{v}(\mathrm{C}-$ O-C)], 1079(w), 1036(m), 1022(s) [ $\left.\delta_{\text {ip }}(C-H)\right], 935(w), 922(m), 884(w), 804(m), 775(s)$ $\left[\delta_{\text {oop }}(C-H)\right], 684(s)\left[\delta_{\text {oop }}(C-H)\right], 628(m)$. UV-Vis (Methanol, 1.1.10-3 M) $\lambda_{\max }(\varepsilon)=716(124)$ $\mathrm{nm}$.

\subsection{2. $\left[\mathrm{Cu}(\mathrm{Pip})_{2}(\mathrm{py})_{2}\left(\mathrm{H}_{2} \mathrm{O}\right)\right](2)$}

To a solution containing 1 (100 mg, $0.156 \mathrm{mmol})$ in $\mathrm{MeOH}(40 \mathrm{~mL})$, a solution of py $(0.25 \mathrm{~mL}, 3.13 \mathrm{mmol})$ in $\mathrm{MeOH}(10 \mathrm{~mL})$ was added dropwise and stirred for $1 \mathrm{~h}$. The solution turned dark blue and was subjected to several cooling-evaporation cycles. The resulting blue powder was filtered off, washed with $10 \mathrm{~mL}$ of cold methanol and dried on air. Suitable blue crystals were obtained after evaporation of mother liquors on air for 10 days. Yield: $55.2 \mathrm{mg}$ (62\%). Elem. Anal. Calc. for $\mathrm{C}_{26} \mathrm{H}_{22} \mathrm{~N}_{2} \mathrm{O}_{9} \mathrm{Cu}(569.99 \mathrm{~g} / \mathrm{mol})$ : $\mathrm{C}$ 54.78; H 3.89; N 4.91. Found: C 54.92; H 3.75; N 4.84\%. ATR-FTIR (wavenumber, $\mathrm{cm}^{-1}$ ): $3291(w)[v(O-H)]_{w a t e r}, 3071(w)\left[v_{a r}(C-H)\right], 2909(w)\left[v_{a l}(C-H)\right], 1607(m), 1579(s)\left[v_{a s}(C O O)\right]$, 1566(s), 1501(m), 1487(m), 1448(m), 1434(s) [v $(\mathrm{cOO})], 1379(\mathrm{~s}), 1346(\mathrm{~s}), 1255(\mathrm{~s})$, 1239(s), 1220(m) [ $\delta(\mathrm{OH}], 1166(\mathrm{~m}), 1109(\mathrm{~m})[\mathrm{v}(\mathrm{C}-\mathrm{O}-\mathrm{C})], 1073(\mathrm{~m}), 1035(\mathrm{~s})\left[\delta_{\mathrm{ip}}(\mathrm{C}-\mathrm{H})\right]$, 


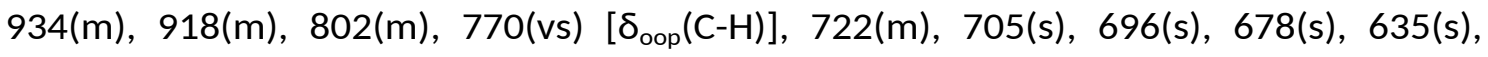
607(s), 583(s). UV-Vis (Methanol, 9.7·10-4 M) $\lambda_{\max }(\varepsilon)=710(33) \mathrm{nm}$.

\subsection{3. $\left[\mathrm{Cu}(\mathrm{Pip})_{2}(3-\mathrm{Phpy})_{2}\left(\mathrm{H}_{2} \mathrm{O}\right)\right](3)$}

To a solution containing 3-Phpy $(226 \mathrm{mg}, 0.313 \mathrm{mmol})$ in $\mathrm{MeOH}(10 \mathrm{~mL})$, a green solution of 1 (100 mg, $0.156 \mathrm{mmol})$ in $\mathrm{MeOH}(30 \mathrm{~mL})$ was added dropwise and stirred for $1 \mathrm{~h}$. The solution turned dark blue and was treated as 2 . Suitable blue crystals were obtained after evaporation of the mother liquors on air for 20 days. Yield: $63.3 \mathrm{mg}$ (56\%). Elem. Anal. Calc. for $\mathrm{C}_{38} \mathrm{H}_{30} \mathrm{~N}_{2} \mathrm{O}_{9} \mathrm{Cu}(722.18 \mathrm{~g} / \mathrm{mol}): \mathrm{C} 63.20 ; \mathrm{H} 3.19 ; \mathrm{N} 3.88$. Found: C 63.05; H 3.25; N 3.72\%. ATR-FTIR (wavenumber, $\left.\mathrm{cm}^{-1}\right): 3241(\mathrm{br})[\mathrm{v}(\mathrm{O}-\mathrm{H})]_{\text {water }}$, 3085(w) $\left[v_{\mathrm{ar}}(\mathrm{C}-\mathrm{H})\right], 2919(\mathrm{w})\left[\mathrm{v}_{\mathrm{al}}(\mathrm{C}-\mathrm{H})\right], 1569(\mathrm{~s})\left[\mathrm{v}_{\mathrm{as}}(\mathrm{COO})\right], 1500(\mathrm{w}), 1476(\mathrm{w}), 1439(\mathrm{~s})$, $1362(\mathrm{~s})\left[\mathrm{v}_{\mathrm{s}}(\mathrm{COO})\right], 1257(\mathrm{~m}), 1236(\mathrm{~s}), 1210(\mathrm{~m})\left[\delta(\mathrm{OH}], 1111(\mathrm{~m})[\mathrm{v}(\mathrm{C}-\mathrm{O}-\mathrm{C})], 1034(\mathrm{~s})\left[\delta_{\text {ip }}(\mathrm{C}-\right.\right.$

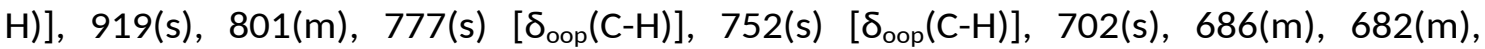
583(m). UV-Vis (Methanol, $\left.1.3 \cdot 10^{-3} \mathrm{M}\right) \lambda_{\max }(\varepsilon)=727(78) \mathrm{nm}$.

\subsection{4. $\left[\mathrm{Cu}(\mathrm{Pip})_{2}(4-\mathrm{Acpy})_{2}\left(\mathrm{H}_{2} \mathrm{O}\right)\right] \cdot 3 \mathrm{MeOH} \cdot \mathrm{H}_{2} \mathrm{O}(4 a)$}

To a solution containing 4-Acpy $(37.9 \mathrm{mg}, 0.313 \mathrm{mmol})$ in $\mathrm{MeOH}(10 \mathrm{~mL})$, a green solution of 1 (100 mg, $0.156 \mathrm{mmol})$ in $\mathrm{MeOH}(30 \mathrm{~mL})$ was added dropwise and stirred under reflux conditions for a day. The resulting dark green powder was filtered off, washed with $10 \mathrm{~mL}$ of cold methanol and dried under vacuum. Suitable blue crystals were obtained by slow evaporation of mother liquors on air for 14 days. The stoichiometry of this compound was definitely established after resolution of their Xray crystal structure. However, the occluded solvent molecules are withdrawn from the structure after manipulation required for preparing the sample for EA yielding $\left[\mathrm{Cu}(\mathrm{Pip})_{2}(4-\mathrm{Acpy})_{2}\left(\mathrm{H}_{2} \mathrm{O}\right)\right](4 \mathrm{~b})$. 
4a. Yield: $98.2 \mathrm{mg}(82 \%) . \mathrm{C}_{33} \mathrm{H}_{40} \mathrm{~N}_{2} \mathrm{O}_{15} \mathrm{Cu}\left(768.25 \mathrm{~g} / \mathrm{mol}\right.$ ). ATR-FTIR (wavenumber, $\mathrm{cm}^{-}$ $\left.{ }^{1}\right): 3350(\mathrm{~m})$ and $3265(\mathrm{~m})\left([\mathrm{v}(\mathrm{O}-\mathrm{H})]_{\mathrm{MeOH}}+[\mathrm{v}(\mathrm{O}-\mathrm{H})]_{\mathrm{water}}\right), 3055(\mathrm{w})\left[\mathrm{v}_{\mathrm{ar}}(\mathrm{C}-\mathrm{H})\right], 2917(\mathrm{~m})\left[\mathrm{v}_{\mathrm{al}}(\mathrm{C}-\right.$ $\mathrm{H})], 1696(\mathrm{~s})[\mathrm{v}(\mathrm{C}=\mathrm{O})]_{4-\mathrm{Acpy}}, 1660(\mathrm{w}), 1568(\mathrm{~s})\left[\mathrm{v}_{\mathrm{as}}(\mathrm{COO})\right], 1506(\mathrm{~m}), 1492(\mathrm{w}), 1440(\mathrm{~s})$, 1419(s) $\left[\mathrm{v}_{\mathrm{s}}(\mathrm{COO})\right], 1357(\mathrm{~s}), 1258(\mathrm{~s}), 1242(\mathrm{~s}), 1227(\mathrm{~s})[\delta(\mathrm{OH}], 1205(\mathrm{~m}), 1168(\mathrm{~m})$,

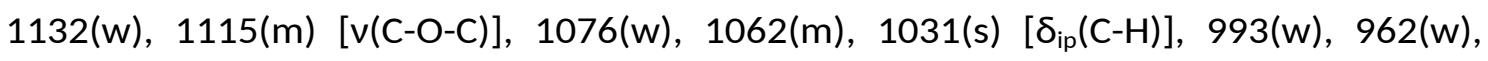

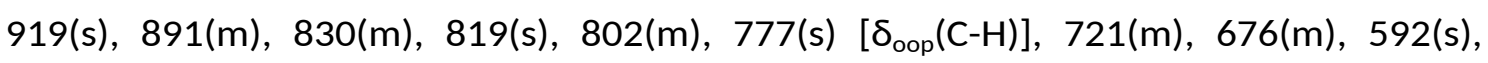
585(s). 4b. Yield: $83.1 \mathrm{mg}$ (82\%). Elem. Anal. Calc. for $\mathrm{C}_{30} \mathrm{H}_{26} \mathrm{~N}_{2} \mathrm{O}_{11} \mathrm{Cu}(636.09 \mathrm{~g} / \mathrm{mol}): \mathrm{C}$ 55.09; H 4.01; N 4.28. Found: C 55.23; H 4.30; N 4.40\%. ATR-FTIR (wavenumber, $\mathrm{cm}^{-1}$ ): 3049(m) $\left[v_{\mathrm{ar}}(\mathrm{C}-\mathrm{H})\right], 2919(\mathrm{w})\left[\mathrm{v}_{\mathrm{al}}(\mathrm{C}-\mathrm{H})\right], 1699(\mathrm{~s})[\mathrm{v}(\mathrm{C}=\mathrm{O})]_{4-\mathrm{Acpy}}, 1622(\mathrm{~s}), 1558(\mathrm{~s})\left[\mathrm{v}_{\mathrm{as}}(\mathrm{COO})\right]$, 1506(m), 1492(m), 1445(s), 1413(s), 1355(s), 1260(s), 1230(m), 1145(m), 1120(m) [v(CO-C)], 1082(w), 1062(w), 1029(m) [ $\left.\delta_{\text {ip }}(C-H)\right], 993(w), 961(w), 920(m), 870(m), 844(m)$,

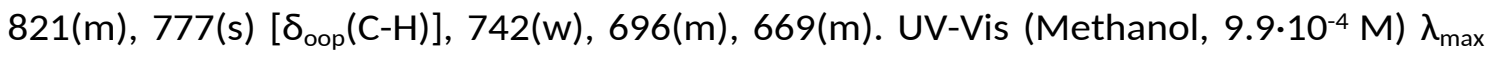
$(\varepsilon)=677(68) \mathrm{nm}$.

\subsection{5. $\left[\mathrm{Cu}(\mathrm{Pip})_{2}(3,5-d m p z)_{2}\right](5)$}

To a solution containing 3,5-dmpz (30.1 mg, $0.313 \mathrm{mmol})$ in $\mathrm{MeOH}(15 \mathrm{~mL})$, a green solution of 1 (100 mg, $0.156 \mathrm{mmol})$ in $\mathrm{MeOH}(25 \mathrm{~mL}$ ) was added dropwise and stirred under reflux conditions for $1 \mathrm{~h}$. The solution was evaporated almost half of the volume and a violet powder was formed. The powder was filtered and washed with $10 \mathrm{~mL}$ of cold $\mathrm{MeOH}$. Suitable violet crystals were obtained by slow evaporation of mother liquors on air for 5 days. Yield: $48.6 \mathrm{mg}$ (53\%). Elem. Anal. Calc. for $\mathrm{C}_{38} \mathrm{H}_{30} \mathrm{CuN}_{2} \mathrm{O}_{9}$ (586.05 g/mol): C 53.29; H 4.47; N 9.56. Found: C 53.17; H 4.35; N 9.45\%. ATR-FTIR (wavenumber, $\left.\mathrm{cm}^{-1}\right)$ : 3186-3105(m) $[\mathrm{v}(\mathrm{N}-\mathrm{H})], 3036(\mathrm{w})\left[\mathrm{v}_{\mathrm{ar}}(\mathrm{C}-\mathrm{H})\right], 2929(\mathrm{w})-2879\left[\mathrm{v}_{\mathrm{al}}(\mathrm{C}-\right.$ $H)], \quad 2783(w), \quad 1631(w), \quad 1604(w), \quad 1557(s) \quad\left[v_{\text {as }}(C O O)\right], 1501(s), \quad 1486(m), 1435(m)$ $\left[v_{s}(C O O)\right], 1381(s), 1341(s), 1300(m), 1257(m), 1240(s), 1189(m), 1166(w), 1143(w)$,

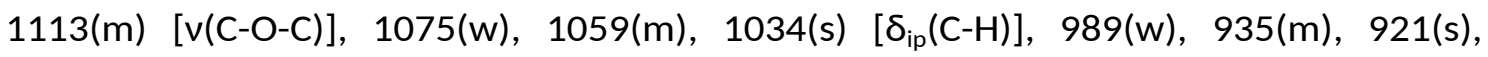




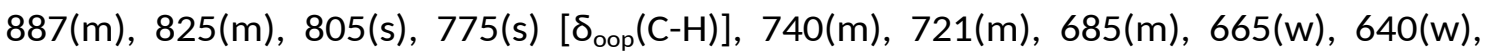
593(m/s), 560(m). UV-Vis: (Methanol, 9.5·10-4 M) $\lambda_{\max }(\varepsilon)=714(13) \mathrm{nm}$.

\subsection{6. $\left[\mathrm{Cu}(\mathrm{Pip})_{2}(\mathrm{DMF})\right]_{2} \cdot 2 \mathrm{DMF}(6)$}

Method A. To a colourless solution of HPip (51.9 mg, $0.313 \mathrm{mmol}$ ) in $\mathrm{MeOH}$ :DMF (2.5:1; $35 \mathrm{~mL})$, the green powder of $1(100 \mathrm{mg}, 0.157 \mathrm{mmol})$ was added and stirred under reflux conditions at $120{ }^{\circ} \mathrm{C}$ for $48 \mathrm{~h}$. The colour of the solution changed from green to dark blue. The resultant solution was treated with the sequential coolingevaporation process under vacuum. The resulting green powder was filtered off, washed with $10 \mathrm{~mL}$ of cold methanol and dried on air. Suitable green crystals were obtained in two days by slow diffusion of hexane in a DMF solution of 6. Yield: $112 \mathrm{mg}$ (65\%).

Method B. To a colourless solution of HPip (333 mg, $2.00 \mathrm{mmol}$ ) in MeOH:DMF (2.5:1, $50 \mathrm{~mL})$, the green powder $\mathrm{Cu}(\mathrm{OAc})_{2} \cdot \mathrm{H}_{2} \mathrm{O}(200 \mathrm{mg}, 1.00 \mathrm{mmol})$ was added portion wise and stirred under reflux conditions for $24 \mathrm{~h}$. Colour change from green to dark blue. The resultant solution was treated as mentioned before. Yield: $40.5 \mathrm{mg}$ (75\%). Elem. Anal. Calc. for $\mathrm{C}_{44} \mathrm{H}_{48} \mathrm{Cu}_{2} \mathrm{~N}_{4} \mathrm{O}_{20}$ (1079.94 g/mol): $\mathrm{C} 48.93 ; \mathrm{H} 4.48 ; \mathrm{N}$ 14.01. Found: $\mathrm{C} 48.72 ; \mathrm{H}$ 4.35; N 13.97\%. ATR-FTIR (wavenumber, $\left.\mathrm{cm}^{-1}\right): 2914(\mathrm{br})\left[\mathrm{v}_{\mathrm{al}}(\mathrm{C}-\mathrm{H})\right], 1678(\mathrm{~m})[\mathrm{v}(\mathrm{C}=\mathrm{O})]_{\mathrm{DMF}}$, $1661(\mathrm{~m}) \quad[\mathrm{v}(\mathrm{C}=\mathrm{O})]_{\mathrm{DMF}}, 1630(\mathrm{~m}), 1589(\mathrm{~m} / \mathrm{s}) \quad\left[\mathrm{v}_{\mathrm{as}}(\mathrm{COO})\right], 1497(\mathrm{~m}), 1487(\mathrm{~m}), 1437(\mathrm{~s})$ $\left[\mathrm{v}_{\mathrm{s}}(\mathrm{COO})\right], 1381(\mathrm{~s}), 1259(\mathrm{~s}), 1242(\mathrm{~s}), 1112(\mathrm{~m})[\mathrm{v}(\mathrm{C}-\mathrm{O}-\mathrm{C})], 1081(\mathrm{~m}), 1027(\mathrm{~s})\left[\delta_{\mathrm{ip}}(\mathrm{C}-\mathrm{H})\right]$,

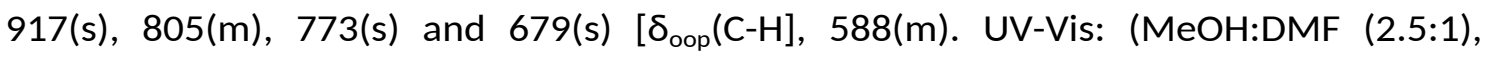
$\left.9.8 \cdot 10^{-4} \mathrm{M}\right) \lambda_{\max }(\varepsilon)=717(76) \mathrm{nm}$.

\subsection{7. $\left[\mathrm{Cu}(\mathrm{Pip})_{2}(2-\mathrm{Bzpy})\right]_{2}$ (7)}

Method A. To a green solution of 1 (100 mg, $0.156 \mathrm{mmol})$ and HPip $(51.9 \mathrm{mg}, 0.313$ $\mathrm{mmol})$ in $\mathrm{MeOH}(40 \mathrm{~mL})$, a yellowish solution of 2-Bzpy $(0.50 \mathrm{~mL}, 0.311 \mathrm{mmol})$ in $\mathrm{MeOH}$ 
(10 mL) was added dropwise and stirred under reflux conditions for $73 \mathrm{~h}$. The dark green solution was treated with sequential cooling-evaporating cycles and a green powder was formed. The powder was filtered. Suitable green crystals were obtained in five days by diffusion of the mother liquors in hexane. Yield: $50.5 \mathrm{mg}(48 \%)$.

Method B. To a green solution of $6(100 \mathrm{mg}, 0.093 \mathrm{mmol})$ in $\mathrm{MeOH}(40 \mathrm{~mL})$, a yellowish solution of 2-Bzpy $(0.30 \mathrm{~mL}, 0.186 \mathrm{mmol})$ in $\mathrm{MeOH}(10 \mathrm{~mL})$ was added dropwise and stirred under reflux conditions for $24 \mathrm{~h}$. The resulting solution was evaporated under vacuum until dryness and oil was formed. Crude oil was washed several times with hexane and remains vacuumed until a dark green powder was obtained. Yield: $52.3 \mathrm{mg}$ (50\%). Elem. Anal. Calc. for $\mathrm{C}_{56} \mathrm{H}_{40} \mathrm{Cu}_{2} \mathrm{~N}_{2} \mathrm{O}_{16}(1125.99 \mathrm{~g} / \mathrm{mol}): \mathrm{C}$ 58.53; H 4.44; N 4.40. Found: C 58.39; H 4.33; N 4.31\%. ATR-FTIR (wavenumber, $\mathrm{cm}^{-1}$ ): 3082(w) $\left[v_{a r}(C-H)\right], 2895(w)\left[v_{a l}(C-H)\right], 1634(m), 1594(s)\left[v_{a s}(C O O)\right], 1569(m), 1501(m)$, 1486(m), 1437(s) [v $(\mathrm{COO})], 1386(\mathrm{~s}), 1256(\mathrm{~s}), 1240(\mathrm{~m}), 1170(\mathrm{~m}), 1110(\mathrm{~m})[\mathrm{v}(\mathrm{C}-\mathrm{O}-\mathrm{C})]$, 1078(m), 1036(s) $\left[\delta_{\text {ip }}(C-H)\right], 924(m), 877(w), 804(m), 770(s)\left[\delta_{\text {oop }}(C-H)\right], 743(m), 721(m)$, 700(m), 683(s) $\left[\delta_{\text {oop }}(\mathrm{C}-\mathrm{H})\right], 613(\mathrm{~m}), 584(\mathrm{~m})$. UV-Vis: $\left(\mathrm{MeOH}, 1.1 \cdot 10^{-3} \mathrm{M}\right) \lambda_{\max }(\varepsilon)=689$ (86) $\mathrm{nm}$.

\subsection{X-ray single-crystal diffraction analysis}

The crystallographic data of complexes 2-4a and 5-7 are gathered in tables 1 and 2, respectively. Suitable crystals for X-ray diffraction were obtained by evaporation of mother liquors for 2-5, by DMF:hexane diffusion for 6 and by $\mathrm{MeOH}$ :hexane diffusion for 7. The X-ray intensity was measured on a D8 Venture system equipped with a multilayer mono-chromate and a Mo microfocus $(\lambda=0.71073 \AA$ ). A blue needle-like (24a), violet prism-like (5) and green prism-like $(6,7)$ were used for the X-ray crystallographic analysis. Frames were integrated with the Bruker SAINT Software package using a narrow-frame algorithm. The structures were solved using the Bruker 
SHELXTL Software, packaged and refined using SHELX (version-2018/3) [23]. Data were corrected for absorption effects using the multi-scan method (SADABS, version 2008/1). Crystal data and additional details of structure refinement for compounds 2-7 are included in the ESI (X-Ray crystal structures). Molecular graphics were generated using Mercury 3.9 software $[24,25]$. Colour codes for all molecular graphics are: orange $(\mathrm{Cu})$, blue $(\mathrm{N})$, red $(\mathrm{O})$, grey $(\mathrm{C})$ and white $(\mathrm{H})$. Crystal structure and molecular geometry is available in CIF format: CCDC 1851976-1851981 (2-7).

\section{[Insert Table 1]}

\section{[Insert Table 2]}

\section{Results and discussion}

\subsection{General}

The heteroleptic core compound $[\mathrm{Cu}(\mu-\mathrm{Pip})(\mu-\mathrm{OAc})(\mathrm{MeOH})]_{2}(1)$ was unexpectedly obtained in our group with $73 \%$ yield [18]. As a continuation of this study, in this paper the preparation and characterization of this compound with an $89 \%$ of yield is presented. The synthesis consists in the addition of solid $\mathrm{Cu}(\mathrm{OAc})_{2} \cdot \mathrm{H}_{2} \mathrm{O}$ over the HPip in $\mathrm{MeOH}$ as solvent. Addition of acetic acid to the reaction media did not affect the reaction product (see experimental). As mentioned in the introduction section, there are few reported examples of $\mathrm{Cu}(\mathrm{II})$-paddle-wheel complexes with heteroleptic core and their reactivity has not been described $[8-11,13,14]$. Herein, we present the reactivity study of a heteroleptic core compound with $\mathrm{N}$-donor ligands.

Once 1 has been synthesised and full characterized, its reactivity against pyridine (py, 2), 3phenylpyridine (3-Phpy, 3), 4-acetylpyridine (4-Acpy, 4a) and 3,5-dimethylpyrazole (3,5-dmpz, $5)$ in $\mathrm{MeOH}$ as solvent at r.t. $(2,3)$ or reflux $(4 a, 5)$ has been performed, resulting in four monomeric compounds: ([Cu((Pip) $\left.{ }_{2}(\mathrm{dPy})_{2}\left(\mathrm{H}_{2} \mathrm{O}\right)\right](\mathrm{dPy}=$ py (2), 3-Phpy (3) and 4-Acpy (4)) and $\left.\left[\mathrm{Cu}(\mathrm{Pip})_{2}(3,5-\mathrm{dmpz})_{2}\right]\right)(5)$ in moderate yields $(48-82 \%)$. Compound 3 has been previously 
reported by our research group [17] using a different synthetic approach and in a very low yield (12\%). In opposite, here we synthesise it as powder with a $56 \%$ of yield. The reactivity of 1, against $\mathrm{N}$-donor ligands, shows that $[\mathrm{Cu}(\mu-\mathrm{Pip})(\mu-\mathrm{OAc})]_{2}$ core is destroyed, resulting in monomeric compounds. The acetate ligands are displaced from 1, regardless of the pyridine/pyrazole ligands used, and Pip ligands remain coordinated to the metal centre. In complexes 2-4a the five-membered $\mathrm{Cu}(\mathrm{II})$ coordination sphere is completed by a water molecule and two pyridine derived ligands. In complex 5, the six-membered coordination sphere is fulfilled by the pyrazole ligand and the bidentate chelate coordination mode of the two Pip ligands on its own (Scheme 1).

The reaction of 1 with HPip in MeOH:DMF (2.5:1) as solvent under reflux conditions yields $\left[\mathrm{Cu}(\mathrm{Pip})_{2}(\mathrm{DMF})\right]_{2} \cdot 2 \mathrm{DMF}(6)$. This compound displays a homoleptic core paddle-wheel structure with DMF molecules in the apical positions. Most interestingly, the reaction between 6 and 2benzylpyridine (2-Bzpy) in $\mathrm{MeOH}$ as solvent under reflux conditions results in $\left[\mathrm{Cu}(\mathrm{Pip})_{2}(2-\right.$ Bzpy) $]_{2}(7)$, which maintain its paddle-wheel structure (Scheme 1). Compound 7 is also obtained from 1 by its reaction with HPip in presence of 2-Bzpy.

All compounds were characterized by PXRD and analytical and spectroscopic techniques. Spectroscopic characterization details of all compounds are in the experimental section and in the S.I. For complexes 1-3, 5-7, phase purity of the bulk samples was confirmed by X-ray powder diffraction (S.I.: Fig. S1-S7). Elemental analyses for these compounds agree with the proposed formula. For compound 4, X-ray powder diffraction and elemental analyses are in accordance with the formula $\left[\mathrm{Cu}(\mathrm{Pip})_{2}(4-\right.$ Acpy) $\left.)_{2}\left(\mathrm{H}_{2} \mathrm{O}\right)\right]$ (4b) due to the loss of solvent molecules ( $3 \mathrm{MeOH}$ and $\mathrm{H}_{2} \mathrm{O}$ ).

The IR spectra of compounds 1-7 display the characteristic carboxylate bands in the range $1593-1550 \mathrm{~cm}^{-1}$ for $v_{\text {as }}(\mathrm{COO})$ and $1442-1356 \mathrm{~cm}^{-1}$ for $\mathrm{v}_{\mathrm{s}}(\mathrm{COO})$. The difference between these bands $\left(\Delta=v_{\text {as }}(\mathrm{COO})-\mathrm{v}_{\mathrm{s}}(\mathrm{COO})\right)[26,27]$ for dimeric compounds 1,6 and 7 is 151,154 and $157 \mathrm{~cm}^{-1}$, respectively, indicating a bridging coordination mode (S.I.: Fig. 
S8, S13 and S14, respectively). For compounds 2-4 the values of $\Delta$ are 200, 207 and 212 $\mathrm{cm}^{-1}$, respectively, corresponding to a monodentate coordination mode (S.I.: Fig. S9 S11, respectively). Finally, for compound 5 this value is $122 \mathrm{~cm}^{-1}$, which indicates a bidentate chelate coordination mode of the carboxylate moieties (S.I.: Fig. S12). The bands attributable to the aromatic groups, $\mathrm{v}_{\mathrm{as}}(\mathrm{C}=\mathrm{C})_{\mathrm{ar}}, \mathrm{v}_{\mathrm{as}}(\mathrm{C}=\mathrm{N})_{\mathrm{ar}}, \delta(\mathrm{C}-\mathrm{H})_{\mathrm{ip}}$ and $\delta(\mathrm{C}-\mathrm{H})_{\mathrm{oop}}$, are also present [28]. The presence of solvent molecules allows further identification of some specific bands. Compound 1 shows the $\mathrm{v}(\mathrm{O}-\mathrm{H})_{\mathrm{MeOH}}$ at $3301 \mathrm{~cm}^{-1}$ and $2-4$ the $\mathrm{v}(\mathrm{O}-$ $\mathrm{H})_{\text {water }}$ bands appears in the range $3312-3241 \mathrm{~cm}^{-1}$. Also the $\delta(\mathrm{O}-\mathrm{H})$ can be assigned in these four compounds. Moreover, for compounds 4 and $\mathbf{6}$, bands attributable to $v(C=O)$ from 4-Acpy (4a, 4b) or DMF (6) units appear in the range $1696-1661 \mathrm{~cm}^{-1}$. The IR spectral data, therefore, agree with the structures determined by the X-ray singlecrystal diffraction method.

\subsection{Structural studies}

\subsubsection{Crystal and extended structure of compounds $2-4 a$}

Compounds 2-4a crystallize in the monoclinic C2/c space group. They have a monomeric structure with a $\left[\mathrm{CuO}_{3} \mathrm{~N}_{2}\right]$ core comprising a pair of each monodentate ligands, Pip and dpy (py (2) (Fig. 1a), 3-Phpy (3) (Fig. 1b) or 4-Acpy (4a) (Fig. 1c)) and a water molecule. There are more than 1,500 structures [29] with this core and only sixteen of these contain two oxygen atoms from a pair of carboxylates and one from a water molecule [5]. Five-coordinate compounds can adopt trigonal bipyramidal $\left(D_{3 h}\right)$, square-pyramidal $\left(\mathrm{C}_{4 \mathrm{v}}\right)$ or intermediate $\left(\mathrm{C}_{2 \mathrm{v}}\right)$ geometries. Several parameters are stablished to distinguish between them: the $\tau$ value which range from $1\left(D_{3 h}\right)$ to $0\left(C_{4 v}\right)$ [30], the $L_{\text {apical }}-M-L_{\text {basal }}$ angle $\left(102^{\circ}\right.$ for $\left.C_{4 v}\right)$ or the dihedral angles between the apical faces $\left(53.1^{\circ}\right.$ for $D_{3 h}, 75.7^{\circ}$ for $\left.C_{4 v}\right)$ and the apical-basal faces $\left(101.5^{\circ}\right.$ for $D_{3 h}, 119.8^{\circ}$ for $\mathrm{C}_{4 \mathrm{v}}$ ) [31]. All these compounds clearly exhibit a $\mathrm{C}_{4 \mathrm{v}}$ geometry, taking into account these 
three factors: $\tau$ (0.205 (2), 0.053 (3), 0.282 (4a)), L-M-L angle (Cu-N1, 97.32 (2), Cu-N1, 93.58 ${ }^{\circ}(3), \mathrm{Cu}-\mathrm{N} 1,95.92^{\circ}$ ) and dihedral angles (apical faces: $60.22^{\circ}-79.35^{\circ}(2), 62.29^{\circ}-$ $76.24^{\circ}$ (3), $61.16^{\circ}-78.29^{\circ}$ (4a); apical-basal: $120.11^{\circ}-120.27^{\circ}$ (2), $121.14^{\circ}-121.02^{\circ}$ (3), $\left.120.58^{\circ}-121.19^{\circ}(4 a)\right)$. The apical sites of the square-pyramidal geometries are occupied

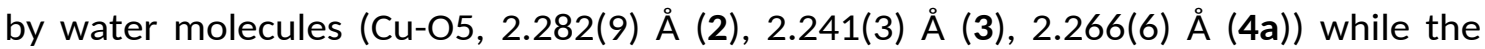
basal plane contains the supplementary ligands in trans disposition.

\section{[Insert Figure 1]}

\section{[Insert Table 3]}

All the $\mathrm{Cu}-\mathrm{O}$ and $\mathrm{Cu}-\mathrm{N}$ distances for the three compounds are in the same order as described in the literature [17, 32-36] (Table 3). For 2, Cu(II) ion is $0.109 \AA$ displaced out of the basal plane towards the axial site while in $\mathbf{3}$ and $4 \mathrm{a}, \mathrm{Cu}(\mathrm{II})$ ion is displaced $0.029 \AA$ and $0.062 \AA$, respectively. The twisting of the $N$-donor ligands produces these displacements and deviation increases $2>4 a>3$.

Compounds 2-4a, present supramolecular 1D-chains $(2,3)$ along the $b$ axis (Fig. 2a and 3a, respectively) or 2D-layers (4a) along the bc plane (Fig. 4a).

\section{[Insert Figure 2]}

\section{[Insert Figure 3]}

\section{[Insert Figure 4]}

The 1D linear chain formation is supported by two bridging symmetrically interactions in which apical water molecule acts as a heteromeric intermolecular synthon through hydrogen bond interaction with the non-coordinated carboxylate oxygen atoms. These hydrogen bond interactions are moderately strong with $\mathrm{D}-\mathrm{H} \cdots \mathrm{A}$ distances $(\mathrm{O} 5-\mathrm{H} 5 \cdots \mathrm{O} 2,1.90(15) \AA(2) ; 1.87(2) \AA(3) ; 1.97(8) \AA(4 a))$ and bond angles $\left(167(18)^{\circ}(2), 170(3)(3), 172(14)^{\circ}(4 a)\right)$, which are characteristic of strong interactions [37]. Moreover, compound 2 presents a hydrogen bond interaction between one dioxole oxygen atom of a piperonylate moiety and the hydrogen of a neighboring 
stacked in a row piperonylate aromatic ring (C9-H9...04, 2.325(8) $\left.\AA, 166(18)^{\circ}\right)$. This interaction is driven by the carboxylates spatial disposition that supports the supramolecular expansion (Fig. 2b). In contrast, the twisting of the Pip units in 3 and $4 a$

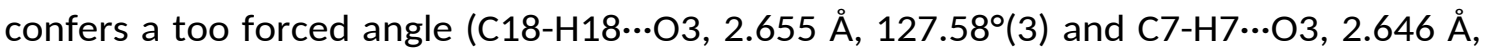
$\left.133.95^{\circ}(4 a)\right)$ and avoids the H-bond interaction formation (Fig. 3b). Furthermore, the addition of the acetyl group in 4a allows the formation of supplementary interactions: one aliphatic hydrogen of the acetyl group interacts with the oxygen atom of the dioxole ring propagating the $1 \mathrm{D}$ chain along the $\mathrm{c}$ axis and forming $2 \mathrm{D}$ layers along the bc plane. Interestingly, there are few structures with similar 1D chain with a double Hbond interaction belonging from water - carboxylate [17, 32-36], which distinguishes compound $4 \mathrm{a}$ from the rest is the presence of three methanol and one occluded water molecules. Its supramolecular 2D square-grid extended structure (Fig. 4b) generates channels that are filled by guest methanol and water solvent molecules. The solvent accessible volume of these channels is a $6.2 \%$ of the cell volume. On standing in air, the guest solvent is lost, as indicated by elemental analysis results, although aqua ligand is not. PXRD of the aerated sample denotes that the initial crystal structure has been modified (S.I.: Fig. S4). Unfortunately, these changes seem to provoke the collapse of the pores, and the materials does not adsorb any significant amount of nitrogen.

\subsubsection{Crystal and extended structure of compound 5}

Compound 5 crystallizes in the triclinic $P$-1 space group with two crystallographically independent units enclosed in the unit cell (molecules $\mathbf{A}$ and $\mathbf{B}$ ). Each unit has a monomeric structure with a $\left[\mathrm{CuO}_{4} \mathrm{~N}_{2}\right]$ core (Figure 5a) comprising a pair of carboxylate units with a syn-syn chelate array (Cu-O $1.965 \AA$ - $2.653 \AA$ ) and a pair of monodentate 3,5-dmpz moieties (Cu-N $1.975 \AA-1.977 \AA$ ). It has an inversion center at the metal node, which relates the two carboxylates and the two 3,5-dmpz ligands. This compound 
presents a distorted octahedral molecular geometry with a significant $\mathrm{O}_{\mathrm{ax}}-\mathrm{Cu}-\mathrm{O}_{\mathrm{eq}}$ angle deviation (A, $55.02^{\circ}$ and $124.98^{\circ} ; \mathbf{B}, 55.90^{\circ}$ and $124.10^{\circ}$ ). The equatorial plane is comprised by two shorter distance carboxylate oxygen atoms ( $\mathrm{O} 1 \mathrm{~A}$ and $\mathrm{O} 1 \mathrm{~B})$ and two pyrazolic nitrogen atoms (N1A and N1B), which are in range of other reported compounds described in the literature $\left[\mathrm{Cu}(\mathrm{Hdmpz})_{2}(\mathrm{~L})_{2}\right](\mathrm{L}=$ 4-methylbenzoate, 3-

methylbenzoate, 2-chlorobenzoate, 4-methoxybenzoate [3]; $\left[\mathrm{Cu}\left(\mathrm{C}_{4} \mathrm{H}_{4} \mathrm{O}_{5}\right)\left(\mathrm{C}_{5} \mathrm{H}_{8} \mathrm{~N}_{2}\right)_{2}\left(\mathrm{H}_{2} \mathrm{O}\right)\right] \cdot 2 \mathrm{H}_{2} \mathrm{O} \quad[38], \quad\left[\mathrm{Cu}_{4} \mathrm{Cl}_{2}\right.$ (oxalate) $(\mathrm{pz})_{2}((1-$ hydroxymethyl)pyrazole) $\left.{ }_{2}\right]_{\mathrm{n}}$ [39] (Table 4). The asymmetric furthest oxygen atoms [4044], which are typically generated in chelate carboxylates due to the Jahn-Teller effect [45] occupy the axial sites. In addition, this six coordinate array is underpinned by the elongation of the C-O carboxylic bond length (C1A-O2A $1.247 \AA$, C1B-O2B $1.248 \AA$ ) respect to the C-O bond of the uncoordinated piperonylic acid (1.214 - 1.223 $\AA$ ), clearly suggesting that this oxygen is coordinated [44].

The propagation of intermolecular interactions defines 1D chains along the $a$ axis with all the ligands stacked in a row (Figure 5b). The main association in this system is the $\mathrm{N}$-pyrazolic donor-carboxylate, which generates a double $\mathrm{H}$-bond interaction. The protonated nitrogen of the pyrazole ring interacts with the coordinated carboxylic oxygen of the asymmetric chelate with the largest $\mathrm{Cu}-\mathrm{O}$ distance (N2A-H2A $\cdots \mathrm{O} 2 \mathrm{~A}$, $1.940(14) \AA, 154.10^{\circ}$ (15)) forming this kind of supramolecular chains (Table 5).

[Insert Figure 5]

[Insert Table 4]

[Insert Table 5]

\subsubsection{Crystal structures of compounds 6 and 7}

Compounds 6 (Fig. 6a) and 7 (Fig. 6b) crystallize in the triclinic P-1 space group. These compounds are dimers with four symmetrically located ligand moieties orientated in a syn-syn bidentate bridging mode with the carboxylic oxygen atoms coordinating two $\mathrm{Cu}(\mathrm{II})$ nodes and 
anchoring the paddle-wheel-like structure. In both compounds, each $\mathrm{Cu}(\mathrm{II})$ node has a squarepyramidal geometry consisting an one apical DMF (6) or 2-Bzpy (7) moiety and four oxygen atoms from the bridging carboxylate groups at the basal plane.

\section{[Insert Figure 6]}

Selected distances and angles are provided in Table 6. Compound 6 has the apical units (Cu1-O9) at 2.1540(15) $\AA$ while compound 7 (Cu1B-N1B) at 2.243(8) $\AA$. The remaining Cu-O distances of the basal plane are in the range 1.959(6) $\AA$ and 1.982(7) $\AA$, which are shorter than apical $\mathrm{N}$ atoms due to the Jahn-Teller effect [45] but comparable to similar paddle-wheel structures described in the literature (1.945 $\AA$ to $2.008 \AA$ ) [17, $22,46-51]$.

\section{[Insert Table 6]}

For compound 7, two crystallographically independent dimeric molecules (A and B) are present in the unit cell.

In both structures, $\mathrm{Cu}(\mathrm{II})$ ions are displaced from the oxygen atoms plane $(0.182 \AA$ (6); $0.212 \AA(7))$ towards the apical position. In addition, the square base angles range from $87.45^{\circ}$ to $169.37^{\circ}$ with a slight deviation of the square-planar geometry $(\tau=0.0035$ (6) and $\tau=0.0072(7))$ [33]. The $\mathrm{Cu} \cdots \mathrm{Cu}$ intermolecular distances are 2.6057(5) $\AA$ and 2.656(1) $\AA$, (6 and 7, respectively). In 6, this $\mathrm{Cu} \cdots \mathrm{Cu}$ distance is a little bit shorter than other similar structures $(2.610 \AA-2.713 \AA)$ [17, 22, 45-50]. It is worthwhile to mention that compound 7 presents the largest angle (O2A-Cu1A-N1A, 99.40 $)$ which corresponds to the carboxylate oxygen closest to the 2-Bzpy ligand. The steric hindrance of the benzyl rings could promote its orientation and the angle opening of the nearest carboxylate ligand (Fig. 6b). 


\subsubsection{Extended structures of compounds 6 and 7}

For compound 6, all the intermolecular interactions are based on coordinated and the uncoordinated DMF molecules. The first intermolecular interaction is the homomeric asymmetric amide-amide interaction between them (C5-H5B …09, 2.407(3)

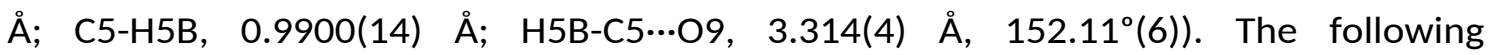
interactions are between aliphatic proton from each of two Pip units and an uncoordinated DMF molecule through its carboxylic oxygen atom, which also interacts with a coordinated DMF of a neighbouring paddle-wheel forming 1D chains along the $a$

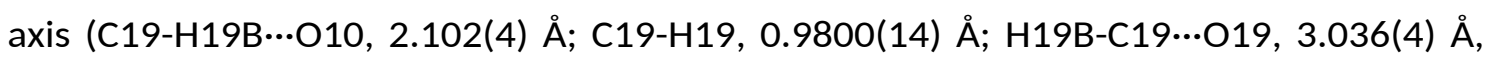
$\left.158.54^{\circ}(6)\right)$ (Fig. 7a). The remaining pair of Pip units interacts directly with a coordinated DMF molecule of other neighbouring paddle-wheel (Fig. 7b) generating 2D layers along the $\left(00^{1 / 2}\right)$ plane $(\mathrm{C} 13-\mathrm{H} 13 \mathrm{~A} \cdots \mathrm{O} 10,2.163(4) \AA$; $\mathrm{C} 13-\mathrm{H} 13 \mathrm{~A}, 0.9900(16) \AA$

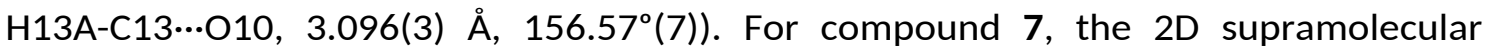
structure is generated by the propagation in the $b c$ plane through two alternated simultaneous hydrogen bond interactions. Each dimeric unit possesses four propagation centres, two from the 2-Bzpy units (Fig. 8a) and two from the piperonylate units (Fig. 8b). These two crystallographically different 2-Bzpy rings interacts with the

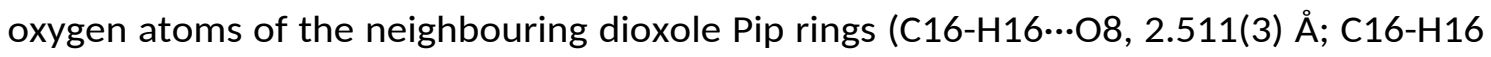

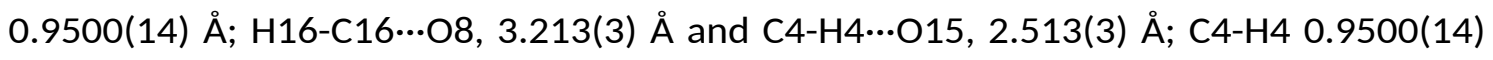
$\AA$ A $\mathrm{H} 4-\mathrm{C} 4 \cdots \mathrm{O} 15,3.165(3) \AA ̊$ ) and constructing 2D layer.

\section{[Insert Figure 7]}

\section{[Insert Figure 8]}

\subsection{UV-Vis spectroscopy}

UV-Vis electronic spectra for all the compounds have been recorded in methanol (15, 7) or $\mathrm{MeOH}: \mathrm{DMF}(2.5: 1)(6)$ as solvent. All spectra show one band in the visible region, between 727 and $677 \mathrm{~nm}$ with $\varepsilon=13-124 \mathrm{M}^{-1} \mathrm{~cm}^{-1}$ (S.I.: Fig. S15). For a $\mathrm{d}^{9}$ ion, 
with a ${ }^{2} \mathrm{D}$ term, there is only one transition between the two levels ${ }^{2} \mathrm{E}_{\mathrm{g}}$ and ${ }^{2} \mathrm{~T}_{2 \mathrm{~g}}$. In the octahedral crystalline field, the spin-orbital coupling unfolds the ${ }^{2} T_{2 g}$ level in two sublevels due to its tetragonal distortion (Jahn-Teller effect). For these reason, an octahedral $d^{9}$ ion has two possible transitions, both from the ${ }^{2} E_{g}$ level to each of the unfolded ${ }^{2} \mathrm{~T}_{2 \mathrm{~g}}$ sublevels giving two absorption bands. However, in the case of $\mathrm{Cu}$ (II) these sublevels are energetically close and the difference in energy is too small to discriminate between them resulting in a broad band $[52,53]$. The energy of these electronic transitions depends on the fulfilment of the two selection rules (Laporte and spin). Electronic transitions in $\mathrm{d}^{9} \mathrm{Cu}(\mathrm{II})$ complexes only accomplish the spin rule, for this reason the energy of this transitions is lower than other transition metal complexes and its $\varepsilon$ values range from 10 to $200 \mathrm{~mol}^{-1} \mathrm{~cm}^{-1}$. The obtained values for compound $1-7$ are in accordance with the values reported in the literature for similar $\mathrm{Cu}(\mathrm{II})$ complexes (Table 7) [18, 54-57].

\section{[Insert Table 7]}

\section{Conclusions}

The reactivity of the heteroleptic core compound 1 with selected supplementary ligands (py, 3-Phpy, 4-Acpy and 3,5-dmpz) results in the rupture of the dimeric array and yields four monomeric species (2-5). In opposite, the reaction between the homoleptic core compound 6 with the 2-Bzpy ligand yield the dimeric compound 7 , keeping the paddle-wheel building unit. It is worthwhile to mention that even there are similar heteroleptic core previously described in the literature [6-16]; there are few studies about their reactivity. In this juncture, besides presenting the first trial in this sense, it is also remarkable the different behaviour exhibited by the two paddle-wheel compounds $(1,6)$. This difference can only be promoted by the fact of having mixed bridges. 


\section{Conflicts of interest}

There are no conflicts to declare.

\section{Acknowledgements}

This work was financed by the Spanish National Plan of Research MAT2015-65756-R, CTQ2016-75150-R and 2017SGR1687, 2014SGR149 projects from the Generalitat de Catalunya for financial support.

\section{Appendix A. Supplementary material}

CCDC: 1851976-1851981 contain the supplementary crystallographic data for

compounds 2-7. The data can be obtained free of charge via http://www.ccdc.cam.ac.uk/conts/retrieving.html, or from the Cambridge Crystallographic Data Centre, 12 Union Road, Cambridge CB2 1EZ, UK; fax:(+44)1223-336033; or e-mail: deposit@ccdc.cam.ac.uk.

PXRD patterns and additional ATR-FTIR spectra figures are available as electronic supplementary information in the online version. 


\section{References}

[1] J. M. Lehn, Chem. Soc. Rev., 36 (2007) 151-160.

[2] L. Zhao and F. Guo, J. Coord. Chem., 66 (2013) 2940-2947.

[3] S. W. Jin, X. H. Ye, L. Jin, L. Zheng, J. W. Li, B. P. Jin and D. Q. Wang, Polyhedron, 81 (2014) 382-395.

[4] B. Olenyuk, M. D. Levin, J. A. Whiteford, J. E. Shield and P. J. Stang, J. Am. Chem. Soc., 121 (1999) 10434-10435.

[5] C. R. Groom, I. J. Bruno, M. P. Lightfoot and S. C. Ward, Acta Crystallogr. Sect. B Struct. Sci. Cryst. Eng. Mater., 72 (2016) 171-179.

[6] K. Hassanein, O. Castillo, C. J. Gómez-García, F. Zamora and P. Amo-Ochoa, Cryst. Growth Des., 15 (2015) 5485-5494.

[7] I. Galkina, A. Tufatullin, D. Krivolapov, Y. Bakhtiyarova, D. Chubukaeva, V. Stakheev, V. Galkin, R. Cherkasov, B. Büchner and O. Kataeva, CrystEngComm, 16 (2014) 9010-9024.

[8] B. Kozlevčar, D. Odlazek, A. Golobič, A. Pevec, P. Strauch and P. Šegedin, Polyhedron, 25 (2006) 1161-1166.

[9] W. Ying, L. Xiao-Meng, B. Feng-Ying, Z. Rui, Chinese J. Inorg. Chem., 33 (2017) 16671677.

[10] G. Vives, S. A. Mason, P. D. Prince, P. C. Junk and J. W. Steed, Cryst. Growth Des., 3 (2003) 699-704.

[11] D. Maspoch, D. Ruiz-Molina, K. Wurst, C. Rovira and J. Veciana, Chem. Commun., (2002) 2958-2959.

[12] D. Maspoch, D. Ruiz-Molina, K. Wurst, J. Vidal-Gancedo, C. Rovira and J. Veciana, Dalton Trans., 7 (2004) 1073-1082.

[13] L. S. Erre, G. Micera, P. Piu, F. Cariati and G. Ciani, Inorg. Chem., 24 (1985) 2297-2300.

[14] A. A. Ageshina, M. A. Uvarova and S. E. Nefedov, Russ. J. Inorg. Chem., 60 (2015) 10851092.

[15] M. A. Bañares, L. Dauphin, X. Lei, W. Cen, M. Shang, E. E. Wolf and T. P. Fehlner, Chem. Mater., 7 (1995) 553-561.

[16] J.-H. Luo, C.-C. Huang, X.-H. Huang and J.-G. Wang, Acta Crystallogr. Sect. C Cryst. Struct. Commun., 64 (2008) m121-m122.

[17] J. Soldevila-Sanmartín, J. A. Ayllón, T. Calvet, M. Font-Bardia and J. Pons, Polyhedron, 126 (2017) 184-194.

[18] J. Soldevila-Sanmartín, J. A. Ayllón, T. Calvet, M. Font-Bardia, C. Domingo and J. Pons, Inorg. Chem. Commun., 71 (2016) 90-93.

[19] J. Soldevila-Sanmartín, T. Calvet, M. Font-Bardia, C. Domingo, J.A. Ayllón, J. Pons, Dalt. Trans., 47 (2018) 6479-6493.

[20] M. Sanchez-Sala, J. Pons, Á. Álvarez-Larena, C. Domingo and J. A. Ayllón, 
ChemistrySelect, 2 (2017) 11574-11580.

[21] M. Guerrero, S. Vázquez, J. A. Ayllón, T. Calvet, M. Font-Bardia and J. Pons, ChemistrySelect, 2 (2017) 632-639.

[22] M. Barquín, N. Cocera, M. J. González Garmendia, L. Larrínaga, E. Pinilla and M. R. Torres, J. Coord. Chem., 63 (2010) 2247-2260.

[23] G. M. Sheldrick, Acta Crystallogr. Sect. A Found. Crystallogr., 64 (2007) 112-122.

[24] C. F. Macrae, P. R. Edgington, P. McCabe, E. Pidcock, G. P. Shields, R. Taylor, M. Towler and J. Van De Streek, J. Appl. Crystallogr., 39 (2006) 453-457.

[25] C. F. Macrae, I. J. Bruno, J. A. Chisholm, P. R. Edgington, P. McCabe, E. Pidcock, L. Rodriguez-Monge, R. Taylor, J. Van De Streek and P. A. Wood, J. Appl. Crystallogr., 41 ( 2008) 466-470.

[26] K. Nakamoto, Infrared and Raman Spectra of Inorganic and Coordination Compounds Part A : Theory and Applications, 6th ed. New York, USA. (2009).

[27] R. J. Deacon and G.B. Phillips, Coord. Chem. Rev., 33 (1980) 227-250.

[28] D. H. Williams, Spectroscopic methods in organic chemistry, McGraw-Hill, London, UK, (2008).

[29] Cambridge Structural Database (CSD) (Version 5.37) 2016.

[30] A. W. Addison and T. N. Rao, J. Chem. Soc., Dalton. Trans., 1 (1984) 1349-1356.

[31] E. L. Muetterties, Tetrahedron, 30 (1973) 1595-1604.

[32] Y. Li, X. Meng, L. Cao, Y. Wang, G. Yin, M. Gao, L. Wen and A. Wu, Cryst. Growth Des., 8 (2008) 1645-1653.

[33] F. Valach, R. Grobelny, T. Glowiak, J. Mrozinski, V. LUKEŠ and Z. Blahova, J. Coord. Chem., 63 (2010) 1645-1651.

[34] S. Jin, H. Liu, G. Chen, Z. An, Y. Lou, K. Huang and D. Wang, Polyhedron, 95 (2015) 91107.

[35] J. Moncol', M. Palicová, P. Segl'a, M. Koman, M. Melnı 'k, M. Valko and T. Glowiak, Polyhedron, 21 (2002) 365-370.

[36] F. Hamza and G. Kickelbick, Macromolecules, 42 (2009) 7762-7771.

[37] T. Steiner, Angew. Chem. Int. Ed., 41 (2002) 49-76.

[38] Y.-L. Wang, G.-J. Chang and B.-X. Liu, Acta Crys., E67 (2011) m682-m682.

[39] A. M. López Marzo, M. Guerrero, T. Calvet, M. Font-Bardia, E. Pellicer, M. D. Baró, J. Pons and J. Sort, RSC Adv., 5 (2015) 32369-32375.

[40] J. Moncol, K. Jomova, L. Zelenicky, T. Lis and M. Valko, Acta Cryst., C67 (2011) 318-320.

[41] U. Turpeinen, R. Hämäläinen and J. Reedijk, Inorg. Chim. Acta, 154 (1988) 201-207.

[42] J. Valdés-Martínez, R. A. Toscano and J. Ramirez-Ortíz, Polyhedron, 14 (1995) 579-583. 
[43] A. F. Cameron, K. P. Forrest, D. W. Taylor and R. H. Nuttall, J. Chem. Soc. (A), (1971), 2492-2496.

[44] S. Šćavničar and B. Matković, Acta Crystallogr. Sect. B Struct. Crystallogr. Cryst. Chem., 25 (1969) 2046-2055.

[45] L. R. Falvello, J. Chem. Soc., Dalt. Trans., (1997) 4463-4475.

[46] M. Guerrero, J. A. Ayllón, T. Calvet, M. Font-Bardia and J. Pons, Polyhedron, 134 (2017) 107-113.

[47] P. M. Selvakumar, S. Nadella, J. Sahoo, E. Suresh and P. S. Subramanian, J. Coord. Chem., 66 (2013) 287-299.

[48] N. Lah, G. Giester, P. Šegedin, A. Murn, K. Podlipnik and I. Leban, Acta Cryst., C57 (2001) 546-548.

[49] M. Barquín, M. J. González-Garmendia, L. Larrínaga, E. Pinilla, J. M. Seco and M. R. Torres, J. Coord. Chem., 63 (2010) 1652-1665.

[50] S. Youngme, A. Cheansirisomboon, C. Danvirutai, C. Pakawatchai, N. Chaichit, C. Engkagul, G. A. van Albada, J. S. Costa and J. Reedijk, Polyhedron, 27 (2008) 1875-1882.

[51] T. Kawata, H. Uekusa, T. Furukawa, T. Tokii, Y. Muto, M. Kato and S. Ohba, Acta Crystallogr. Sect. B, 48 (1992) 253-261.

[52] J. E. Huheey, E. A. Keiter and R. L. Keiter, Inorganic chemistry. Principles of Structure and Reactivity, 4th Ed., (1993).

[53] D. Sutton, Electronic Spectra of Transition Metal Complexes, McGraw-Hill, London, UK, (1975).

[54] S. Kumar, R. P. Sharma, P. Venugopalan, V. Singh Gondil, S. Chhibber, T. Aree, M. Witwicki and V. Ferretti, Inorganica Chim. Acta, 1 (2018) 288-297.

[55] R. P. Sharma, A. Saini, S. Kumar, J. Kumar, P. Venugopalan, V. S. Gondil, S. Chhibber and T. Aree, Polyhedron, 123 (2017) 430-440.

[56] N. Wei, N. N. Murthy and K. D. Karlin, Inorg. Chem., 33 (1994) 6093-6100.

[57] L.-L. Han, S.-N. Wang, Z. Jagličić, S.-Y. Zeng, J. Zheng, Z.-H. Li, J.-S. Chen and D. Sun, CrystEngComm, 17 (2015) 1405-1415. 

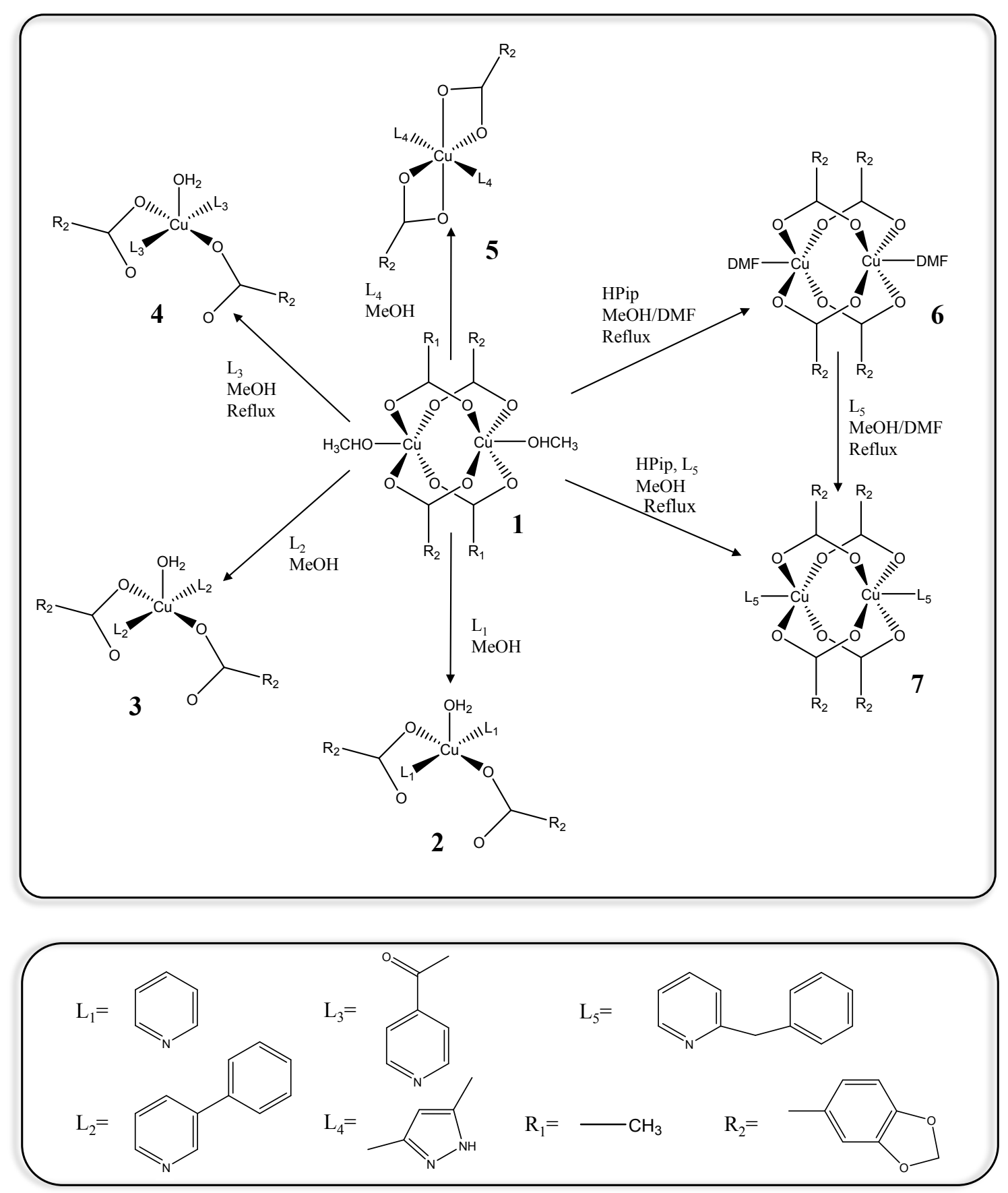

Scheme 1. Schematic synthesis of the compounds 1-7. 
Table 1. Crystallographic data for compounds 2-4.

\begin{tabular}{|c|c|c|c|}
\hline & 2 & 3 & 4 \\
\hline Empirical formula & $\mathrm{C}_{26} \mathrm{H}_{22} \mathrm{CuN}_{2} \mathrm{O}_{9}$ & $\mathrm{C}_{38} \mathrm{H}_{30} \mathrm{CuN}_{2} \mathrm{O}_{9}$ & $\mathrm{C}_{33} \mathrm{H}_{40} \mathrm{CuN}_{2} \mathrm{O}_{15}$ \\
\hline Formula weigh & 569.99 & 722.20 & 768.21 \\
\hline$T(\mathrm{~K})$ & $100(2)$ & $100(2)$ & $100(2)$ \\
\hline Wavelength $(\AA ̊)$ & 0.71073 & 0.71073 & 0.71073 \\
\hline System, space group & Monoclinic, C 2/c & Monoclinic, C 2/c & Monoclinic, C 2/c \\
\hline \multicolumn{4}{|l|}{ Unit cell dimensions } \\
\hline$a(\AA)$ & $15.530(3)$ & $22.6648(13)$ & $23.1610(17)$ \\
\hline$b(\AA)$ & $6.1225(12)$ & $5.7527(3)$ & $5.8928(4)$ \\
\hline$c(\AA)$ & $25.132(5)$ & $23.9870(16)$ & $26.0634(19)$ \\
\hline$a\left(^{\circ}\right)$ & 90 & 90 & 90 \\
\hline$\beta\left(^{\circ}\right)$ & $91.533(6)$ & $95.958(4)$ & $110.439(2)$ \\
\hline$\gamma\left({ }^{\circ}\right)$ & 90 & 90 & 90 \\
\hline$V\left(\AA^{3}\right)$ & $2388.7(8)$ & $3110.6(3)$ & $3333.3(4)$ \\
\hline$Z$ & 4 & 4 & 4 \\
\hline Dcalc $\left(\mathrm{g} \mathrm{cm}^{3}\right)$ & 1.585 & 1.542 & 1.531 \\
\hline$\mu\left(\mathrm{mm}^{-1}\right)$ & 0.975 & 0.767 & 0.733 \\
\hline$F(000)$ & 1172 & 1492 & 1604 \\
\hline Crystal size $\left(\mathrm{mm}^{3}\right)$ & $0.297 \times 0.063 \times 0.062$ & $0.707 \times 0.101 \times 0.038$ & $0.179 \times 0.068 \times 0.032$ \\
\hline hkl ranges & $\begin{array}{l}-17 \leq \mathrm{h} \leq 18 \\
-7 \leq \mathrm{k} \leq 7 \\
-29 \leq 1 \leq 29\end{array}$ & $\begin{array}{l}-29 \leq \mathrm{h} \leq 29 \\
-7 \leq \mathrm{k} \leq 7 \\
-31 \leq 1 \leq 31\end{array}$ & $\begin{array}{l}-23 \leq h \leq 23 \\
-6 \leq k \leq 6 \\
-26 \leq 1 \leq 26\end{array}$ \\
\hline $2 \theta$ range $\left({ }^{\circ}\right)$ & 3.048 to 24.446 & & \\
\hline $\begin{array}{l}\text { Reflections collected/ } \\
\text { unique/[Rint] }\end{array}$ & $\begin{array}{l}8490 / 1953 \quad[R(\text { int })= \\
0.0449]\end{array}$ & $\begin{array}{l}32090 / 3576 \\
{[R(\text { int })=0.1365]}\end{array}$ & $\begin{array}{l}51462 / 1898 \quad[R \text { (int) } \\
=0.0691]\end{array}$ \\
\hline $\begin{array}{l}\text { Completeness to } \theta= \\
25.242^{\circ}\end{array}$ & $99.1 \%$ & $99.9 \%$ & $63.0 \%$ \\
\hline Absorption Correction & Semi-empirical & Semi-empirical & Semi-empirical \\
\hline Max. and min. transmis. & 0.7451 and 0.6333 & 0.7456 and 0.6731 & 0.7446 and 0.6930 \\
\hline Refinement method & $\begin{array}{l}\text { Full matrix least- } \\
\text { squares on } \mathrm{F}^{2}\end{array}$ & $\begin{array}{l}\text { Full matrix least- } \\
\text { squares on } \mathrm{F}^{2}\end{array}$ & $\begin{array}{l}\text { Full matrix least- } \\
\text { squares on } \mathrm{F}^{2}\end{array}$ \\
\hline Data/restrains/parameters & $1953 / 1 / 159$ & $3576 / 0 / 230$ & $1898 / 5 / 222$ \\
\hline Goodness of fit (GOF) on $F^{2}$ & 1.134 & 1.056 & 1.084 \\
\hline Final $R$ indices $[I>2 \sigma(I)]$ & $\begin{array}{l}R 1=0.0853 \\
w R 2=0.2283\end{array}$ & $\begin{array}{l}R 1=0.0518 \\
w R 2=0.0960\end{array}$ & $\begin{array}{l}R 1=0.0675 \\
w R 2=0.1757\end{array}$ \\
\hline$R$ indices (all data) & $\begin{array}{l}R 1=0.0916, \\
W R 2=0.2320\end{array}$ & $\begin{array}{l}R 1=0.0849 \\
W R 2=0.1073\end{array}$ & $\begin{array}{l}R 1=0.0735 \\
W R 2=0.1813\end{array}$ \\
\hline Extinction coefficient & $\mathrm{n} / \mathrm{a}$ & $\mathrm{n} / \mathrm{a}$ & $\mathrm{n} / \mathrm{a}$ \\
\hline $\begin{array}{l}\text { Largest. Diff. peak and hole } \\
\left(\mathrm{e} \AA^{-3}\right)\end{array}$ & 2.324 and -1.830 & 0.423 and -0.661 & 1.623 and -0.761 \\
\hline
\end{tabular}


Table 2. Crystallographic data for compounds 5-7.

\begin{tabular}{|c|c|c|c|}
\hline & 5 & 6 & 7 \\
\hline Empirical formula & $\mathrm{C}_{26} \mathrm{H}_{26} \mathrm{CuN}_{4} \mathrm{O}_{8}$ & $\mathrm{C}_{44} \mathrm{H}_{48} \mathrm{Cu}_{2} \mathrm{~N}_{4} \mathrm{O}_{20}$ & $\mathrm{C}_{56} \mathrm{H}_{42} \mathrm{Cu}_{2} \mathrm{~N}_{2} \mathrm{O}_{16}$ \\
\hline Formula weigh & 586.05 & 1079.94 & 1125.99 \\
\hline$T(\mathrm{~K})$ & $100(2)$ & $100(2)$ & $100(2)$ \\
\hline Wavelength $(\AA)$ & 0.71073 & 0.71073 & 0.71073 \\
\hline System, space group & Triclinic, $\mathrm{P}-1$ & Triclinic, P-1 & Monoclinic, P21/c \\
\hline \multicolumn{4}{|l|}{ Unit cell dimensions } \\
\hline$a(\AA)$ & $6.0789(2)$ & 10.4359(5) & 17.0709(6) \\
\hline$b(\AA)$ & $12.4827(4)$ & $11.1697(5)$ & $18.5452(7)$ \\
\hline$c(\AA)$ & $17.7198(6)$ & 12.1119(6) & $15.3980(5)$ \\
\hline$a\left(^{\circ}\right)$ & $73.0490(10)$ & $87.276(2)$ & 90 \\
\hline$\beta\left(^{\circ}\right)$ & $83.9550(10)$ & $65.220(2)$ & $99.8320(10)$ \\
\hline$\gamma\left(^{\circ}\right)$ & $86.468(2)$ & $64.078(2)$ & 90 \\
\hline $\mathrm{V}\left(\AA^{3}\right)$ & $1278.35(7)$ & $1136.84(10)$ & $4803.2(3)$ \\
\hline$Z$ & 2 & 1 & 4 \\
\hline Dcalc $\left(\mathrm{g} \mathrm{cm}^{3}\right)$ & 1.523 & 1.577 & 1.557 \\
\hline$\mu\left(\mathrm{mm}^{-1}\right)$ & 0.913 & 1.023 & 0.965 \\
\hline$F(000)$ & 606 & 558 & 2312 \\
\hline Crystal size $\left(\mathrm{mm}^{3}\right)$ & $0.236 \times 0.138 \times 0.081$ & $0.233 \times 0.158 \times 0.155$ & $0.278 \times 0.082 \times 0.045$ \\
\hline hkl ranges & $\begin{array}{l}-7 \leq h \leq 7 \\
-15 \leq k \leq 15 \\
-22 \leq 1 \leq 22\end{array}$ & $\begin{array}{l}-14 \leq h \leq 13 \\
-15 \leq k \leq 15 \\
-17 \leq 1 \leq 17\end{array}$ & $\begin{array}{l}-22 \leq h \leq 22 \\
-24 \leq k \leq 24 \\
-20 \leq 1 \leq 20\end{array}$ \\
\hline $2 \theta$ range $\left(^{\circ}\right)$ & 2.413 to 26.728 & 2.421 to 30.557 & 2.422 to 28.332 \\
\hline $\begin{array}{l}\text { Reflections collected/ } \\
\text { unique/[Rint] }\end{array}$ & $\begin{array}{l}29716 / 5397[R(\text { int })= \\
0.0345]\end{array}$ & $\begin{array}{l}46461 / 6939[\mathrm{R}(\text { int })= \\
0.0305]\end{array}$ & $\begin{array}{l}122091 / 11916 \text { [R(int) } \\
=0.0495]\end{array}$ \\
\hline $\begin{array}{l}\text { Completeness to } \theta= \\
25.242^{\circ}\end{array}$ & $99.6 \%$ & $99.7 \%$ & $99.4 \%$ \\
\hline Absorption Correction & Semi-empirical & Semi-empirical & Semi-empirical \\
\hline 0.7454 and 0.6940 & 0.7454 and 0.6940 & 0.7461 and 0.6897 & 0.7457 and 0.06985 \\
\hline Refinement method & $\begin{array}{l}\text { Full matrix least- } \\
\text { squares on } \mathrm{F}^{2}\end{array}$ & $\begin{array}{l}\text { Full matrix least- } \\
\text { squares on } \mathrm{F}^{2}\end{array}$ & $\begin{array}{l}\text { Full matrix least- } \\
\text { squares on } \mathrm{F}^{2}\end{array}$ \\
\hline Data/restrains/parameters & $5397 / 0 / 359$ & $6939 / 0 / 317$ & $11916 / 1 / 685$ \\
\hline Goodness of fit (GOF) on $F^{2}$ & 1.020 & 1.036 & 1.048 \\
\hline Final $R$ indices $[1>2 \sigma(I)]$ & $\begin{array}{l}R 1=0.0293 \\
W R 2=0.0714\end{array}$ & $\begin{array}{l}R 1=0.0427 \\
w R 2=0.1060\end{array}$ & $\begin{array}{l}R 1=0.0359 \\
W R 2=0.0893\end{array}$ \\
\hline$R$ indices (all data) & $\begin{array}{l}\text { R1 }=0.0384 \\
W R 2=0.0761\end{array}$ & $\begin{array}{l}\text { R1 }=0.0516 \\
W R 2=0.1119\end{array}$ & $\begin{array}{l}R 1=0.0488 \\
W R 2=0.0976\end{array}$ \\
\hline Extinction coefficient & $\mathrm{n} / \mathrm{a}$ & $\mathrm{n} / \mathrm{a}$ & $\mathrm{n} / \mathrm{a}$ \\
\hline $\begin{array}{l}\text { Largest. Diff. peak and hole } \\
\left(\mathrm{e} \AA^{-3}\right)\end{array}$ & 0.464 and -0.419 & 1.480 and -1.465 & 0.623 and -0.567 \\
\hline
\end{tabular}


Table 3. Selected bond lengths ( $(\AA)$ and bond angles $\left({ }^{\circ}\right)$ for compounds 2 - 4 a.

\begin{tabular}{|c|c|c|c|}
\hline 2 & & & \\
\hline Bond length ( $(\AA)$ & & & \\
\hline $\mathrm{Cu}(1)-\mathrm{O}(1)$ & $1.937(5)$ & $\mathrm{Cu}(1)-\mathrm{N}(1)$ & $2.018(6)$ \\
\hline $\mathrm{Cu}(1)-\mathrm{O}(1) \# 1$ & $1.937(5)$ & $\mathrm{Cu}(1)-\mathrm{N}(1) \# 1$ & $2.017(6)$ \\
\hline $\mathrm{Cu}(1)-\mathrm{O}(5)$ & $2.282(9)$ & & \\
\hline Bond angles $\left({ }^{\circ}\right)$ & & & \\
\hline $\mathrm{O}(1) \# 1-\mathrm{Cu}(1)-\mathrm{O}(1)$ & $177.7(3)$ & $\mathrm{O}(1) \# 1-\mathrm{Cu}(1)-\mathrm{N}(1) \# 1$ & $90.5(2)$ \\
\hline $\mathrm{O}(1) \# 1-\mathrm{Cu}(1)-\mathrm{O}(5)$ & $88.86(16)$ & $\mathrm{N}(1) \# 1-\mathrm{Cu}(1)-\mathrm{O}(5)$ & $97.3(2)$ \\
\hline $\mathrm{O}(1) \# 1-\mathrm{Cu}(1)-\mathrm{N}(1)$ & $89.8(2)$ & $N(1)-C u(1)-N(1) \# 1$ & $165.5(4)$ \\
\hline $\mathrm{O}(1) \# 1-\mathrm{Cu}(1)-\mathrm{O}(5)$ & $88.86(16)$ & & \\
\hline 3 & & & \\
\hline Bond length $(\AA)$ & & & \\
\hline $\mathrm{Cu}(1)-\mathrm{O}(1)$ & $1.9379(19)$ & $\mathrm{Cu}(1)-\mathrm{N}(1)$ & $2.020(2)$ \\
\hline $\mathrm{Cu}(1)-\mathrm{O}(1) \# 1$ & $1.9380(19)$ & $\mathrm{Cu}(1)-\mathrm{N}(1) \# 1$ & $2.020(2)$ \\
\hline $\mathrm{Cu}(1)-\mathrm{O}(5)$ & $2.241(3)$ & & \\
\hline Bond angles $\left({ }^{\circ}\right)$ & & & \\
\hline $\mathrm{O}(1)-\mathrm{Cu}(1)-\mathrm{O}(1) \# 1$ & 176.06(14) & $\mathrm{O}(1)-\mathrm{Cu}(1)-\mathrm{O}(5)$ & $88.03(7)$ \\
\hline $\mathrm{O}(1)-\mathrm{Cu}(1)-\mathrm{N}(1)$ & 91.72(9) & $\mathrm{N}(1)-\mathrm{Cu}(1)-\mathrm{O}(5)$ & $93.62(8)$ \\
\hline $\mathrm{O}(1) \# 1-\mathrm{Cu}(1)-\mathrm{N}(1)$ & $88.53(9)$ & $\mathrm{N}(1) \# 1-\mathrm{Cu}(1)-\mathrm{O}(5)$ & $93.62(8)$ \\
\hline$N(1)-C u(1)-N(1) \# 1$ & $172.77(15)$ & & \\
\hline $4 a$ & & & \\
\hline Bond length ( $(\AA)$ & & & \\
\hline $\mathrm{Cu}(1)-\mathrm{O}(1)$ & $1.928(4)$ & $\mathrm{Cu}(1)-\mathrm{N}(1)$ & $2.023(5)$ \\
\hline $\mathrm{Cu}(1)-\mathrm{O}(1) \# 1$ & $1.928(4)$ & $\mathrm{Cu}(1)-\mathrm{N}(1) \# 1$ & $2.023(5)$ \\
\hline $\mathrm{Cu}(1)-\mathrm{O}(5 \mathrm{~W})$ & $2.266(6)$ & & \\
\hline Bond angles $\left({ }^{\circ}\right)$ & & & \\
\hline $\mathrm{O}(1)-\mathrm{Cu}(1)-\mathrm{O}(1) \# 1$ & $174.9(3)$ & $\mathrm{O}(1)-\mathrm{Cu}(1)-\mathrm{O}(5 \mathrm{~W})$ & $87.47(13)$ \\
\hline $\mathrm{O}(1) \# 1-\mathrm{Cu}(1)-\mathrm{N}(1) \# 1$ & 91.64(18) & $\mathrm{N}(1) \# 1-\mathrm{Cu}(1)-\mathrm{O}(5 \mathrm{~W})$ & $95.92(15)$ \\
\hline $\mathrm{O}(1) \# 1-\mathrm{Cu}(1)-\mathrm{N}(1)$ & $88.88(18)$ & $N(1)-C u(1)-N(1) \# 1$ & 168.2(3) \\
\hline
\end{tabular}

2: \#1 -x+1,y,-z+3/2; 3: \#1 -x+1,y,-z+1/2; 4: \#1-x+1,y,-z+1/2; 
Table 4. Selected bond lengths $(\AA)$ and bond angles $\left({ }^{\circ}\right)$ for compound 5.

\begin{tabular}{|c|c|c|c|}
\hline 5 & & & \\
\hline Bond length (Å) & & & \\
\hline $\mathrm{Cu}(1 \mathrm{~A})-\mathrm{O}(1 \mathrm{~A}) \# 1$ & $1.9654(12)$ & $\mathrm{Cu}(1 \mathrm{~B})-\mathrm{O}(1 \mathrm{~B}) \# 2$ & $1.9672(12)$ \\
\hline $\mathrm{Cu}(1 \mathrm{~A})-\mathrm{O}(2 \mathrm{~A})$ & $2.6536(14)$ & $\mathrm{Cu}(1 \mathrm{~B})-\mathrm{O}(2 \mathrm{~B})$ & $2.6138(14)$ \\
\hline $\mathrm{Cu}(1 \mathrm{~A})-\mathrm{N}(1 \mathrm{~A}) \# 1$ & $1.9749(15)$ & $\mathrm{Cu}(1 \mathrm{~B})-\mathrm{N}(1 \mathrm{~B}) \# 2$ & $1.9769(15)$ \\
\hline Bond angles $\left({ }^{\circ}\right)$ & & & \\
\hline $\mathrm{O}(1 \mathrm{~A}) \# 1-\mathrm{Cu}(1 \mathrm{~A})-\mathrm{O}(1 \mathrm{~A})$ & 180 & $\mathrm{O}(1 \mathrm{~B}) \# 2-\mathrm{Cu}(1 \mathrm{~B})-\mathrm{O}(1 \mathrm{~B})$ & 180 \\
\hline $\mathrm{O}(1 \mathrm{~A}) \# 1-\mathrm{Cu}(1 \mathrm{~A})-\mathrm{N}(1 \mathrm{~A})$ & $89.78(6)$ & $\mathrm{O}(1 \mathrm{~B}) \# 2-\mathrm{Cu}(1 \mathrm{~B})-\mathrm{N}(1 \mathrm{~B})$ & $89.74(6)$ \\
\hline $\mathrm{O}(1 \mathrm{~A}) \# 1-\mathrm{Cu}(1 \mathrm{~A})-\mathrm{N}(1 \mathrm{~A}) \# 1$ & $90.22(6)$ & $\mathrm{O}(1 \mathrm{~B}) \# 2-\mathrm{Cu}(1 \mathrm{~B})-\mathrm{N}(1 \mathrm{~B}) \# 2$ & $90.26(6)$ \\
\hline$N(1 A)-C u(1 A)-N(1 A) \# 1$ & 180 & $\mathrm{~N}(1 \mathrm{~B})-\mathrm{Cu}(1 \mathrm{~B})-\mathrm{N}(1 \mathrm{~B}) \# 2$ & 180 \\
\hline
\end{tabular}

5: \#1-x,-y,-z+1 \#2-x+2,-y+1,-z+2 
Table 5. Selected intermolecular interactions for compounds 2-5.

\begin{tabular}{|c|c|c|c|c|}
\hline 2 & $H \cdots A(\AA)$ & $D \cdots A(\AA)$ & D-H (Å) & $>D-H \cdots A\left({ }^{\circ}\right)$ \\
\hline $\mathrm{O} 5-\mathrm{H} 5 \mathrm{O} \cdots \mathrm{O} 2$ & $1.90(15)$ & $2.802(8)$ & $0.92(12)$ & $167(18)$ \\
\hline $\mathrm{C} 9-\mathrm{H} 9 \cdots \mathrm{O} 4$ & $2.325(8)$ & $3.253(15)$ & 0.9500 & $166(18)$ \\
\hline \multicolumn{5}{|l|}{3} \\
\hline $\mathrm{O} 5-\mathrm{H} 5 \mathrm{O} \cdots \mathrm{O} 2$ & $1.87(2)$ & $2.711(3)$ & $0.85(3)$ & $170(3)$ \\
\hline \multicolumn{5}{|l|}{$4 a$} \\
\hline $\mathrm{O} 5 \mathrm{~W}-\mathrm{H} 5 \mathrm{~W} \cdots \mathrm{O} 2$ & $1.967(8)$ & $2.765(13)$ & $0.804(10)$ & $171.62(14)$ \\
\hline $\mathrm{C} 15-\mathrm{H} 15 \mathrm{~B} \cdots \mathrm{O} 3$ & $2.470(12)$ & $3.433(14)$ & $0.9800(12)$ & $167.74(14)$ \\
\hline \multicolumn{5}{|l|}{5} \\
\hline $\mathrm{N} 2 \mathrm{~A}-\mathrm{H} 2 \mathrm{~A} \cdots \mathrm{O} 2 \mathrm{~A}$ & $1.940(14)$ & $2.7588(12)$ & $0.8800(14)$ & $154.10(15)$ \\
\hline $\mathrm{N} 2 \mathrm{~B}-\mathrm{H} 2 \mathrm{~B} \cdots \mathrm{O} 2 \mathrm{~B}$ & $1.977(14)$ & $2.7615(12)$ & $0.8800(14)$ & $147.76(15)$ \\
\hline
\end{tabular}


Table 6 . Selected bond lengths $(\AA)$ and bond angles $\left({ }^{\circ}\right)$ for compounds 6 and 7 .

\begin{tabular}{|c|c|c|c|}
\hline 6 & & & \\
\hline Bond length $(\AA)$ & & & \\
\hline $\mathrm{Cu}(1)-\mathrm{O}(5) \# 1$ & $1.9633(14)$ & $\mathrm{Cu}(1)-\mathrm{O}(2) \# 1$ & $1.9727(13)$ \\
\hline $\mathrm{Cu}(1)-\mathrm{O}(1)$ & $1.9669(13)$ & $\mathrm{Cu}(1)-\mathrm{O}(9)$ & $2.1540(15)$ \\
\hline $\mathrm{Cu}(1)-\mathrm{O}(6)$ & $1.9695(14)$ & $\mathrm{Cu} \cdots \mathrm{Cu}$ & $2.6057(5)$ \\
\hline Bond angles $\left({ }^{\circ}\right)$ & & & \\
\hline $\mathrm{O}(5) \# 1-\mathrm{Cu}(1)-\mathrm{O}(1)$ & $88.98(6)$ & $\mathrm{O}(6)-\mathrm{Cu}(1)-\mathrm{O}(9)$ & $92.64(6)$ \\
\hline $\mathrm{O}(5) \# 1-\mathrm{Cu}(1)-\mathrm{O}(6)$ & $169.37(6)$ & $\mathrm{O}(2) \# 1-\mathrm{Cu}(1)-\mathrm{O}(9)$ & $95.08(6)$ \\
\hline $\mathrm{O}(1)-\mathrm{Cu}(1)-\mathrm{O}(6)$ & $91.69(6)$ & $\mathrm{O}(5) \# 1-\mathrm{Cu}(1)-\mathrm{Cu}(1) \# 1$ & $89.85(5)$ \\
\hline $\mathrm{O}(5) \# 1-\mathrm{Cu}(1)-\mathrm{O}(2) \# 1$ & $88.44(6)$ & $\mathrm{O}(1)-\mathrm{Cu}(1)-\mathrm{Cu}(1) \# 1$ & $83.70(4)$ \\
\hline $\mathrm{O}(1)-\mathrm{Cu}(1)-\mathrm{O}(2) \# 1$ & $169.17(6)$ & $\mathrm{O}(6)-\mathrm{Cu}(1)-\mathrm{Cu}(1) \# 1$ & $79.68(4)$ \\
\hline $\mathrm{O}(6)-\mathrm{Cu}(1)-\mathrm{O}(2) \# 1$ & $88.94(6)$ & $\mathrm{O}(2) \# 1-\mathrm{Cu}(1)-\mathrm{Cu}(1) \# 1$ & $85.78(4)$ \\
\hline $\mathrm{O}(5) \# 1-\mathrm{Cu}(1)-\mathrm{O}(9)$ & $97.86(6)$ & $\mathrm{O}(9)-\mathrm{Cu}(1)-\mathrm{Cu}(1) \# 1$ & $172.26(5)$ \\
\hline $\mathrm{O}(1)-\mathrm{Cu}(1)-\mathrm{O}(9)$ & $95.69(6)$ & & \\
\hline 7 & & & \\
\hline Bond length $(\AA ̊)$ & & & \\
\hline $\mathrm{Cu}(1)-\mathrm{O}(6)$ & $1.9516(14)$ & $\mathrm{Cu}(2)-\mathrm{O}(13)$ & $1.9598(14)$ \\
\hline $\mathrm{Cu}(1)-\mathrm{O}(14)$ & $1.9588(14)$ & $\mathrm{Cu}(2)-\mathrm{O}(5)$ & $1.9722(14)$ \\
\hline $\mathrm{Cu}(1)-\mathrm{O}(2)$ & $1.9731(14)$ & $\mathrm{Cu}(2)-\mathrm{O}(9)$ & $1.9773(14)$ \\
\hline $\mathrm{Cu}(1)-\mathrm{O}(10)$ & $1.9785(14)$ & $\mathrm{Cu}(2)-\mathrm{O}(1)$ & $1.9835(14)$ \\
\hline $\mathrm{Cu}(1)-\mathrm{N}(1)$ & $2.1999(16)$ & $\mathrm{Cu}(2)-\mathrm{N}(2)$ & $2.2484(16)$ \\
\hline & & $\mathrm{Cu}(1) \cdots \mathrm{Cu}(2)$ & $2.6910(3)$ \\
\hline Bond angle $\left({ }^{\circ}\right)$ & & & \\
\hline $\mathrm{O}(6)-\mathrm{Cu}(1)-\mathrm{O}(14)$ & $166.18(6)$ & $\mathrm{O}(13)-\mathrm{Cu}(2)-\mathrm{O}(5)$ & $167.61(6)$ \\
\hline $\mathrm{O}(6)-\mathrm{Cu}(1)-\mathrm{O}(2)$ & $89.11(7)$ & $\mathrm{O}(13)-\mathrm{Cu}(2)-\mathrm{O}(9)$ & $87.99(6)$ \\
\hline $\mathrm{O}(14)-\mathrm{Cu}(1)-\mathrm{O}(2)$ & $88.84(7)$ & $\mathrm{O}(5)-\mathrm{Cu}(2)-\mathrm{O}(9)$ & $91.71(6)$ \\
\hline $\mathrm{O}(6)-\mathrm{Cu}(1)-\mathrm{O}(10)$ & $90.28(6)$ & $\mathrm{O}(13)-\mathrm{Cu}(2)-\mathrm{O}(1)$ & $88.68(7)$ \\
\hline $\mathrm{O}(14)-\mathrm{Cu}(1)-\mathrm{O}(10)$ & $88.87(7)$ & $\mathrm{O}(5)-\mathrm{Cu}(2)-\mathrm{O}(1)$ & $88.51(6)$ \\
\hline $\mathrm{O}(2)-\mathrm{Cu}(1)-\mathrm{O}(10)$ & $167.89(6)$ & $\mathrm{O}(9)-\mathrm{Cu}(2)-\mathrm{O}(1)$ & $165.36(6)$ \\
\hline $\mathrm{O}(6)-\mathrm{Cu}(1)-\mathrm{N}(1)$ & $95.73(6)$ & $\mathrm{O}(13)-\mathrm{Cu}(2)-\mathrm{N}(2)$ & $99.01(6)$ \\
\hline $\mathrm{O}(14)-\mathrm{Cu}(1)-\mathrm{N}(1)$ & $98.08(6)$ & $\mathrm{O}(5)-\mathrm{Cu}(2)-\mathrm{N}(2)$ & $93.11(6)$ \\
\hline $\mathrm{O}(2)-\mathrm{Cu}(1)-\mathrm{N}(1)$ & $101.49(6)$ & $\mathrm{O}(9)-\mathrm{Cu}(2)-\mathrm{N}(2)$ & $103.37(6)$ \\
\hline $\mathrm{O}(10)-\mathrm{Cu}(1)-\mathrm{N}(1)$ & $90.60(6)$ & $\mathrm{O}(1)-\mathrm{Cu}(2)-\mathrm{N}(2)$ & $91.23(6)$ \\
\hline
\end{tabular}

6: \#1-x+2,-y,-z+1 
Table 7. UV-Vis spectroscopy data of compounds 1-7 and similar examples of the literature.

\begin{tabular}{|l|c|c|c|c|}
\hline \multicolumn{1}{|c|}{ Compound } & Geometry & $\lambda_{\text {max }}(\mathbf{n m})$ & $\boldsymbol{\varepsilon}\left(\mathbf{M}^{-1} \mathbf{c m}^{-1}\right)$ & Ref. \\
\hline$\left[\mathrm{Cu}(\right.$ dien $\left.)(\mathrm{pnb})_{2}\right] \cdot \mathrm{H}_{2} \mathrm{O}$ & sqp & 615 & 194 & {$[54]$} \\
\hline$\left[\mathrm{Cu}(\text { dien })_{2}\right](\mathrm{pnb})_{2}$ & Oh & 618 & 120 & {$[54]$} \\
\hline$\left[\mathrm{Cu}(\right.$ dien $\left.)(\mathrm{pnb})\left(\mathrm{H}_{2} \mathrm{O}\right)\right] \cdot(\mathrm{pnb}) \cdot(\mathrm{Hpnb})$ & sqp & 608 & 140 & {$[54]$} \\
\hline$\left[\mathrm{Cu}(\mathrm{en})_{2}\left(\mathrm{H}_{2} \mathrm{O}\right)_{2}\right] \cdot(2-\mathrm{PBA})_{2} \cdot 2 \mathrm{H}_{2} \mathrm{O}$ & Oh & 546 & - & {$[55]$} \\
\hline$\left[\mathrm{Cu}(\mathrm{en})_{2}\left(\mathrm{H}_{2} \mathrm{O}\right)\right] \cdot(\mathrm{DPA})_{2} \cdot 3 \mathrm{H}_{2} \mathrm{O}$ & sqp & 535 & - & {$[55]$} \\
\hline$[\mathrm{TMpA}) \mathrm{CuCl}]^{+}$ & bpt & 725 & 90 & {$[56]$} \\
\hline$[(\mathrm{BPQA}) \mathrm{CuCl}]^{+}$ & sqp & 700 & 106 & {$[56]$} \\
\hline$[(\mathrm{BQPA}) \mathrm{CuCl}]^{+}$ & sqp & 737 & 137 & {$[56]$} \\
\hline$[(\mathrm{TMQA}) \mathrm{CuC}]^{+}$ & sqp & 691 & 185 & {$[56]$} \\
\hline$[\mathrm{Cu}(\mu-\mathrm{Pip})(\mu-\mathrm{Ac})(\mathrm{MeOH})]_{2}(\mathbf{1})$ & sqp & 716 & 124 & {$[18]$} \\
\hline$\left[\mathrm{Cu}(\mathrm{Pip})_{2}(\mathrm{py})_{2}\left(\mathrm{H}_{2} \mathrm{O}\right)\right](2)$ & sqp & 710 & 33 & work \\
\hline$\left[\mathrm{Cu}(\mathrm{Pip})_{2}(3-\mathrm{Phpy})_{2}\left(\mathrm{H}_{2} \mathrm{O}\right)\right](3)$ & sqp & 727 & 78 & work \\
\hline$\left[\mathrm{Cu}(\mathrm{Pip})_{2}(4-\mathrm{Acpy})_{2}\left(\mathrm{H}_{2} \mathrm{O}\right)\right](4)$ & sqp & 677 & 68 & work \\
\hline$\left[\mathrm{Cu}(\mathrm{Pip})_{2}(3,5-\mathrm{dmpz})_{2}\right](5)$ & Oh & 714 & 13 & work \\
\hline$\left[\mathrm{Cu}(\mu-\mathrm{Pip})_{2}(\mathrm{DMF})\right] \cdot 2 \mathrm{DMF}(6)$ & sqp & 717 & 76 & work \\
\hline$\left[\mathrm{Cu}(\mu-\mathrm{Pip})_{2}(2-\mathrm{Bzpy})\right](\mathbf{7})$ & sqp & 689 & 86 & work \\
\hline
\end{tabular}

dien= diethylenetriamine; $\mathrm{Hpnb}=\mathrm{p}$-nitrobenzoic acid; en= ethylenediamine; $\mathrm{PBA}=$ phenoxybenzoate; $\mathrm{DPA}=$ diphenylacetate; $\mathrm{TMpA}==\operatorname{tris}[((2-\mathrm{pyridyl})$ methyl) $]$ - methylamine; $B P Q A=1-($ pyridin-2-yl)-N-(pyridin-2-ylmethyl)- $N$-(quinolin-2-ylmethyl)methanamine; BQPA= 1(pyridin-2-yl)-N,N-bis(quinolin-2-ylmethyl)methanamine; TMQA= 1-(isoquinolin-3-yl)-N,Nbis(quinolin-2-ylmethyl)methanamine. bpt = trigonal-bipyramidal; sqp = square-pyramidal; Oh $=$ octahedral 


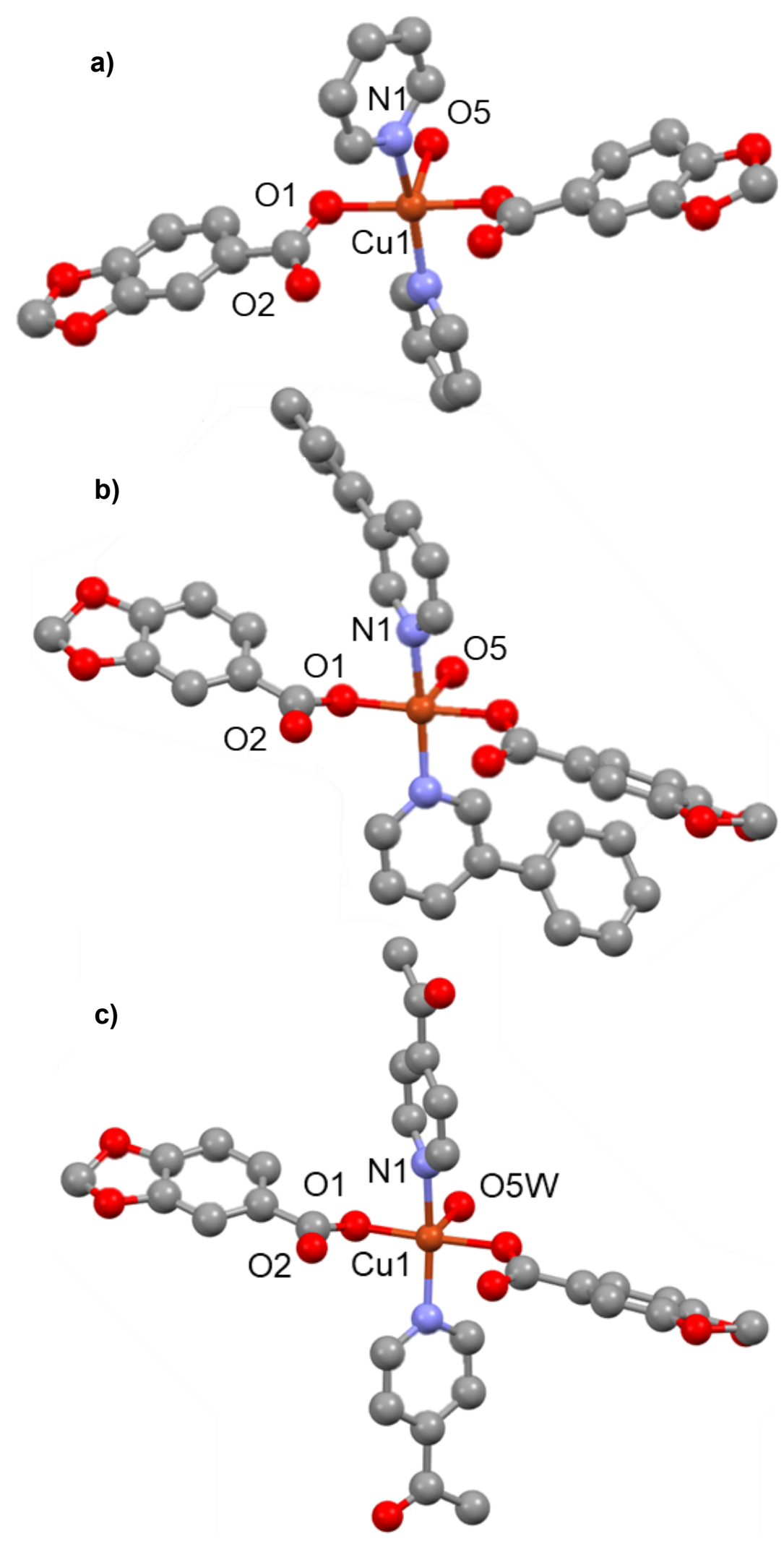

Figure 1. Molecular structure of $\left[\mathrm{Cu}(\mathrm{Pip})_{2}(\mathrm{dPy})_{2}\left(\mathrm{H}_{2} \mathrm{O}\right)\right]$ (a dPy=py (2); b 3-Phpy (3); c 4-Acpy (4a)) complexes showing an atom labelling scheme. The hydrogen atoms are omitted for clarity. 
a)
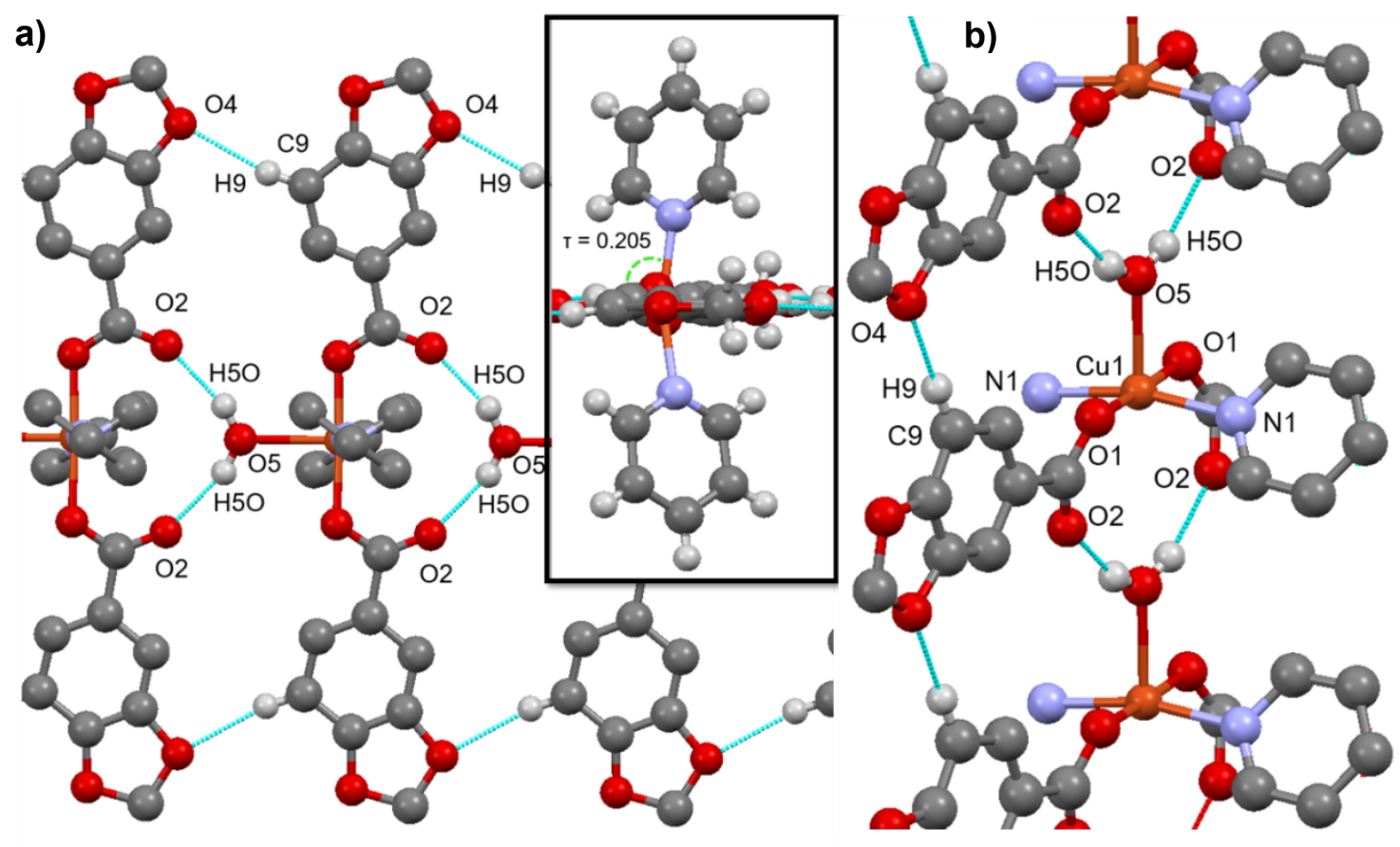

Figure 2. a. $a$ axis view of the one-dimensional ordering of the $\left[\mathrm{Cu}(\mathrm{Pip})_{2}(\mathrm{py})_{2}\left(\mathrm{H}_{2} \mathrm{O}\right)\right](2)$ complex by water-carboxylate hydrogen bonding through the $b$ axis. b. Piperonylate ligands stacked in a row disposition allows its intermolecular $\mathrm{C}-\mathrm{H} \cdots \mathrm{O}$ hydrogen bonding interactions. 

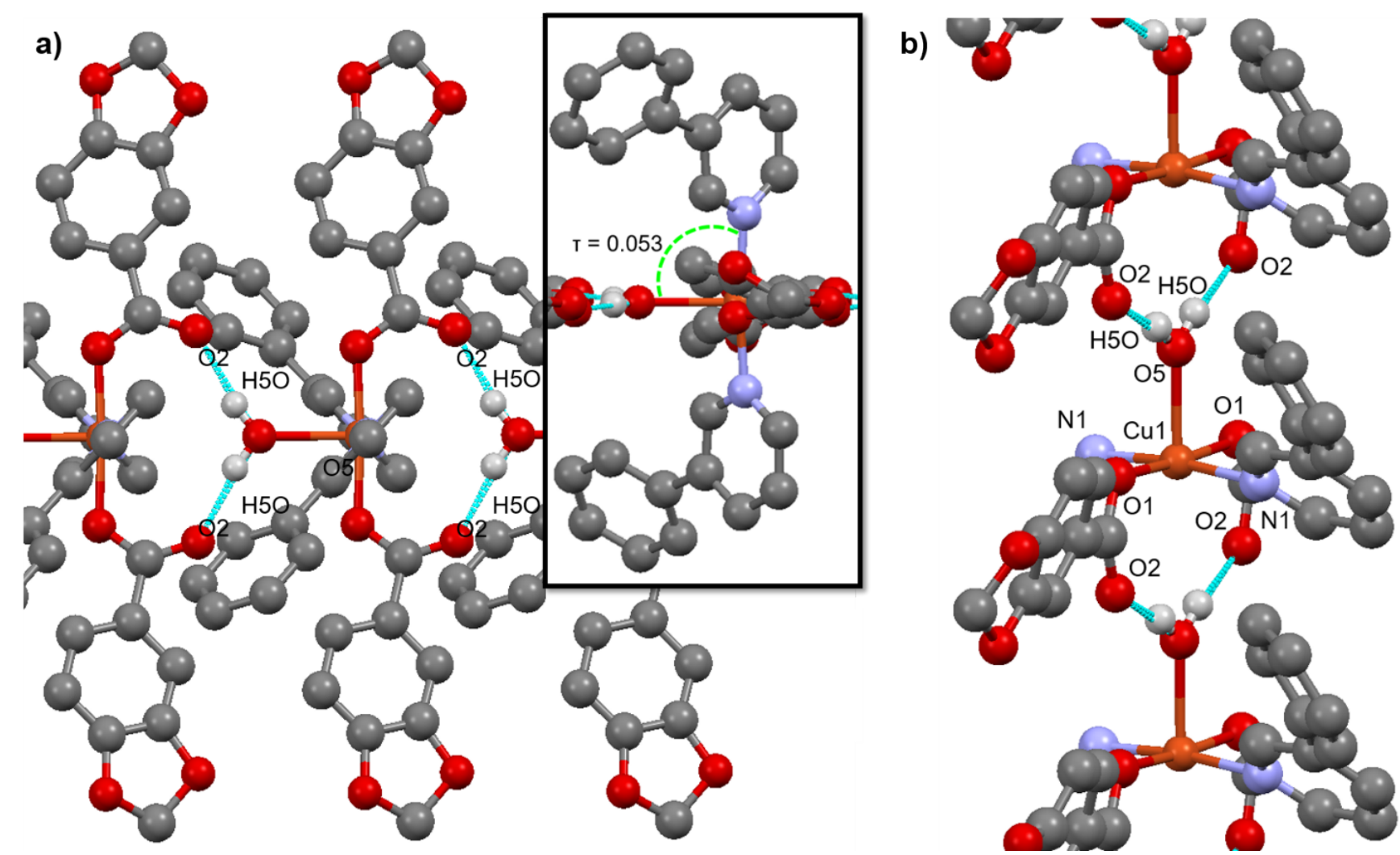

Figure 3. a. $a$ axis view of the one-dimensional ordering of the $\left[\mathrm{Cu}(\mathrm{Pip})_{2}(3-\mathrm{Phpy})_{2}\left(\mathrm{H}_{2} \mathrm{O}\right)\right](3)$ complex by water-carboxylate hydrogen bonding through the $b$ axis. b. Piperonylates planarity drifting disposition prevent its intermolecular $\mathrm{C}-\mathrm{H} \cdots \mathrm{O}$ hydrogen bonding. Only hydrogens involved in the intermolecular interaction are shown. 


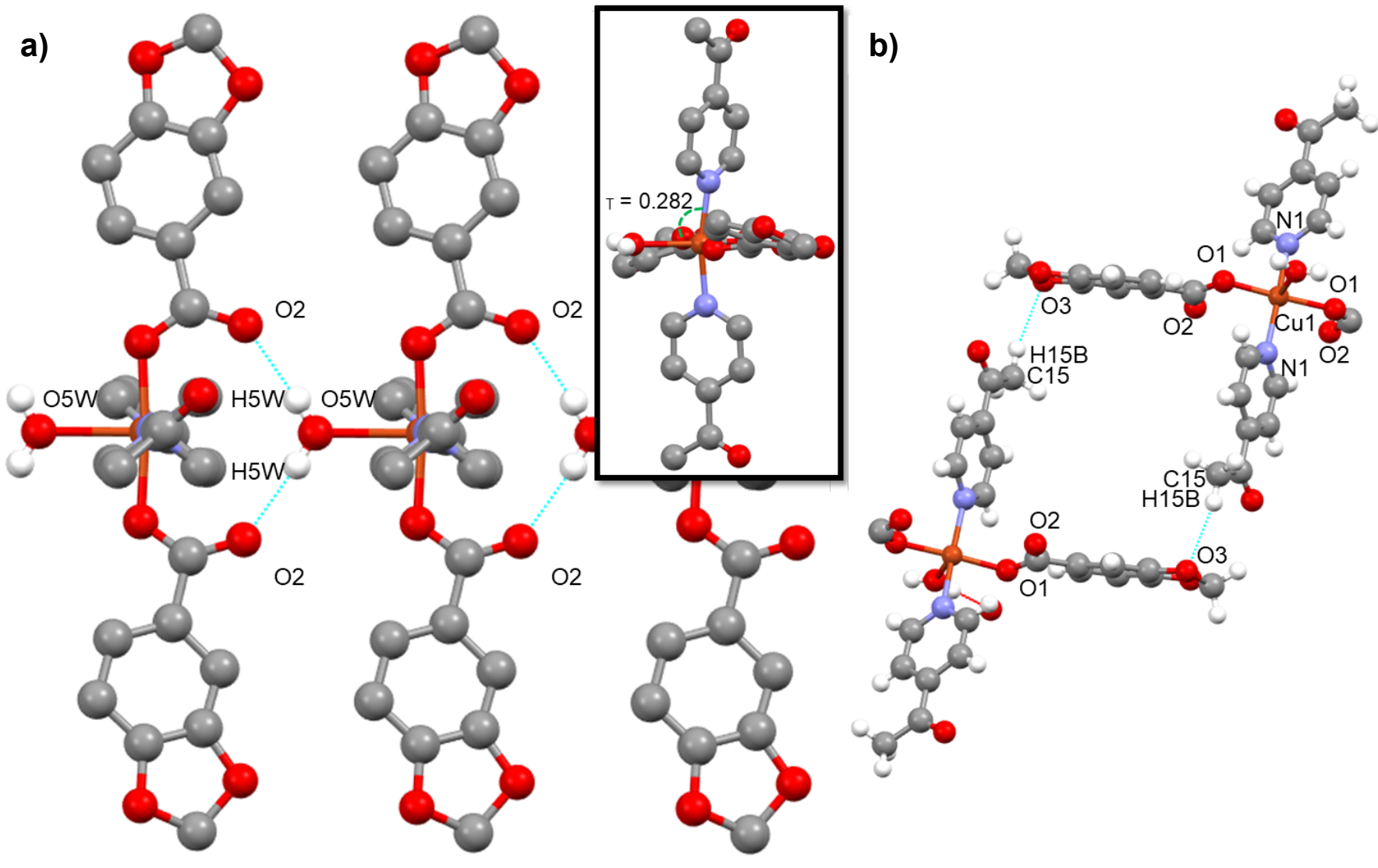

Figure 4. a. $a$ axis view of the one-dimensional ordering of the $\left[\mathrm{Cu}(\mathrm{Pip})_{2}(4-\right.$ Acpy $\left.)_{2}\left(\mathrm{H}_{2} \mathrm{O}\right)\right] \cdot 3 \mathrm{MeOH} \cdot \mathrm{H}_{2} \mathrm{O}(4 \mathrm{a})$ complex by water-carboxylate hydrogen bonding through the $b$ axis. $\mathbf{b}$. $b$ axis view of the propagation through the $b c$ plane by hydrogen bonding between the oxygen of the piperonylate units and the protons of the acetyl groups. Solvent molecules are omitted for clarity. 

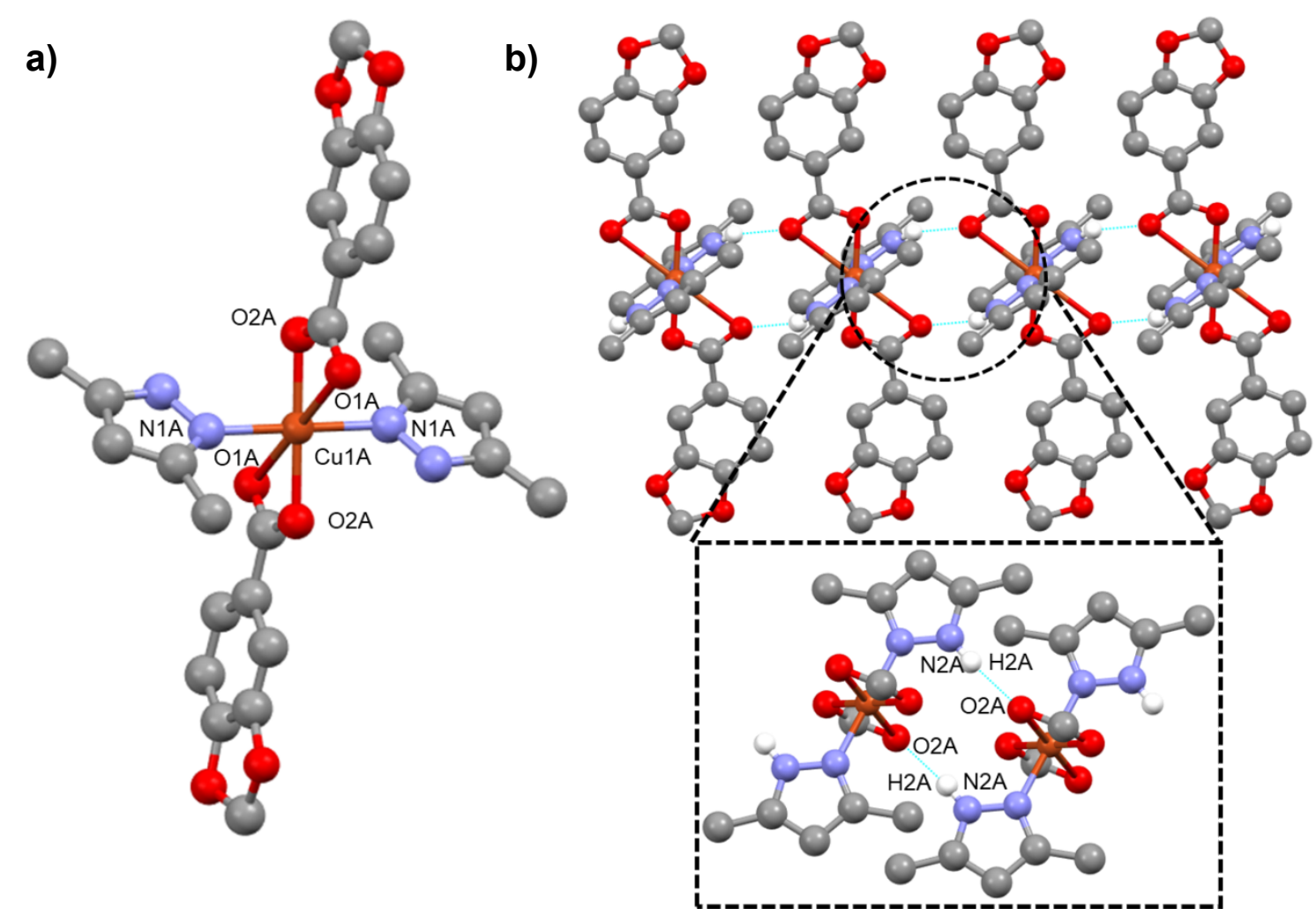

Figure 5. a. Molecular structure of $\left[\mathrm{Cu}(\mathrm{Pip})_{2}(3,5-\mathrm{dmpz})_{2}\right](5)$ complex showing an atom labelling scheme. The hydrogen atoms are omitted for clarity. b. $b$ axis view of the one-dimensional ordering of the $\left[\mathrm{Cu}(\mathrm{Pip})_{2}(3,5-\mathrm{dmpz})_{2}\right](5)$ complex by a double pirazole-carboxylate hydrogen bonding forming 1D chains. Only hydrogen atoms involved in the intermolecular interactions are shown. 
a)

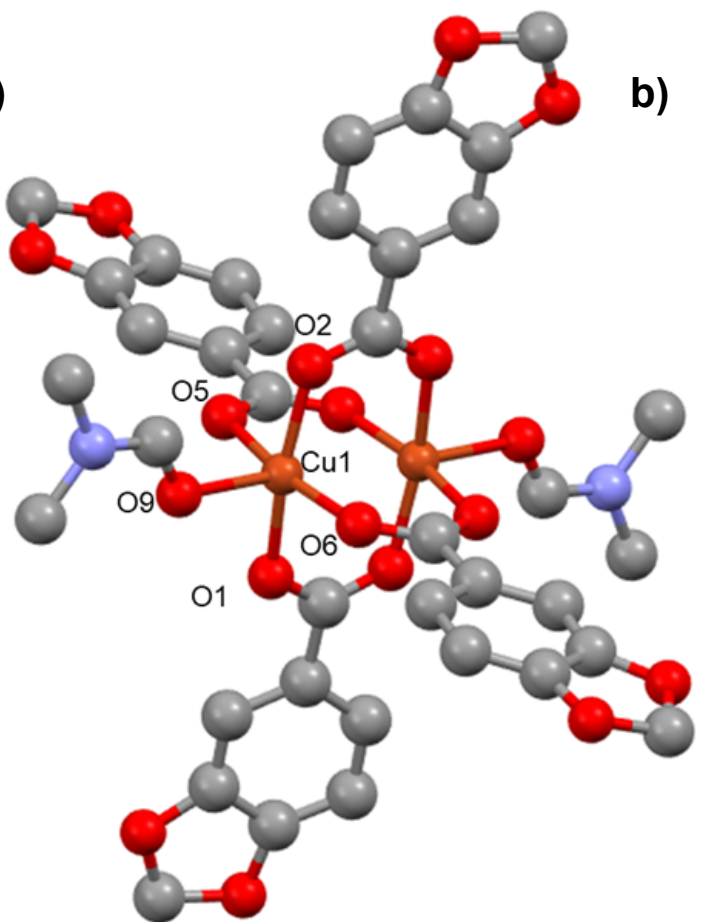

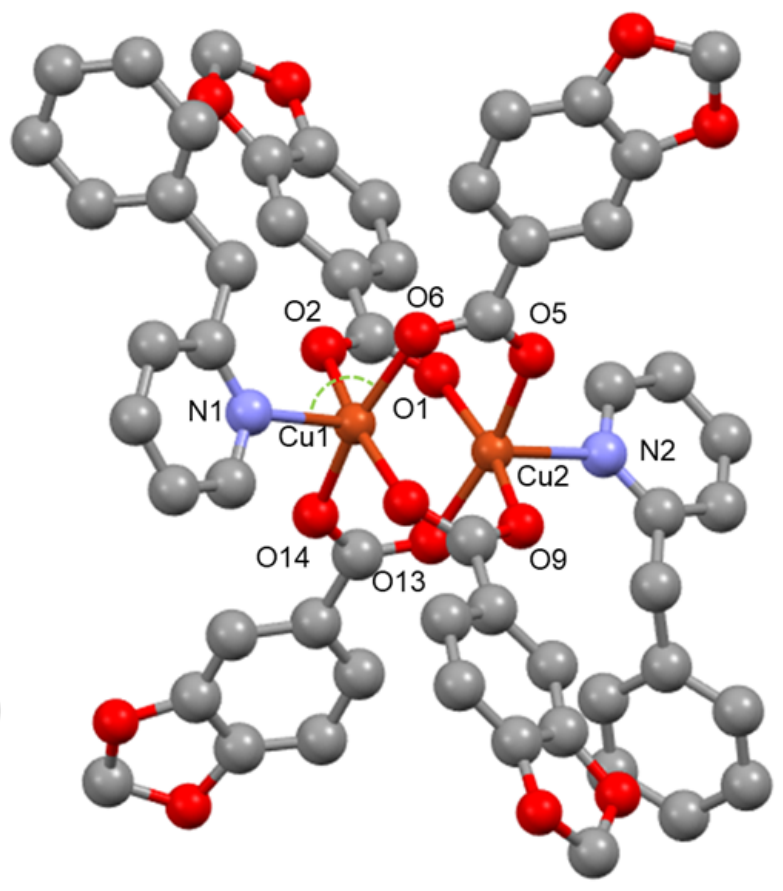

Figure 6. a. Molecular structure of $\left[\mathrm{Cu}(\mathrm{Pip})_{2}(\mathrm{DMF})\right]_{2}$ (6). b. Molecular structure of $\left[\mathrm{Cu}(\mathrm{Pip})_{2}(2-\right.$ Bzpy) $]_{2}$ (7) complexes showing an atom labelling scheme. The hydrogen atoms are omitted for clarity. 


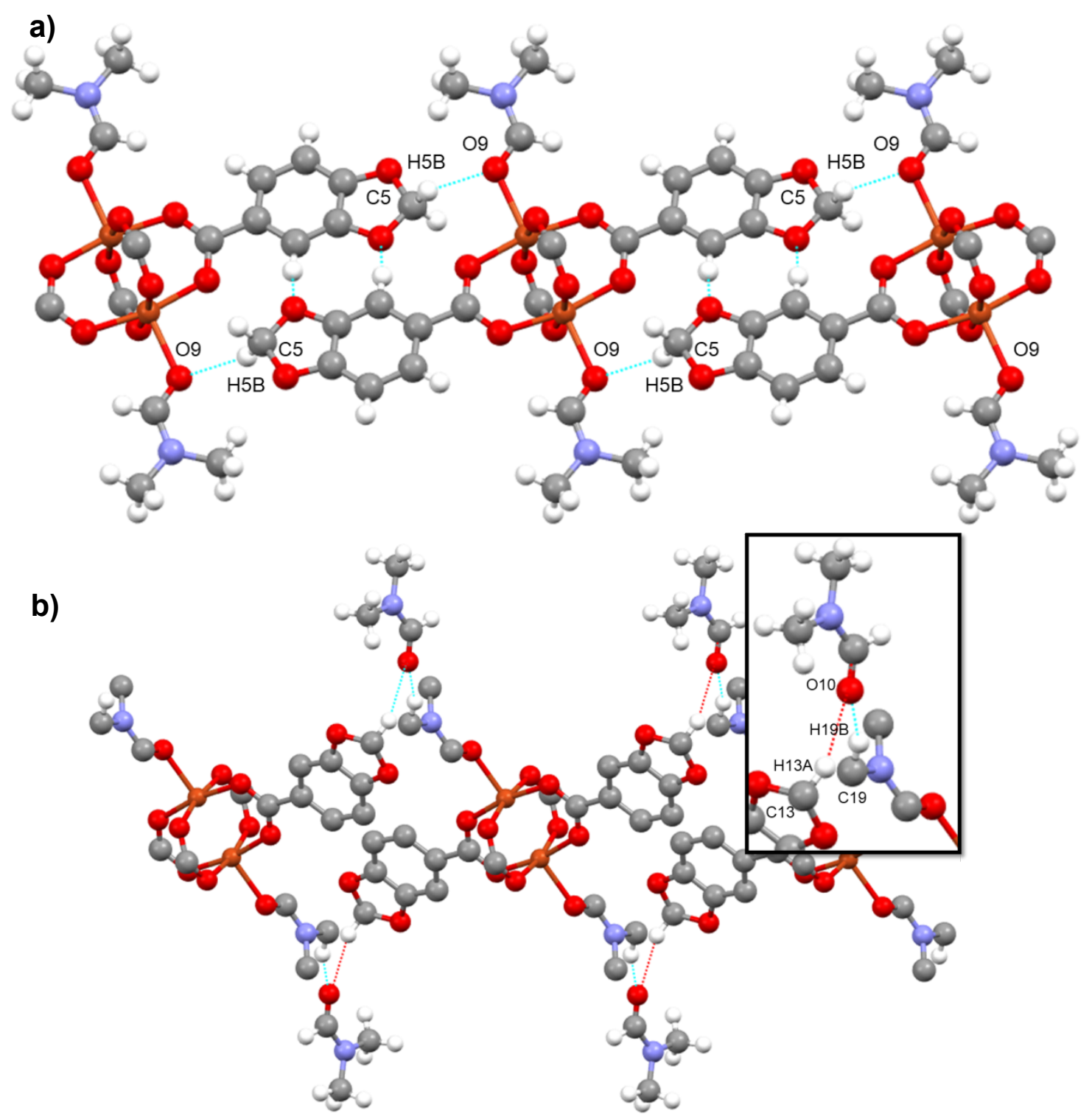

Figure 7. $a . b$ axis view of the one-dimensional ordering through the coordinated DMF molecules and the Pip rings of the $\left[\mathrm{Cu}(\mathrm{Pip})_{2}(\mathrm{DMF})\right]_{2}(\mathbf{6})$. b. ab view of the one-dimensional ordering through the uncoordinated DMF molecules joining two dimeric units of $\left[\mathrm{Cu}(\mathrm{Pip})_{2}(\mathrm{DMF})\right]_{2} \cdot 2 \mathrm{DMF}$. Only hydrogen atoms from DMF molecules and those involved in the intermolecular interaction are shown. 

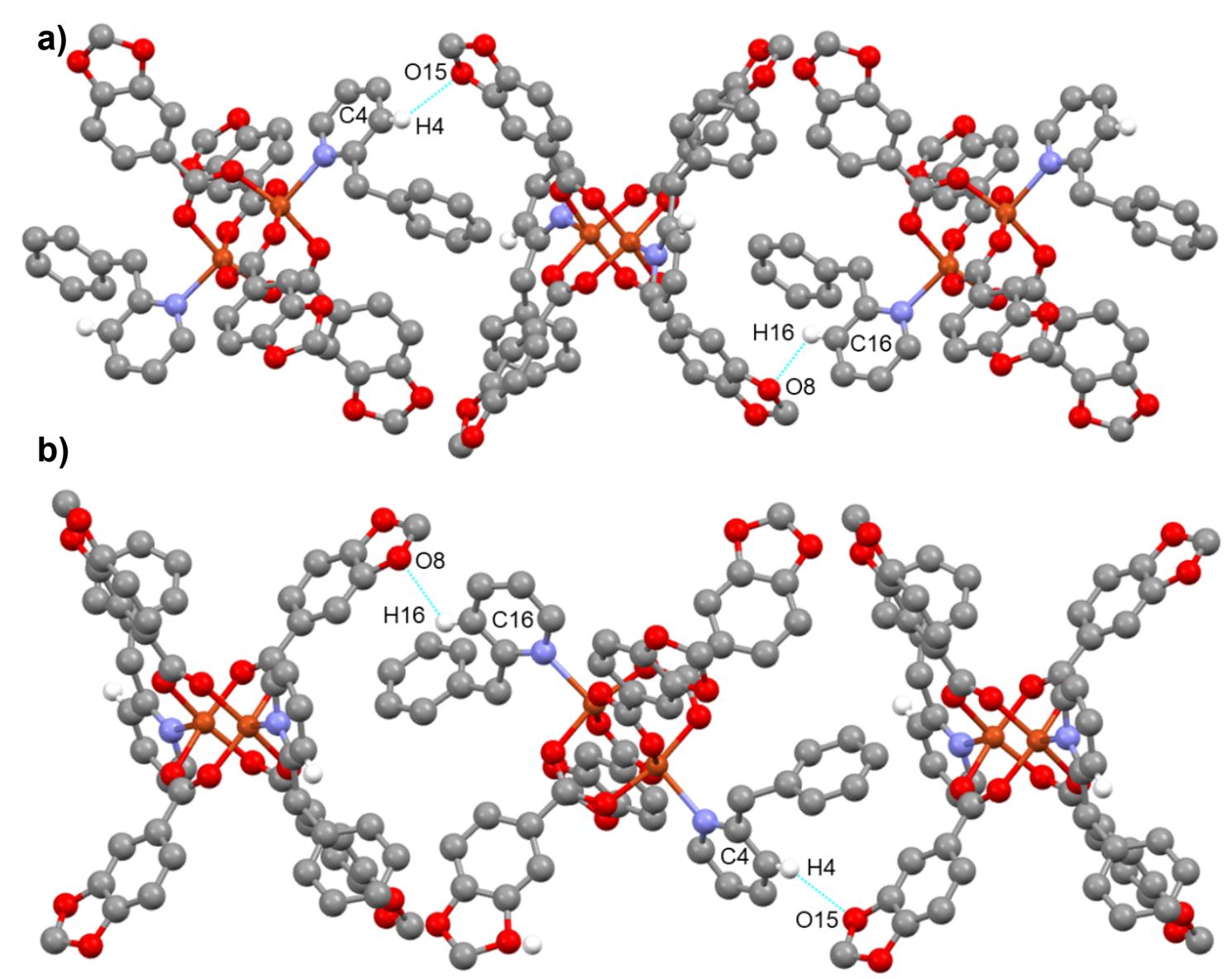

Figure 8. $\mathbf{a}$ and $\mathbf{b}$ shows the $\mathrm{C}-\mathrm{H} \cdots \mathrm{O}$ hydrogen bonding formation of compound $\mathbf{7}$ between the Pip rings and the pyridil ring of the 2-Bzpy units forming the 2D layers. a. $(1 / 31 / 21)$ view and b. $(1 / 311 / 2)$ view of these weak interactions. 


\section{Captions of Figures}

Figure 1. Molecular structure of $\left[\mathrm{Cu}(\mathrm{Pip})_{2}(\mathrm{dPy})_{2}\left(\mathrm{H}_{2} \mathrm{O}\right)\right]$ (a dPy=py (2); b 3-Phpy (3); c 4-Acpy (4)) complexes showing an atom labelling scheme. The hydrogen atoms are omitted for clarity.

Figure 2. a. $a$ axis view of the one-dimensional ordering of the $\left[\mathrm{Cu}(\mathrm{Pip})_{2}(\mathrm{py})_{2}\left(\mathrm{H}_{2} \mathrm{O}\right)\right](2)$ complex by water-carboxylate hydrogen bonding through the $b$ axis. b. Piperonylate ligands stacked in $a$ row disposition allows its intermolecular $\mathrm{C}-\mathrm{H} \cdots \mathrm{O}$ hydrogen bonding interactions.

Figure 3. a. $a$ axis view of the one-dimensional ordering of the $\left[\mathrm{Cu}(\mathrm{Pip})_{2}(3-\mathrm{Phpy})_{2}\left(\mathrm{H}_{2} \mathrm{O}\right)\right](3)$ complex by water-carboxylate hydrogen bonding through the $b$ axis. b. Piperonylates planarity drifting disposition prevent its intermolecular $\mathrm{C}-\mathrm{H} \cdots \mathrm{O}$ hydrogen bonding. Only hydrogens involved in the intermolecular interaction are shown.

Figure 4. a. $a$ axis view of the one-dimensional ordering of the $\left[\mathrm{Cu}(\mathrm{Pip})_{2}(4-\right.$ Acpy) $\left.{ }_{2}\left(\mathrm{H}_{2} \mathrm{O}\right)\right] \cdot 3 \mathrm{MeOH} \cdot \mathrm{H}_{2} \mathrm{O}(4 \mathrm{a})$ complex by water-carboxylate hydrogen bonding through the $b$ axis. $\mathbf{b}$. $b$ axis view of the propagation through the $b c$ plane by hydrogen bonding between the oxygen of the piperonylate units and the protons of the acetyl groups. Solvent molecules are omitted for clarity.

Figure 5. a. Molecular structure of $\left[\mathrm{Cu}(\mathrm{Pip})_{2}(3,5-\mathrm{dmpz})_{2}\right](5)$ complex showing an atom labelling scheme. The hydrogen atoms are omitted for clarity. $\mathbf{b}$. $\mathbf{b}$ axis view of the one-dimensional ordering of the $\left[\mathrm{Cu}(\mathrm{Pip})_{2}(3,5-\mathrm{dmpz})_{2}\right]$ (5) complex by a double pirazole-carboxylate hydrogen bonding forming $1 \mathrm{D}$ chains. Only hydrogen atoms involved in the intermolecular interactions are shown.

Figure 6. a. Molecular structure of $\left[\mathrm{Cu}(\mathrm{Pip})_{2}(\mathrm{DMF})\right]_{2}$ (6). b. Molecular structure of $\left[\mathrm{Cu}(\mathrm{Pip})_{2}(2-\right.$ Bzpy) $]_{2}$ (7) complexes showing an atom labelling scheme. The hydrogen atoms are omitted for clarity.

Figure 7. a. $b$ axis view of the one-dimensional ordering through the coordinated DMF molecules and the Pip rings of the $\left[\mathrm{Cu}(\mathrm{Pip})_{2}(\mathrm{DMF})\right]_{2}(\mathbf{6})$. $\mathbf{b} . a b$ view of the one-dimensional ordering through the uncoordinated DMF molecules joining two dimeric units of $\left[\mathrm{Cu}(\mathrm{Pip})_{2}(\mathrm{DMF})\right]_{2} \cdot 2 \mathrm{DMF}$. Only hydrogen atoms from DMF molecules and those involved in the intermolecular interaction are shown.

Figure 8. $\mathbf{a}$ and $\mathbf{b}$ shows the $\mathrm{C}-\mathrm{H} \cdots \mathrm{O}$ hydrogen bonding formation of compound $\mathbf{7}$ between the Pip rings and the pyridil ring of the 2-Bzpy units forming the 2D layers. a. $(1 / 31 / 21)$ view and b. $(1 / 311 / 2)$ view of these weak interactions. 


\section{Supporting Information}

\section{Reactivity of homoleptic and heteroleptic core paddle wheel $\mathrm{Cu}$ (II) compounds}

Francisco Sánchez-Férez ${ }^{a}$, Miguel Guerrero ${ }^{a}$, José A. Ayllón ${ }^{a}$, Teresa Calvet ${ }^{b}$, Mercè FontBardía c, José Giner Planas ${ }^{d}$, Josefina Pons ${ }^{a, *}$.

${ }^{a}$ Departament de Química, Universitat Autònoma de Barcelona, 08193-Bellaterra, Barcelona, Spain

${ }^{b}$ Cristal·lografia, Mineralogia I Dipòsits Minerals, Universitat de Barcelona, Martí i Franquès s/n, 08028 Barcelona, Spain

${ }^{c}$ Unitat de Difracció de Raig-X, Centres Científics i Tecnològics de la Universitat de Barcelona (CCiYUB), Universitat de Barcelona, Solé I Sabarís, 1-3, 08028 Barcelona, Spain

${ }^{d}$ Institut de Ciència de Materials de Barcelona (ICMAB-CSIC), Campus UAB, 08193 Bellaterra, Spain. 


\section{Powder X-Ray Diffraction Patterns}

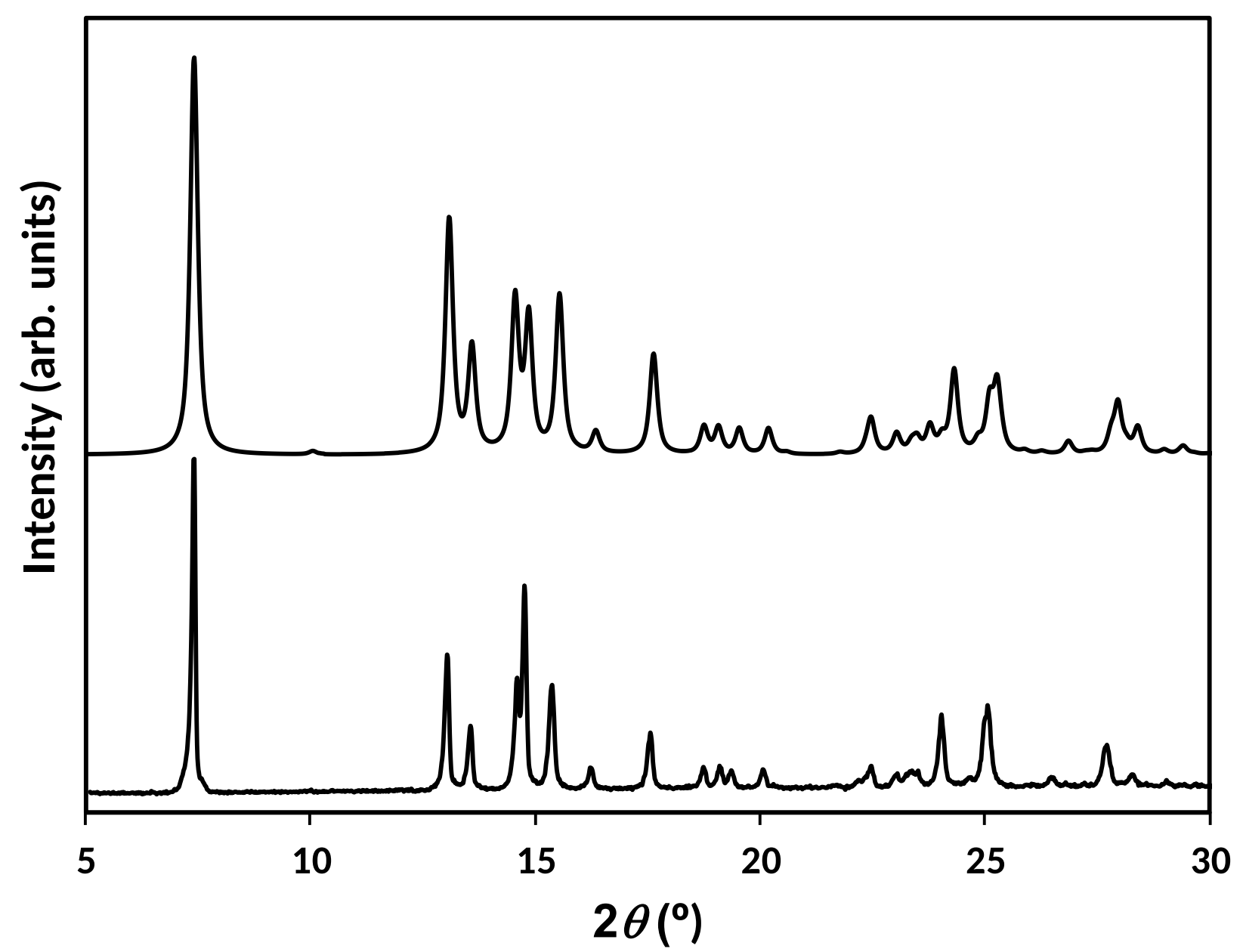

Figure S1. PXRD of $[\mathrm{Cu}(\mu-\mathrm{Pip})(\mu-\mathrm{Ac})(\mathrm{MeOH})]_{2}$ (1). Simulated (top) and experimental (bottom). 


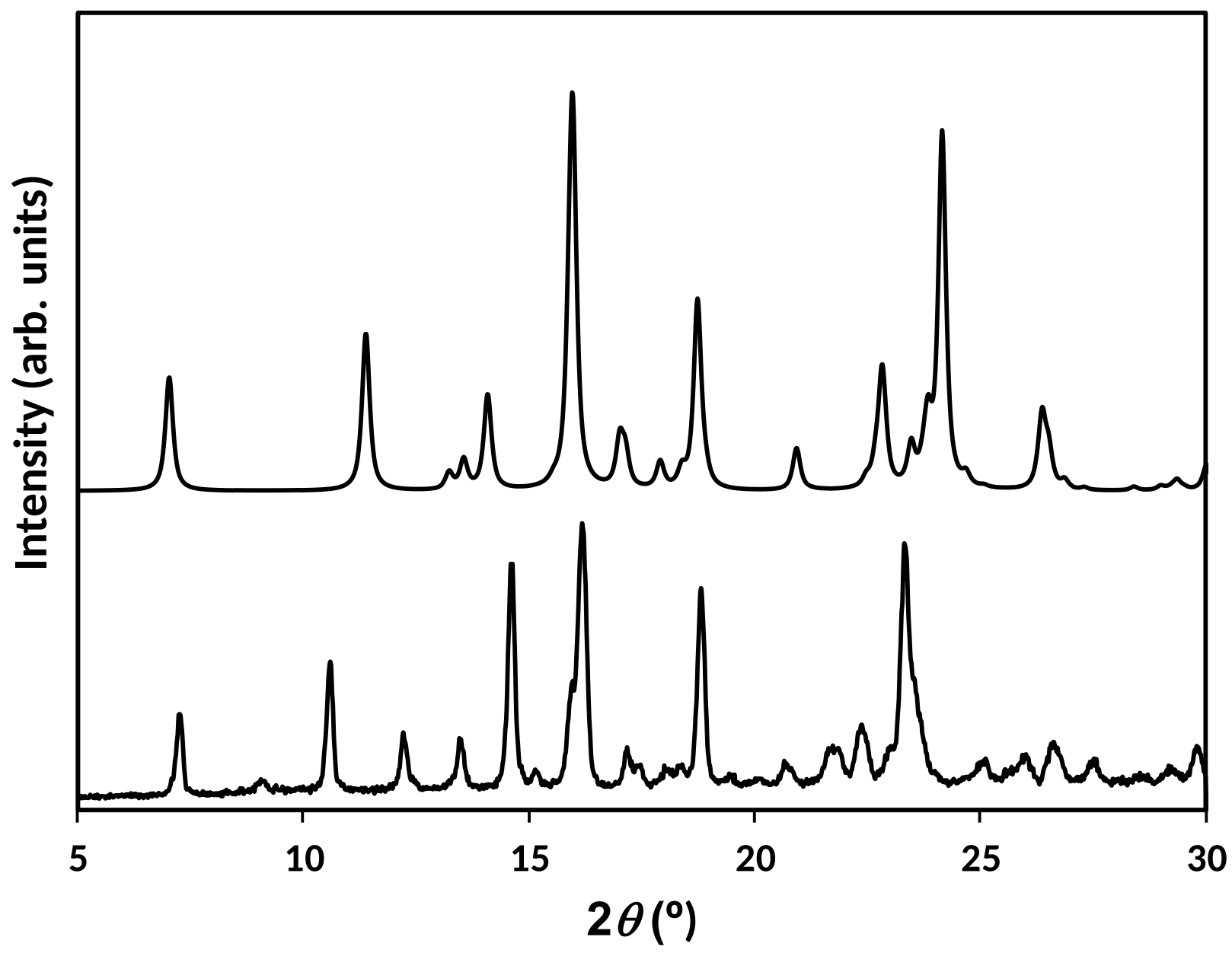

Figure S2. PXRD of $\left[\mathrm{Cu}(\mathrm{Pip})_{2}(\mathrm{py})_{2}\left(\mathrm{H}_{2} \mathrm{O}\right)\right]$ (2). Simulated (top) and experimental (bottom). 


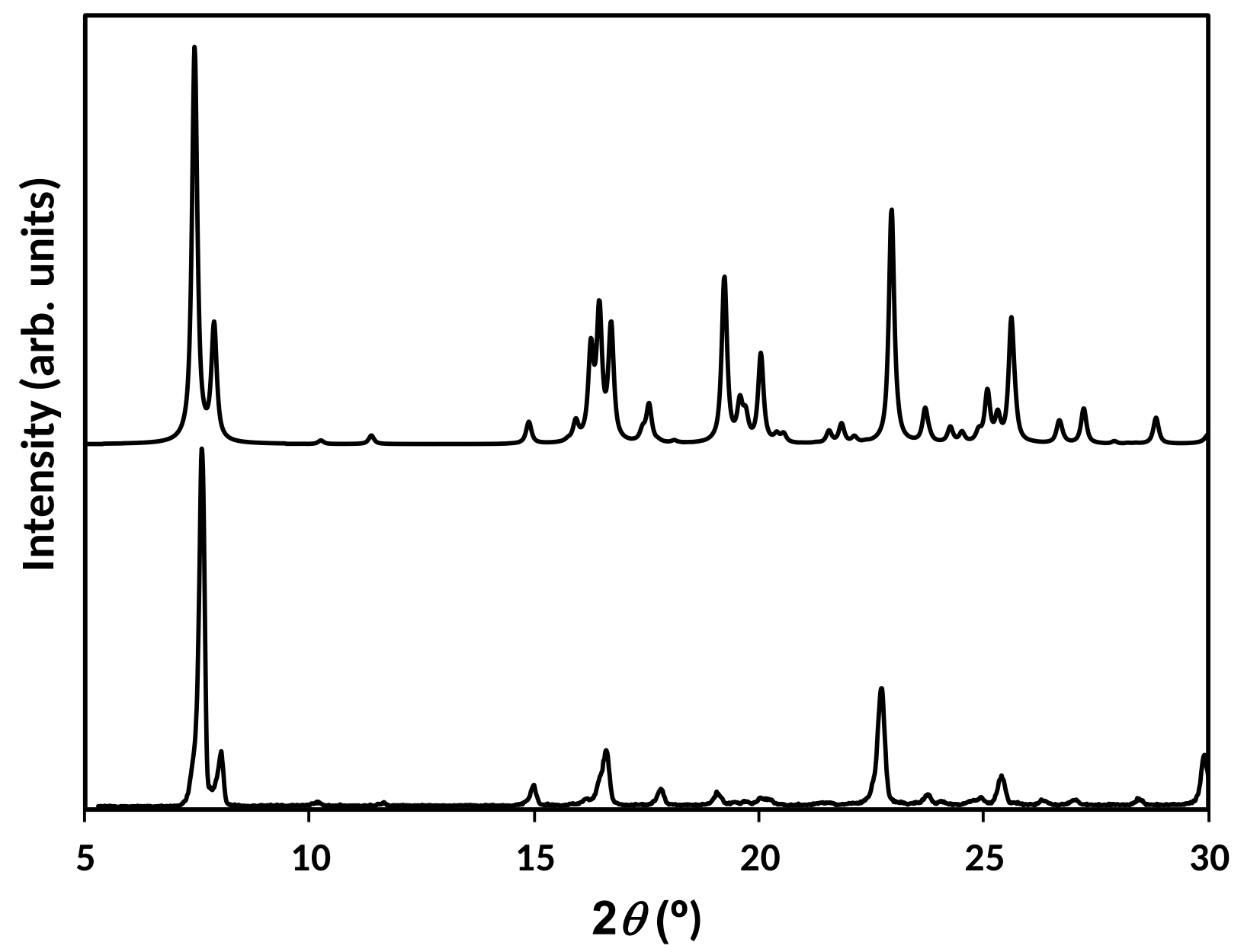

Figure S3. PXRD of $\left[\mathrm{Cu}(\mathrm{Pip})_{2}(3-\mathrm{Phpy})_{2}\left(\mathrm{H}_{2} \mathrm{O}\right)\right]$ (3). Simulated (top) and experimental (bottom). 


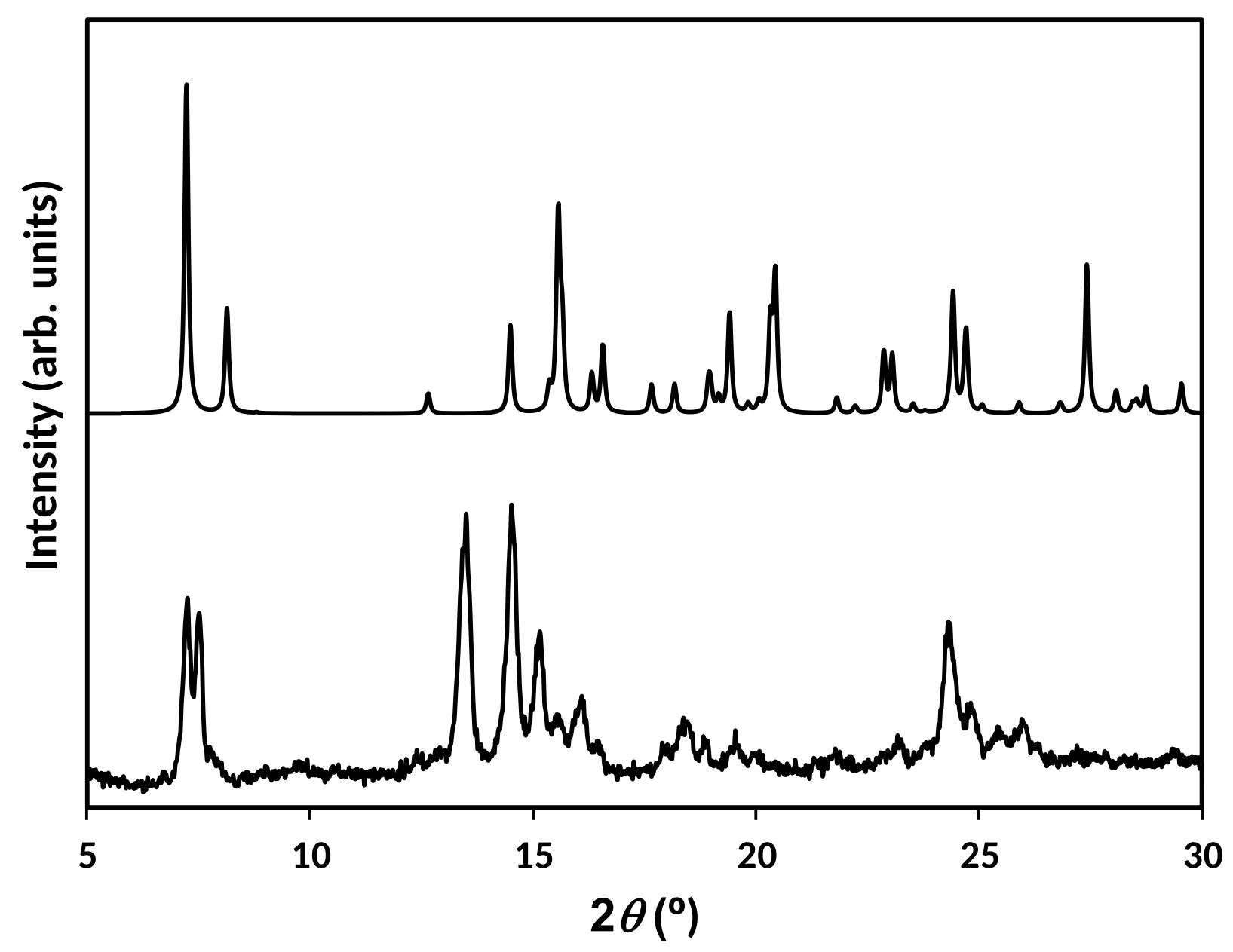

Figure S4. PXRD of $\left[\mathrm{Cu}(\mathrm{Pip})_{2}(4-\mathrm{Acpy})_{2}\left(\mathrm{H}_{2} \mathrm{O}\right)\right] \cdot 3 \mathrm{MeOH} \cdot \mathrm{H}_{2} \mathrm{O}$ (4a), simulated (top). PXRD of $\left[\mathrm{Cu}(\mathrm{Pip})_{2}(4-\mathrm{Acpy})_{2}\left(\mathrm{H}_{2} \mathrm{O}\right)\right](4 \mathbf{b})$, experimental (bottom). 


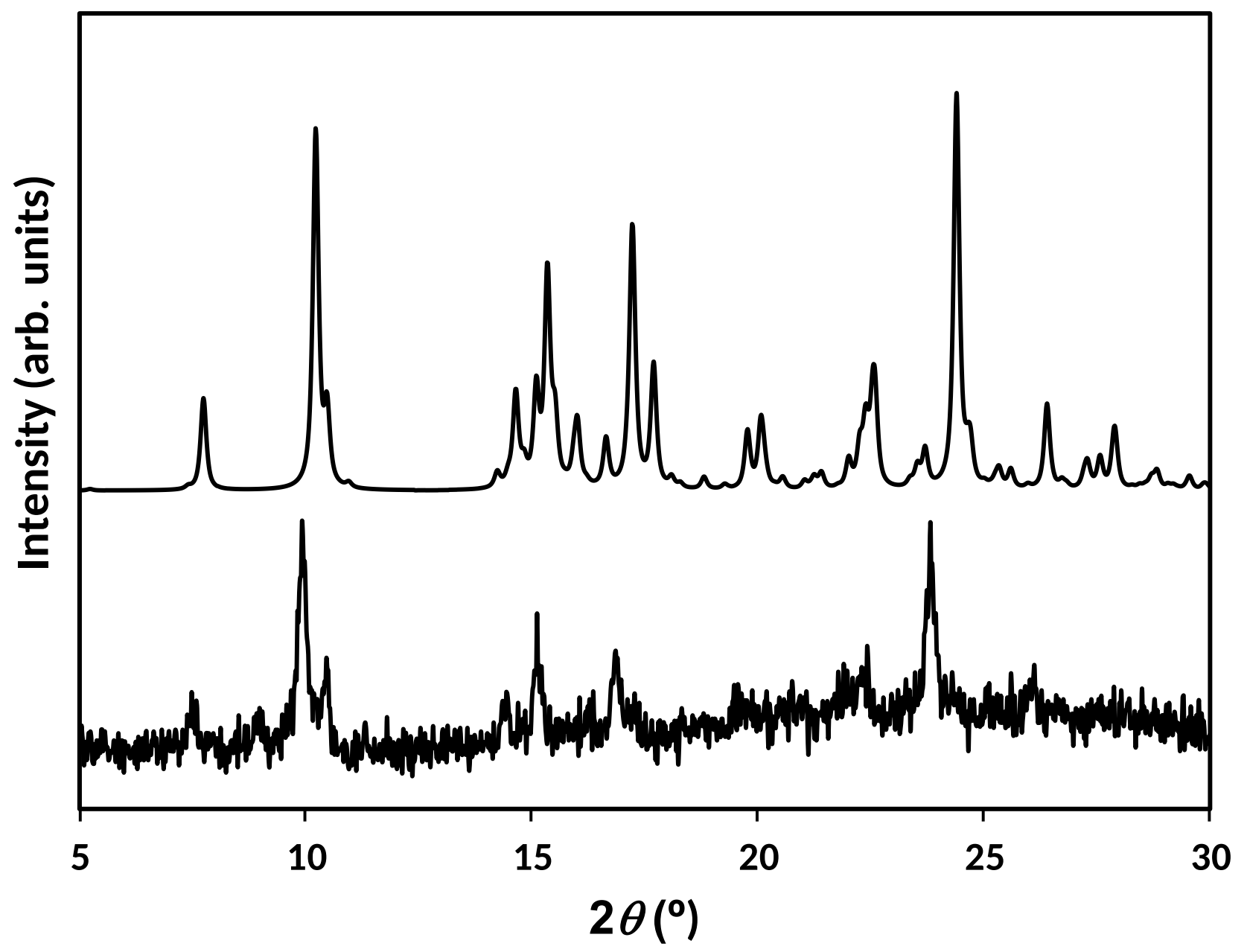

Figure S5. PXRD of [Cu(Pip) $\left.)_{2}(3,5-\mathrm{dmpz})_{2}\right]$ (5). Simulated (top) and experimental (bottom). 


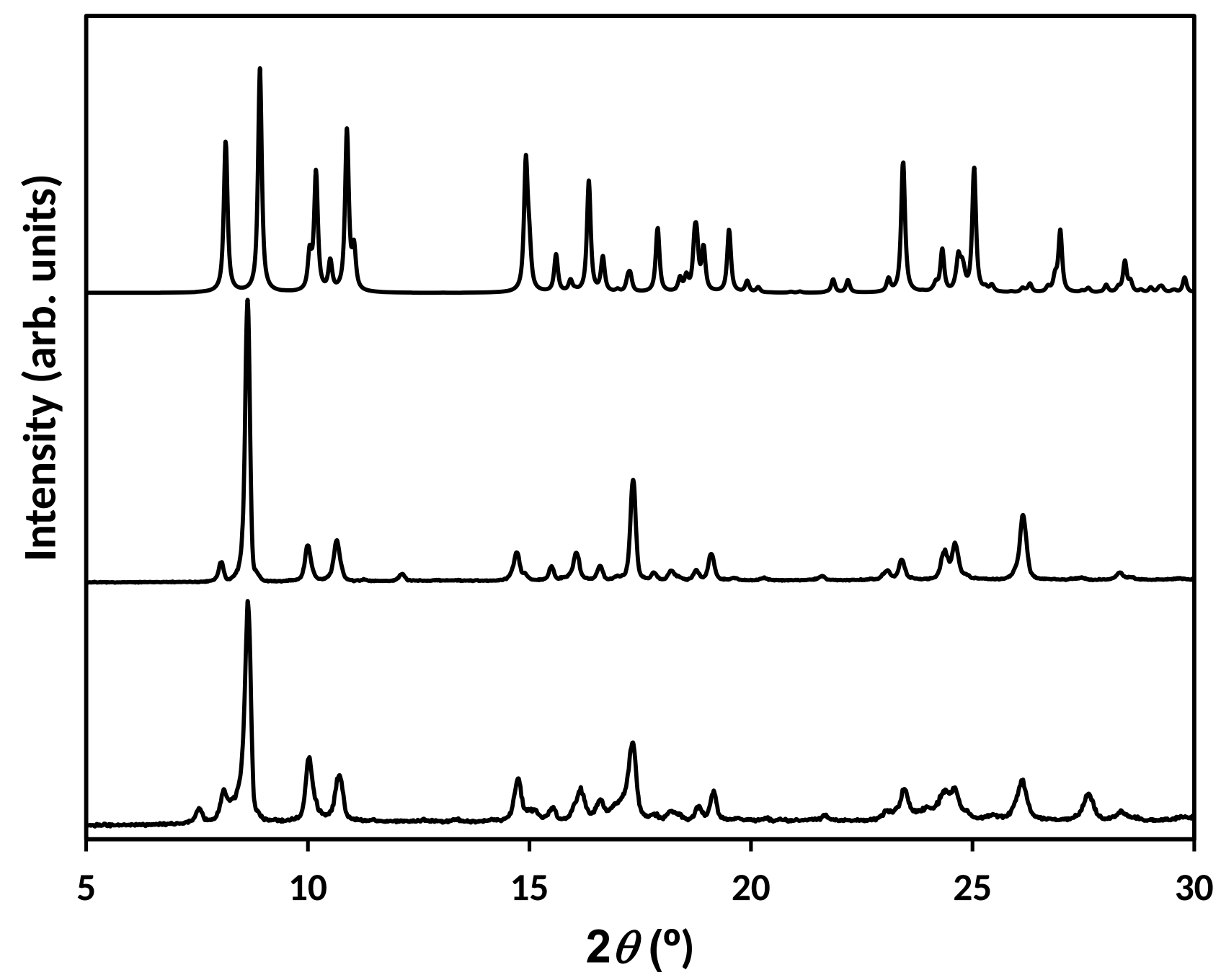

Figure S6. PXRD of $\left[\mathrm{Cu}(\mathrm{Pip})_{2}(\mathrm{DMF})_{2}\right]_{2} \cdot 2 \mathrm{DMF}(\mathbf{6})$. Simulated (top) and experimental starting from copper acetate (method B, middle) or from $\mathbf{1}$ (method A, bottom). 


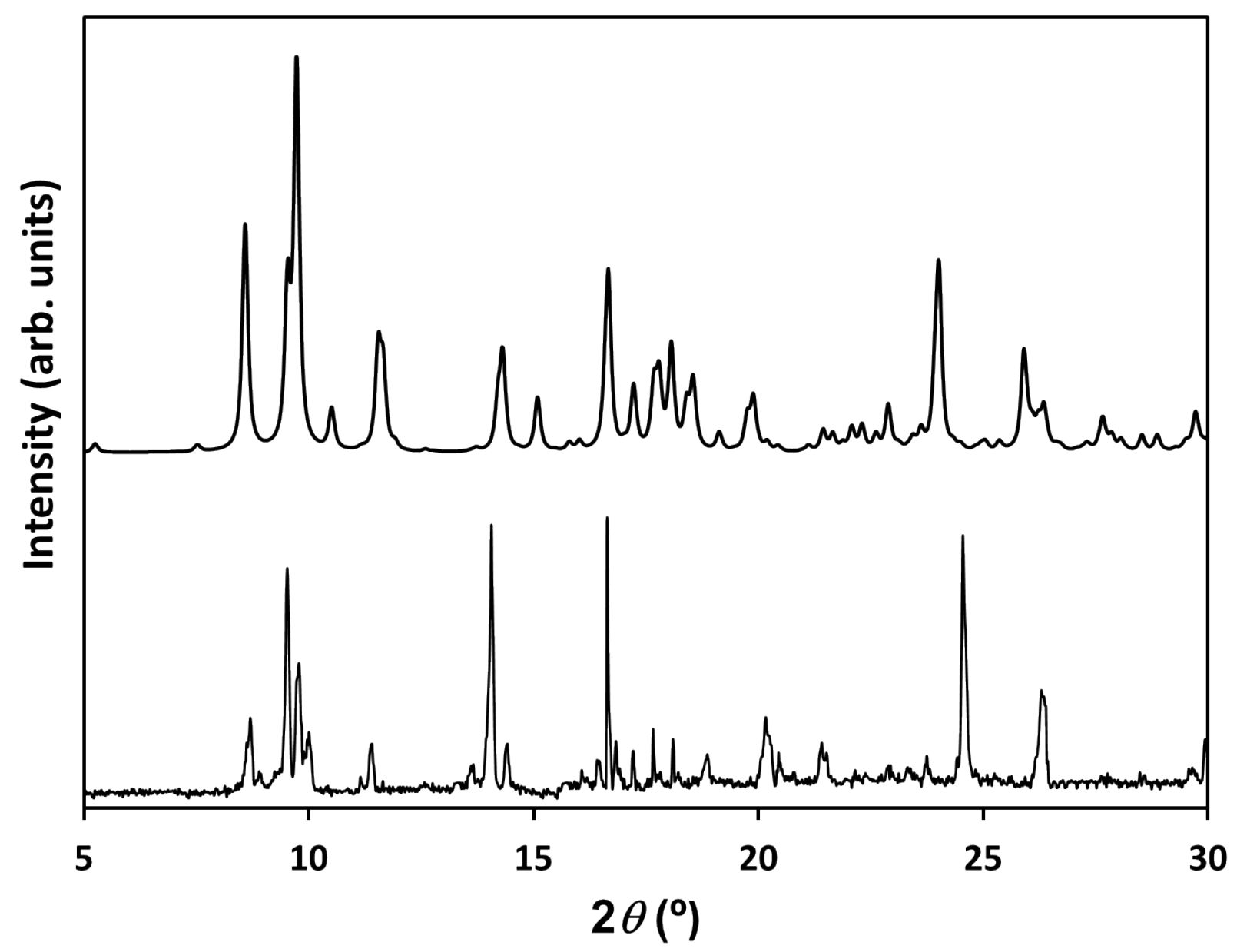

Figure S7. PXRD of $\left[\mathrm{Cu}(\mathrm{Pip})_{2}(2-\mathrm{Bzpy})\right]_{2}$ (7). Simulated (top) and experimental (bottom). 


\section{Infrared spectroscopy}

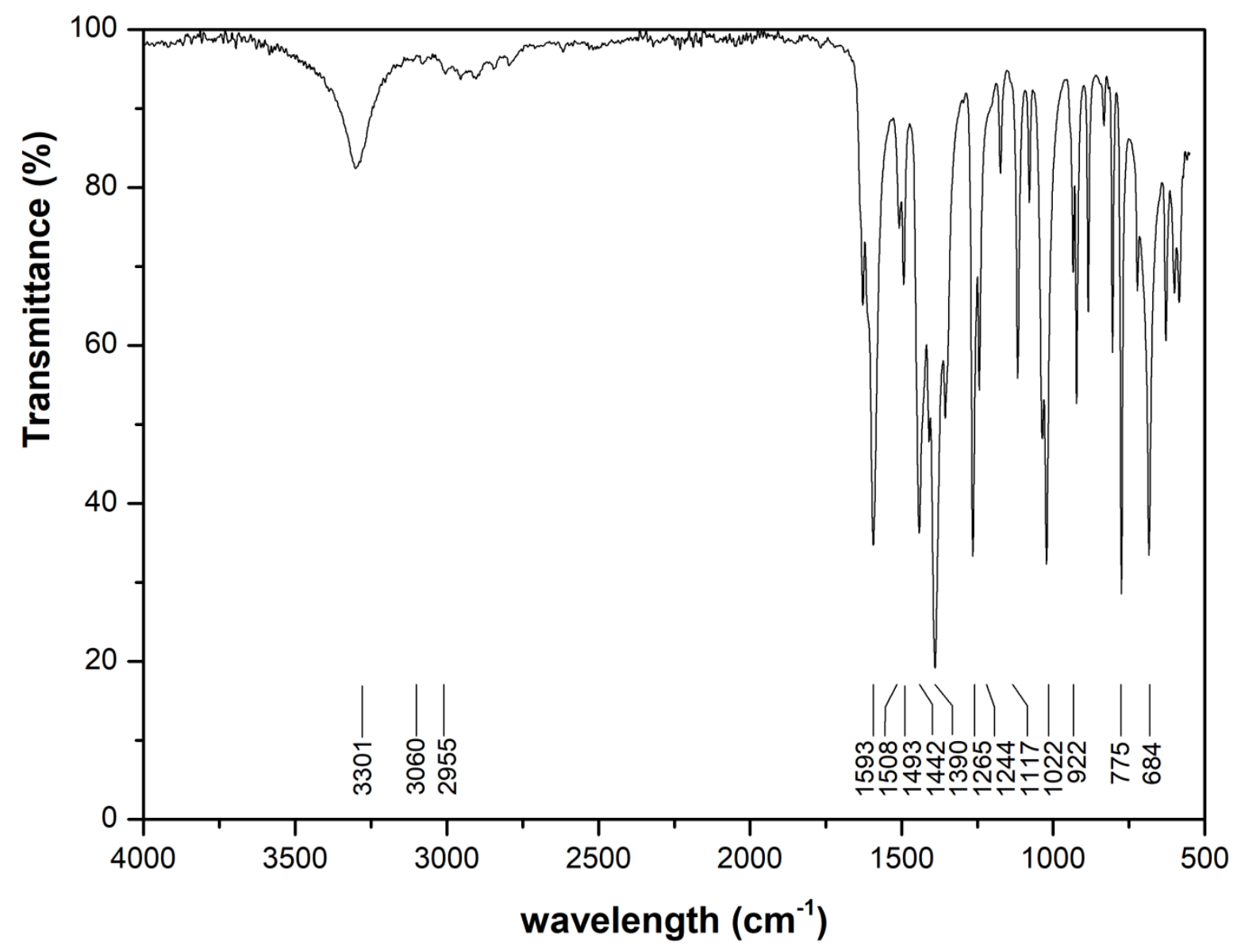

Figure S8. ATR-FTIR spectrum of $[\mathrm{Cu}(\mu-\mathrm{Pip})(\mu-\mathrm{OAc})(\mathrm{MeOH})]_{2}(\mathbf{1})$. 


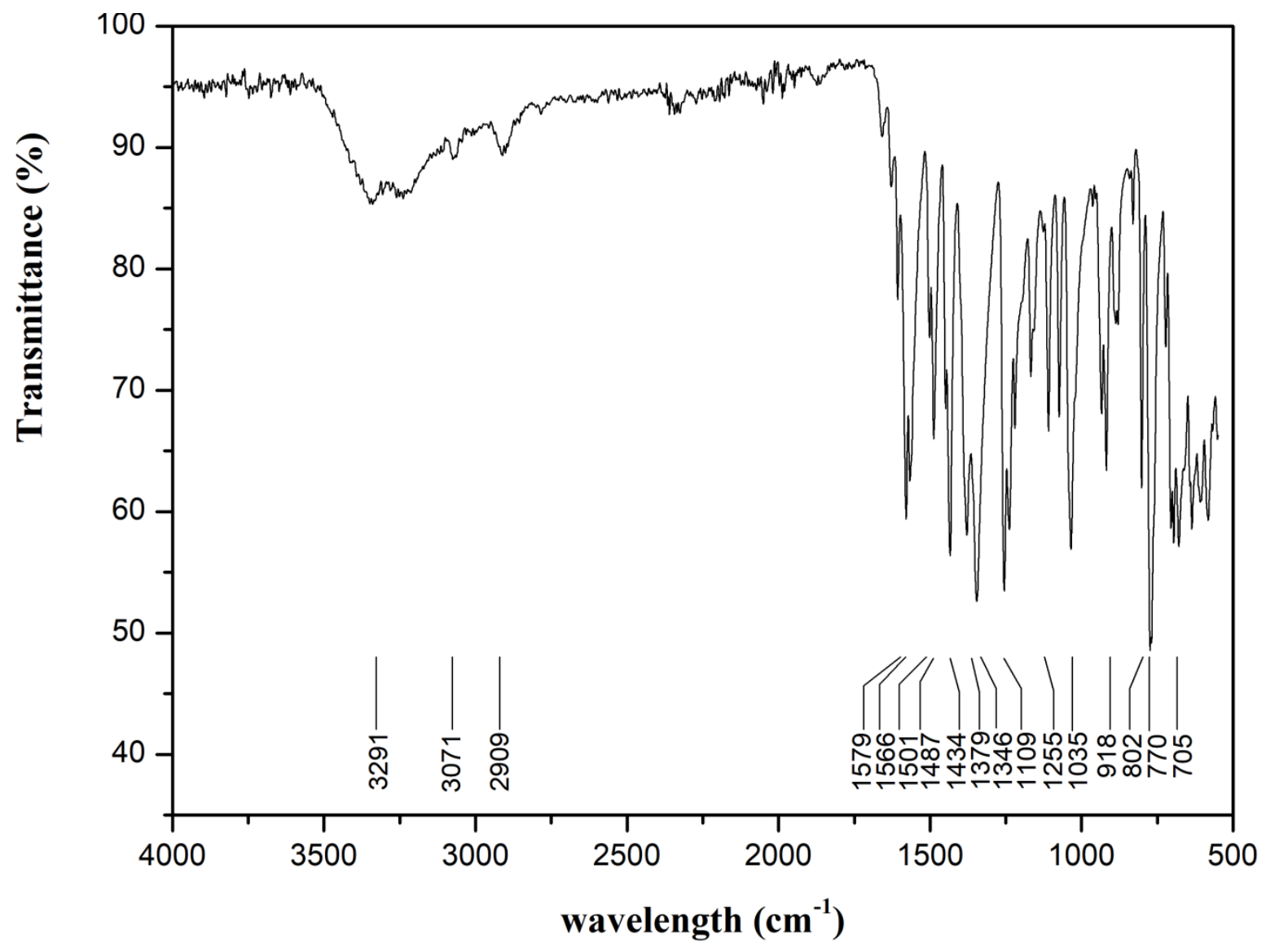

Figure S9. ATR-FTIR spectrum of $\left[\mathrm{Cu}(\mathrm{Pip})_{2}(\mathrm{py})_{2}\left(\mathrm{H}_{2} \mathrm{O}\right)\right](2)$. 


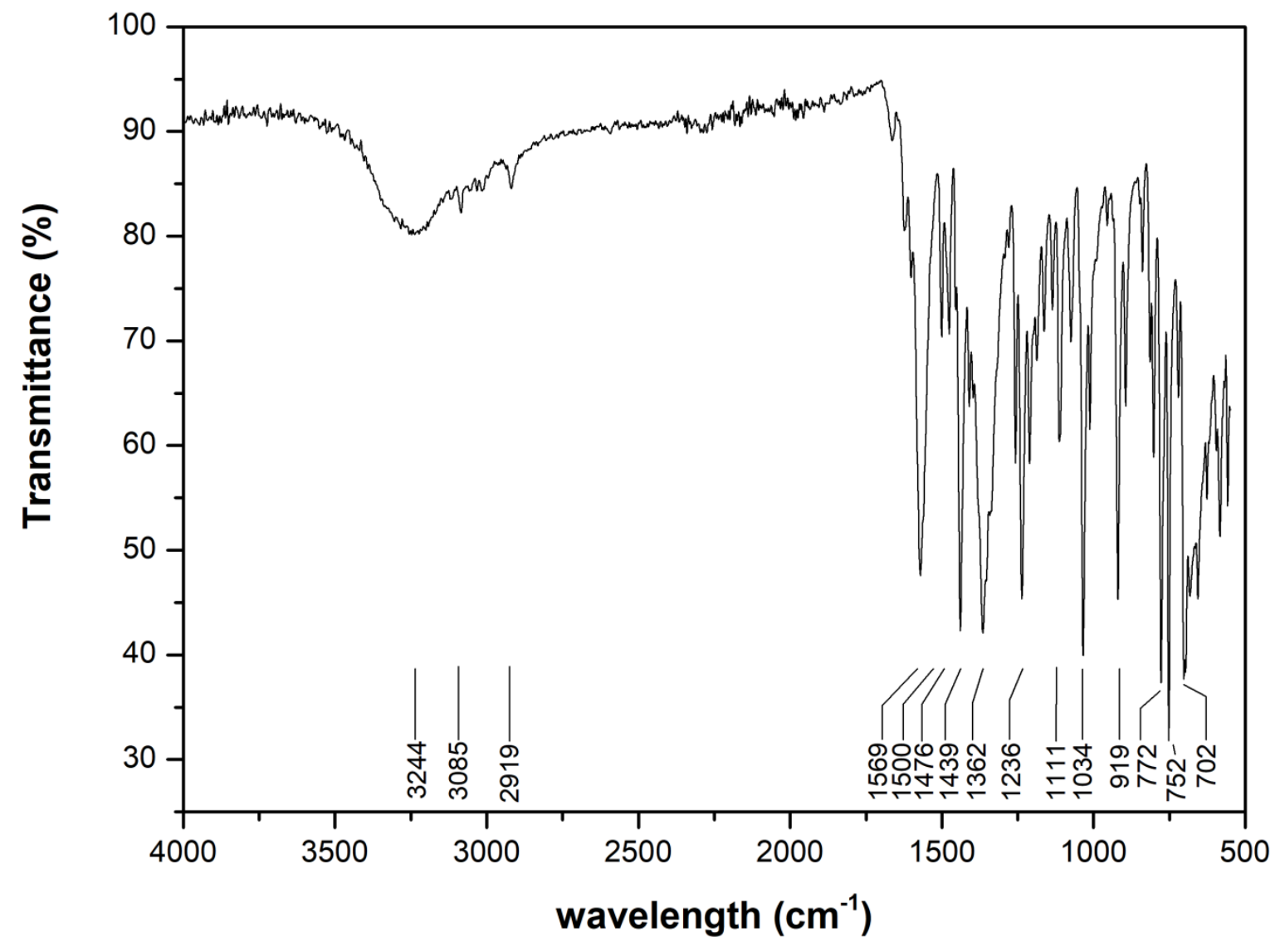

Figure S10. ATR-FTIR spectrum of $\left[\mathrm{Cu}(\mathrm{Pip})_{2}(3-\mathrm{Phpy})_{2}\left(\mathrm{H}_{2} \mathrm{O}\right)\right](3)$. 
a)

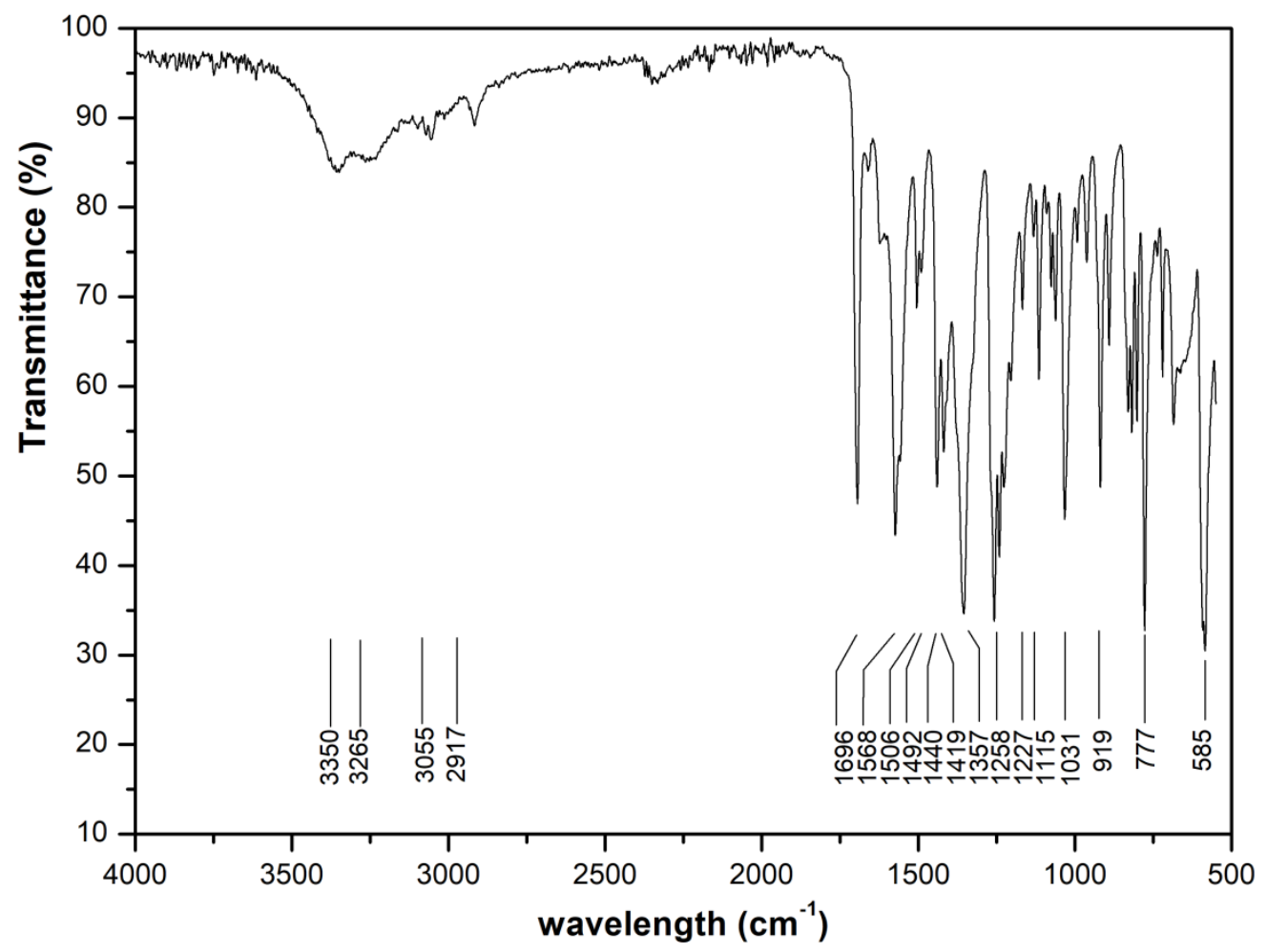

b)

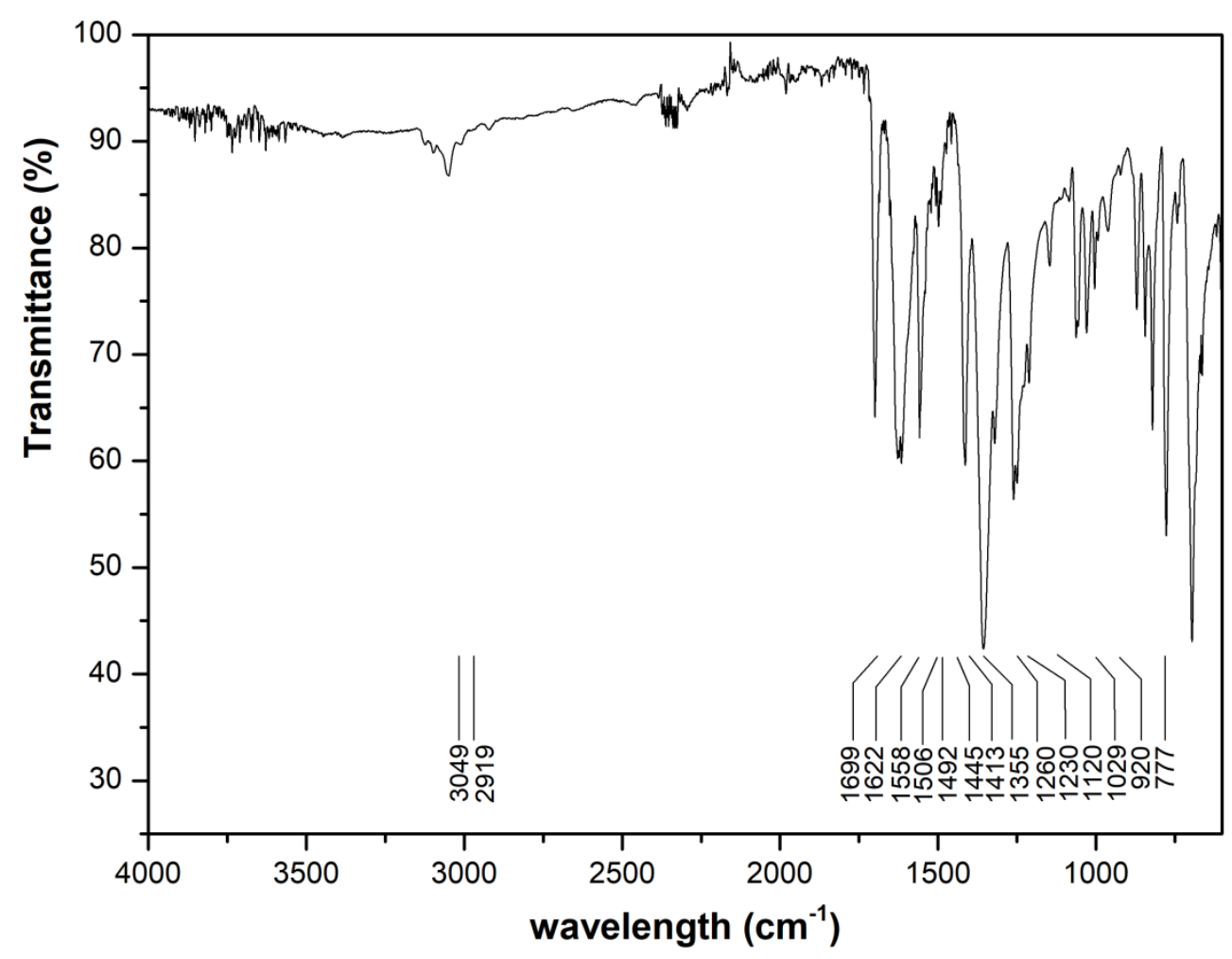

Figure S11. a. ATR-FTIR spectrum of $\left[\mathrm{Cu}(\mathrm{Pip})_{2}(4-\mathrm{Acpy})_{2}\left(\mathrm{H}_{2} \mathrm{O}\right)\right] \cdot 3 \mathrm{MeOH} \cdot \mathrm{H}_{2} \mathrm{O}(\mathbf{4 a})$. b. ATRFTIR spectrum of $\left[\mathrm{Cu}(\mathrm{Pip})_{2}(4-\mathrm{Acpy})_{2}\left(\mathrm{H}_{2} \mathrm{O}\right)\right](\mathbf{4} \mathbf{b})$, corresponding to the powder after vacuum conditions. It can be appreciated the disappearance of the $[\mathrm{v}(\mathrm{O}-\mathrm{H})]$ bands at 3350 and $3265 \mathrm{~cm}^{-1}$. 


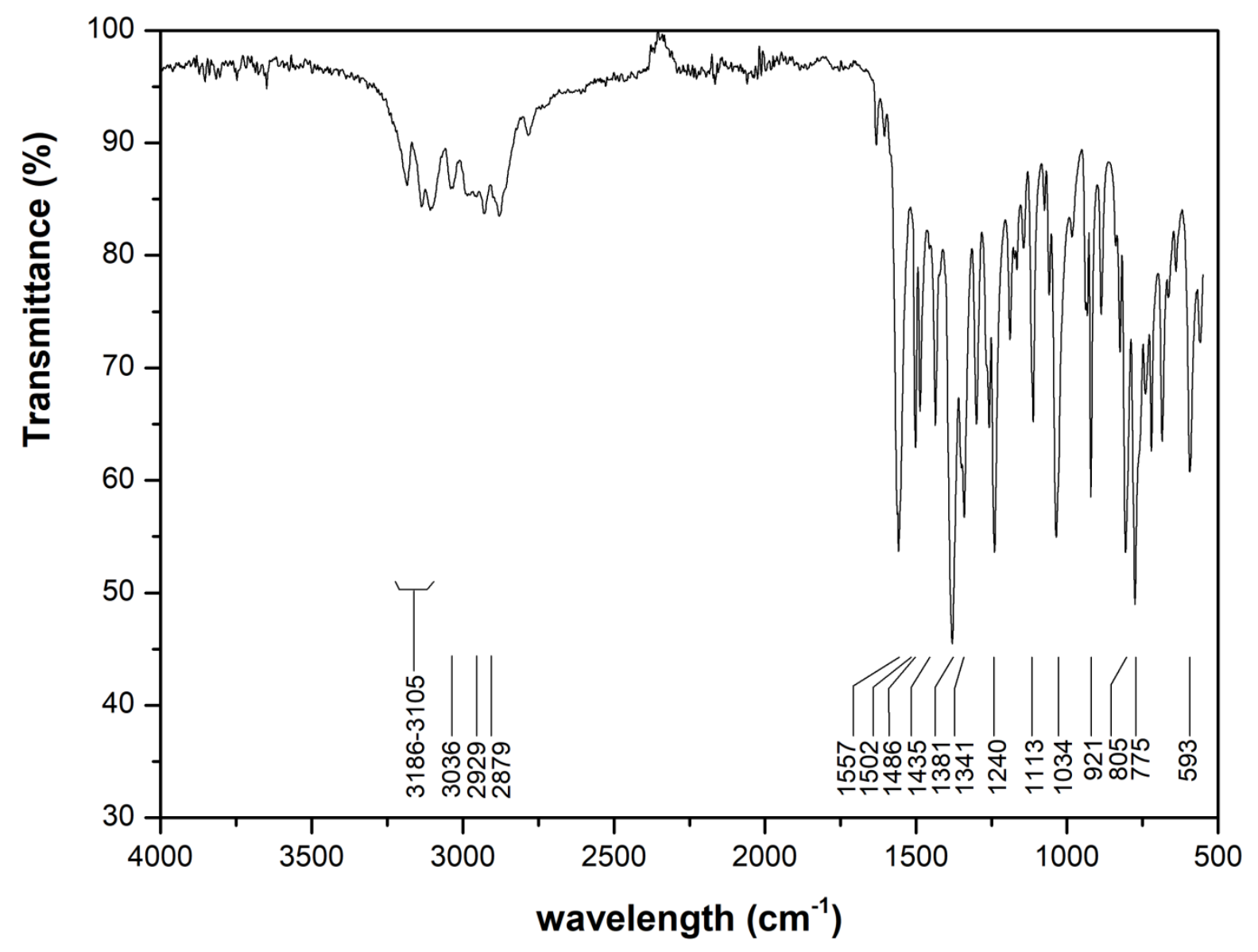

Figure S12. ATR-FTIR spectrum of $\left[\mathrm{Cu}(\mathrm{Pip})_{2}(3,5-\mathrm{dmpz})_{2}\right]$ (5). 


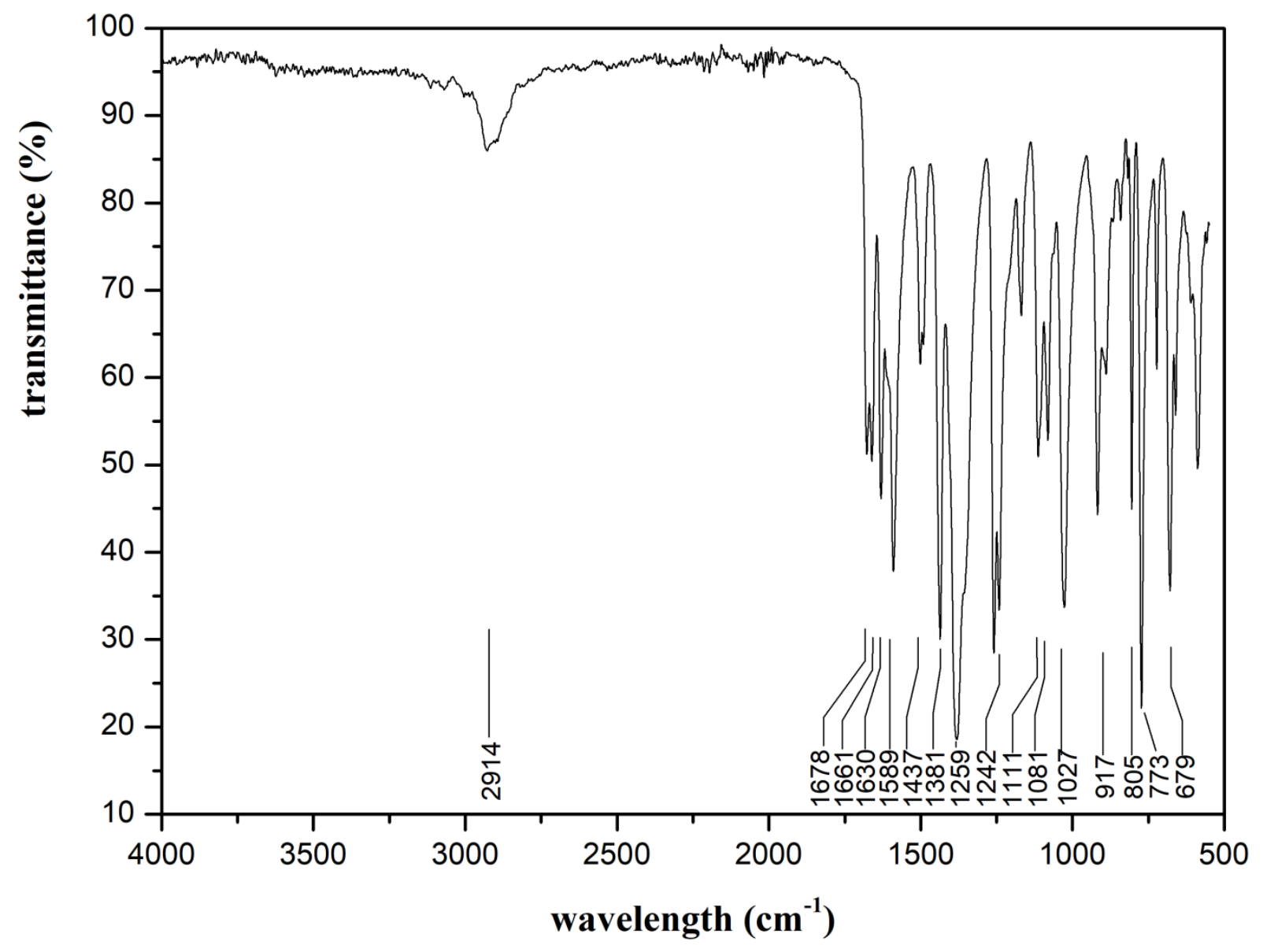

Figure S13. ATR-FTIR spectrum of $\left[\mathrm{Cu}(\mathrm{Pip})_{2}(\mathrm{DMF})_{2}\right]_{2} \cdot 2 \mathrm{DMF}(\mathbf{6})$. 


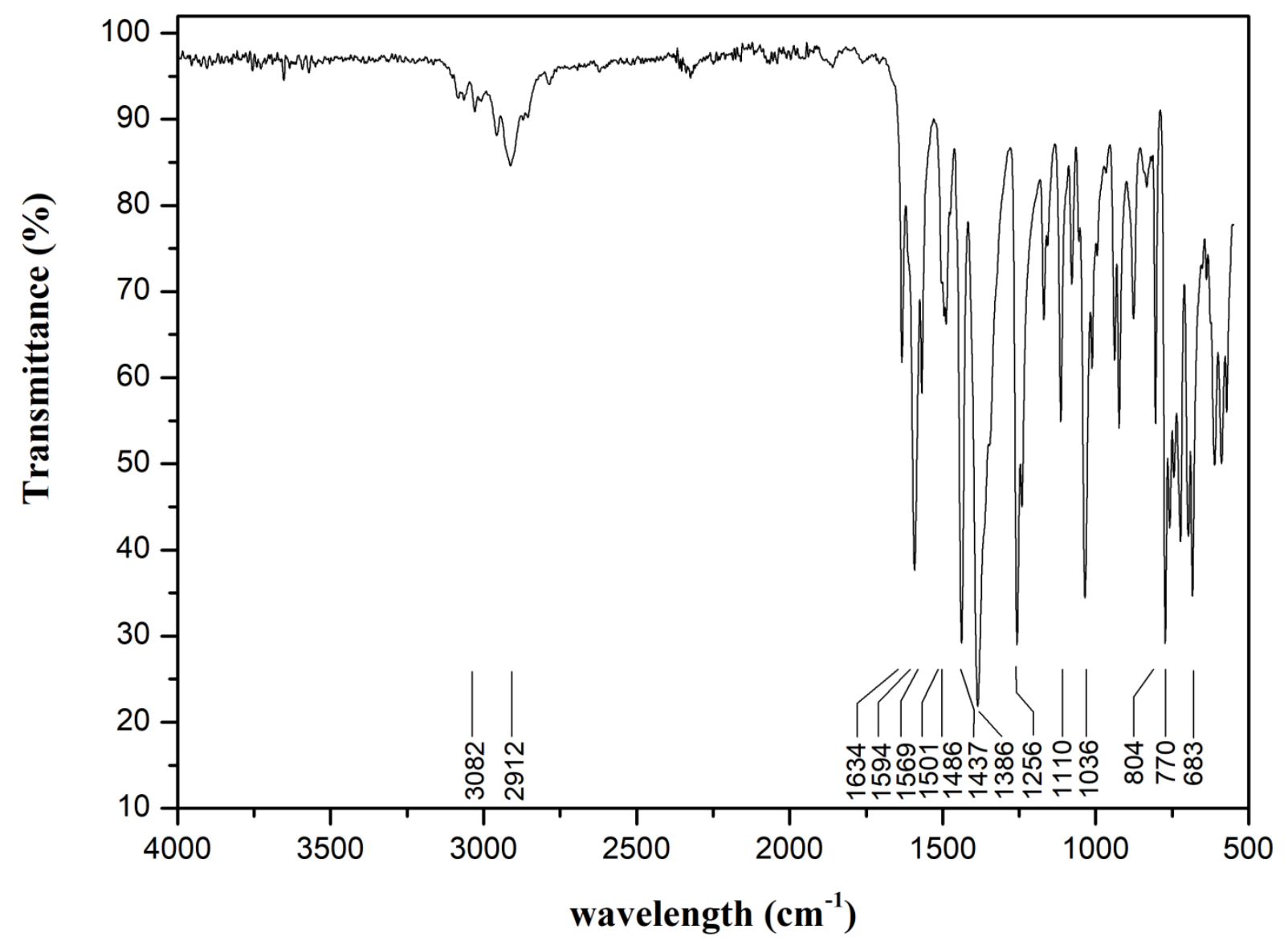

Figure S14. ATR-FTIR spectrum of $\left[\mathrm{Cu}(\mathrm{Pip})_{2}(2-\mathrm{Bzpy})\right]_{2}(7)$. 
UV-Vis spectroscopy

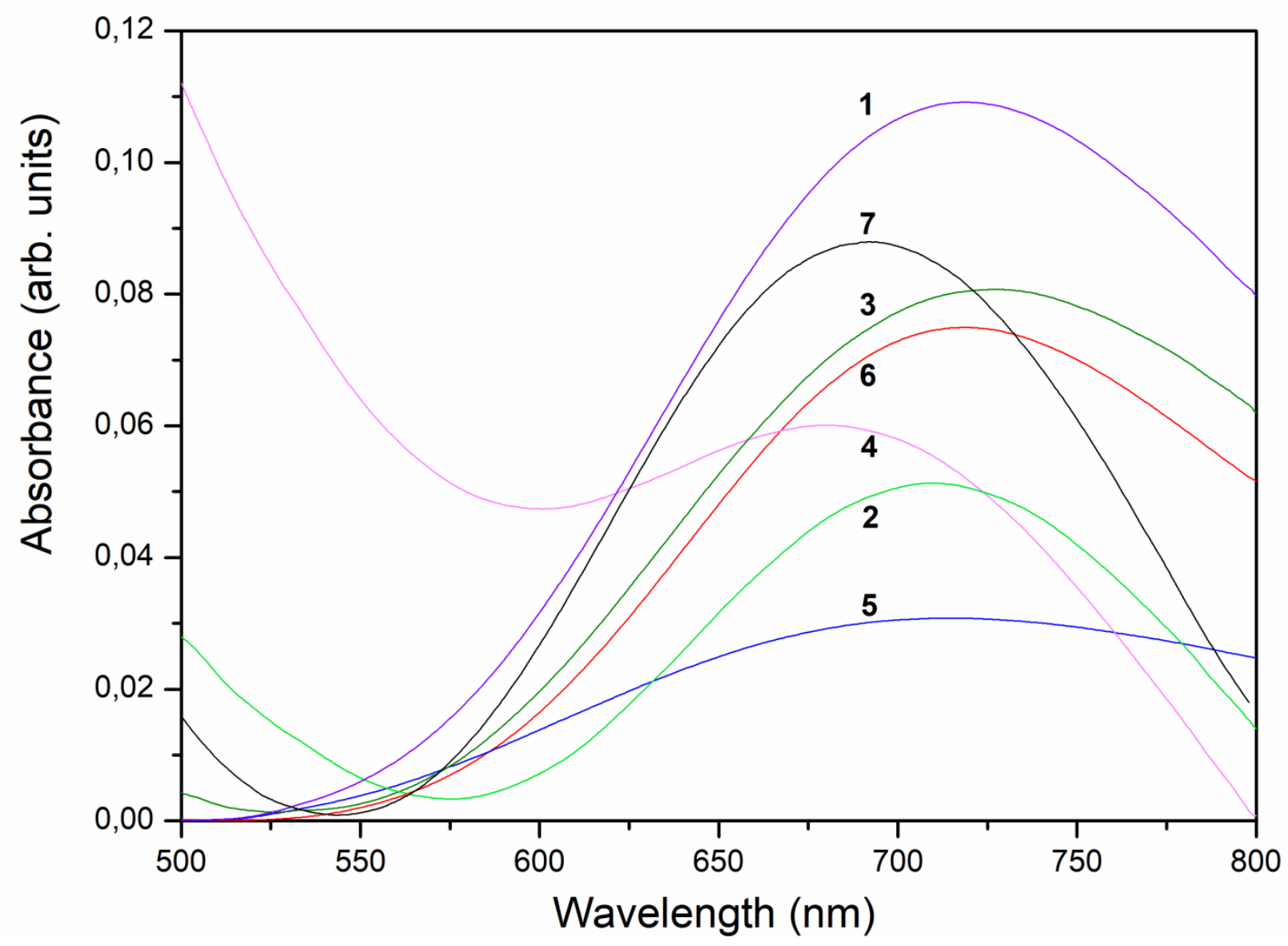

Figure S15. UV-Vis spectra of $[\mathrm{Cu}(\mu-\mathrm{Pip})(\mu-\mathrm{Ac})(\mathrm{MeOH})]_{2}(\mathbf{1}),\left[\mathrm{Cu}(\mathrm{Pip})_{2}(\mathrm{py})_{2}\left(\mathrm{H}_{2} \mathrm{O}\right)\right]$ (2), $\left[\mathrm{Cu}(\mathrm{Pip})_{2}(3-\mathrm{Phpy})_{2}\left(\mathrm{H}_{2} \mathrm{O}\right)\right] \quad$ (3), $\quad\left[\mathrm{Cu}(\mathrm{Pip})_{2}(4-\mathrm{Acpy})_{2}\left(\mathrm{H}_{2} \mathrm{O}\right)\right] \quad$ (4), [Cu(Pip) $\left.)_{2}(3,5-\mathrm{dmpz})_{2}\right] \quad$ (5), $\left[\mathrm{Cu}(\mathrm{Pip})_{2}(\mathrm{DMF})_{2}\right]_{2} \cdot 2 \mathrm{DMF}(\mathbf{6})$ and $\left[\mathrm{Cu}(\mathrm{Pip})_{2}(2-\mathrm{Bzpy})\right]_{2}(\mathbf{7})$ in MeOH $(\mathbf{1}-\mathbf{5}, \mathbf{7})$ or DMF:MeOH $(1: 2.5)(6)\left(\right.$ aprox. $\left.1 \cdot 10^{-3} \mathrm{M}\right)$ at room temperature. 


\section{X-ray crystal structures}

For 2, the integration of the data using a monoclinic unit cell yielded a total of 8490 reflections to a maximum $\theta$ angle of $24.45^{\circ}$ ( $0.86 \AA$ resolution), of which 1954 were independent (average redundancy 4345 , completeness $\left.=99.1 \%, \mathrm{R}_{\mathrm{int}}=4.49 \%, \mathrm{R}_{\text {sig }}=3.88 \%\right)$ and $1752(89.66 \%)$ were greater than $2 \sigma\left(\mathrm{F}^{2}\right)$. The calculated minimum and maximum transmission coefficients (based on crystal size) are 0.6333 and 0.7451 . For 3 , the integration of the data using a monoclinic unit cell yielded a total of 32090 reflections to a maximum $\theta$ angle of $27.52^{\circ}$ ( $0.77 \AA$ resolution), of which 3576 were independent (average redundancy 8974, completeness $=99.5 \%, R_{\text {int }}=13.65 \%$, $\left.\mathrm{R}_{\text {sig }}=6.00 \%\right)$ and $2633(73.63 \%)$ were greater than $2 \sigma\left(\mathrm{F}^{2}\right)$. The calculated minimum and maximum transmission coefficients (based on crystal size) are 0.6731 and 0.7456 . For 4 , the integration of the data using a monoclinic unit cell yielded a total of 51462 reflections to a maximum $\theta$ angle of $21.48^{\circ}(0.97 \AA$ resolution), of which 1898 were independent (average redundancy 27114 , completeness $\left.=99.6 \%, \mathrm{R}_{\mathrm{int}}=6.91 \%, \mathrm{R}_{\text {sig }}=1.68 \%\right)$ and $1728(91.04 \%)$ were greater than $2 \sigma\left(\mathrm{F}^{2}\right)$. The calculated minimum and maximum transmission coefficients (based on crystal size) are 0.6930 and 0.7446 . For 5 , the integration of the data using a triclinic unit cell yielded a total of 29716 reflections to a maximum $\theta$ angle of $26.73^{\circ}$ ( $0.79 \AA$ resolution), of which 5397 were independent (average redundancy 5506, completeness $=99.6 \%, R_{\text {int }}=3.45 \%$, $\left.\mathrm{R}_{\text {sig }}=2.37 \%\right)$ and $4560(84.49 \%)$ were greater than $2 \sigma\left(\mathrm{F}^{2}\right)$. The calculated minimum and maximum transmission coefficients (based on crystal size) are 0.6940 and 0.7454 . For 6, the integration of the data using a triclinic unit cell yielded a total of 46464 reflections to a maximum $\theta$ angle of $30.56^{\circ}(0.70 \AA$ resolution), of which 6939 were independent (average redundancy 6696, completeness $\left.=99.6 \%, \mathrm{R}_{\mathrm{int}}=3.05 \%, \mathrm{R}_{\text {sig }}=2.16 \%\right)$ and $6069(87.46 \%)$ were greater than $2 \sigma\left(\mathrm{F}^{2}\right)$. The calculated minimum and maximum transmission coefficients (based on crystal size) 
are 0.6897 and 0.7461 . For 7 , the integration of the data using a monoclinic unit cell yielded a total of 122091 reflections to a maximum $\theta$ angle of $28.33^{\circ}$ ( $0.75 \AA$ resolution), of which 11916 were independent (average redundancy 10246, completeness $=99.4 \%, \mathrm{R}_{\text {int }}=4.95 \%, \mathrm{R}_{\mathrm{sig}}=2.36 \%$ ) and $9844(82.61 \%)$ were greater than $2 \sigma\left(\mathrm{F}^{2}\right)$. The calculated minimum and maximum transmission coefficients (based on crystal size) are 0.6985 and 0.7457 .

The structures were solved using the Bruker SHELXTL Software, package and refined using SHELX [1]. For 2, the final anisotropic full-matrix least-squares refinement on $\mathrm{F}^{2}$ with 159 variables converged at $\mathrm{R}_{1}=8.30 \%$, for the observed data and $\mathrm{wR}_{2}=22.72 \%$ for all data. For 3, the final anisotropic full-matrix least-squares refinement on $\mathrm{F}^{2}$ with 230 variables converged at $\mathrm{R}_{1}=5.17 \%$, for the observed data and $\mathrm{wR}_{2}=10.74 \%$ for all data. For 4 , the final anisotropic full-matrix least-squares refinement on $\mathrm{F}^{2}$ with 222 variables converged at R1 $=6.75 \%$, for the observed data and $\mathrm{wR}_{2}=18.12 \%$ for all data. For $\mathbf{5}$, the final anisotropic fullmatrix least-squares refinement on $\mathrm{F}^{2}$ with 359 variables converged at $\mathrm{R}_{1}=2.93 \%$, for the observed data and $\mathrm{wR}_{2}=7.61 \%$ for all data. For $\mathbf{6}$, the final anisotropic full-matrix least-squares refinement on $\mathrm{F}^{2}$ with 317 variables converged at $\mathrm{R}_{1}=4.27 \%$, for the observed data and $\mathrm{wR}_{2}$ $=11.19 \%$ for all data. For 7 , the final anisotropic full-matrix least-squares refinement on $\mathrm{F}^{2}$ with 685 variables converged at $\mathrm{R}_{1}=3.59 \%$, for the observed data and $\mathrm{wR}_{2}=9.76 \%$ for all data.

\section{References}

[1] G.M. Sheldrick, Acta Cryst. 2015, C71, 3-8. 


\section{checkCIF/PLATON report}

Structure factors have been supplied for datablock(s) mo_c20vb25_0m_aa

THIS REPORT IS FOR GUIDANCE ONLY. IF USED AS PART OF A REVIEW PROCEDURE FOR PUBLICATION, IT SHOULD NOT REPLACE THE EXPERTISE OF AN EXPERIENCED CRYSTALLOGRAPHIC REFEREE.

No syntax errors found. CIF dictionary Interpreting this report

\section{Datablock: mo_c20vb25_0m_aa}

\begin{tabular}{|c|c|c|c|c|}
\hline Bond precision: & $\mathrm{C}-\mathrm{C}=0.0128$ & A & Wavelengt $h=0$ & 0.71073 \\
\hline Cell: & $\begin{array}{l}a=15.530(3) \\
\text { alpha }=90\end{array}$ & & $\begin{array}{l}\mathrm{b}=6.1225(12) \\
\text { bet } a=91.533(6)\end{array}$ & $\begin{array}{l}C=25.132(5) \\
\text { gamma }=90\end{array}$ \\
\hline \multirow[t]{2}{*}{ Temperature: } & $100 \mathrm{~K}$ & & & \\
\hline & Calculated & & Reported & \\
\hline Volume & $2388.8(8)$ & & $2388.7(8)$ & \\
\hline Space group & C $2 / \mathrm{C}$ & & C $2 / c$ & \\
\hline Hall group & $:-\mathrm{C} 2 \mathrm{yc}$ & & $-c 2 y c$ & \\
\hline Moiety formula & $\mathrm{C} 26 \mathrm{H} 22 \mathrm{Cu}$ N2 & 09 & $\mathrm{C} 26 \mathrm{H} 22 \mathrm{Cu}$ & N2 O9 \\
\hline Sum formula & $\mathrm{C} 26 \mathrm{H} 22 \mathrm{Cu}$ N2 & 09 & $\mathrm{C} 26 \mathrm{H} 22 \mathrm{Cu}$ & N2 O9 \\
\hline $\mathrm{Mr}$ & 570.01 & & 569.99 & \\
\hline $\mathrm{Dx}, \mathrm{gcm}-3$ & 1.585 & & 1.585 & \\
\hline $\mathrm{Z}$ & 4 & & 4 & \\
\hline $\mathrm{Mu} \quad(\mathrm{mm}-1)$ & 0.975 & & 0.975 & \\
\hline $\mathrm{F} 000$ & 1172.0 & & 1172.0 & \\
\hline F000' & 1173.86 & & & \\
\hline$h, k, l$ max & $18,7,29$ & & $18,7,29$ & \\
\hline Nref & 1970 & & 1953 & \\
\hline $\operatorname{Tmin}, \operatorname{Tmax}$ & $0.929,0.941$ & & $0.633,0.745$ & \\
\hline Tmin' & 0.749 & & & \\
\hline \multicolumn{2}{|c|}{$\begin{array}{l}\text { Correction method= \# Reported } \\
\text { AbsCorr = MULTI-SCAN }\end{array}$} & $\mathrm{T}$ & Limits: $\operatorname{Tmin}=0.633 \mathrm{Tm}$ & $\max =0.745$ \\
\hline \multicolumn{3}{|c|}{ Data completeness $=0.991$} & \multicolumn{2}{|l|}{ Theta $(\max )=24.446$} \\
\hline \multicolumn{3}{|c|}{$R($ reflections $)=0.0853(1751)$} & $\mathrm{wR} 2($ reflections $)=0$ & $0.2320(1953$ \\
\hline$S=1.117$ & Npa & & 135 & \\
\hline
\end{tabular}

The following ALERTS were generated. Each ALERT has the format test-name_ALERT_alert-type_alert-level.

Click on the hyperlinks for more details of the test. 
Alert level $\mathrm{C}$

DIFMX02_ALERT_1_C The maximum difference density is > 0.1 \#MAX*0.75

The relevant atom site should be identified.

THETM01_ALERT_3_C The value of sine(theta_max)/wavelength is less than 0.590

$$
\text { Calculated sin(theta_max)/wavelength }=0.5823
$$

PLAT097_ALERT_2_C Large Reported Max. (Positive) Residual Density

PLAT220_ALERT_2_C Non-Solvent Resd 1 C Ueq(max)/Ueq(min) Range

PLAT220_ALERT_2_C Non-Solvent Resd 10 Ueq (max)/Ueq(min) Range

PLAT222_ALERT_3_C Non-Solv. Resd 1 H Uiso(max)/Uiso(min) Range

PLAT232_ALERT_2_C Hirshfeld Test Diff (M-X) Cu1 -

PLAT234_ALERT_4_C Large Hirshfeld Difference O3 -

PLAT241_ALERT_2_C High 'MainMol' Ueq as Compared to Neighbors of

PLAT250_ALERT_2_C Large U3/U1 Ratio for Average U(i,j) Tensor ....

PLAT334_ALERT_2_C Small Aver. Benzene C-C Dist C7 -C12

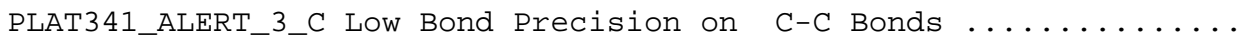

PLAT906_ALERT_3_C Large $K$ Value in the Analysis of Variance ......

PLAT911_ALERT_3_C Missing FCF Refl Between Thmin \& STh/L= 0.582

PLAT971_ALERT_2_C Check Calcd Resid. Dens. 0.11A From C7

PLAT971_ALERT_2_C Check Calcd Resid. Dens. 1.06A From Cu1

PLAT971_ALERT_2_C Check Calcd Resid. Dens. 0.04A From N1

PLAT972_ALERT_2_C Check Calcd Resid. Dens. 0.10A From C9

PLAT977_ALERT_2_C Check Negative Difference Density on H4

PLAT978_ALERT_2_C Number C-C Bonds with Positive Residual Density.

2.32 eA-3

3.4 Ratio

4.3 Ratio

6.3 Ratio

$5.2 \mathrm{~s} . \mathrm{u}$.

0.18 Ang.

O4 Check

2.2 Note

1.37 Ang.

0.01282 Ang.

3.568 Check

15 Report

2.50 eA-3

$2.07 \mathrm{eA}-3$

$1.71 \mathrm{eA}-3$

-1.87 eA-3

-0.40 eA-3

0 Info

\section{Alert level G}

PLAT002_ALERT_2_G Number of Distance or Angle Restraints on AtSite PLAT083_ALERT_2_G SHELXL Second Parameter in WGHT Unusually Large PLAT171_ALERT_4_G The CIF-Embedded.res File Contains EADP Records PLAT172_ALERT_4_G The CIF-Embedded.res File Contains DFIX Records PLAT398_ALERT_2_G Deviating C-O-C Angle From 120 for 03 PLAT398_ALERT_2_G Deviating C-O-C Angle From 120 for 04 PLAT794 ALERT 5_G Tentative Bond Valency for Cul PLAT860_ALERT_3_G Number of Least-Squares Restraints ........... PLAT909_ALERT_3_G Percentage of I>2sig(I) Data at Theta(Max) Still PLAT910_ALERT_3_G Missing \# of FCF Reflection(s) Below Theta(Min). PLAT913_ALERT_3_G Missing \# of Very Strong Reflections in FCF .... PLAT933_ALERT_2_G Number of OMIT Records in Embedded.res File... PLAT955_ALERT_1_G Reported (CIF) and Actual (FCF) Lmax Differ by .

2 Note

78.16 Why ?

2 Report

1 Report

106.2 Degree 108.1 Degree

2.16 Info

1 Note

$75 \%$ Note

2 Note

1 Note

1 Note

1 Units

0 ALERT level $\mathbf{A}=$ Most likely a serious problem - resolve or explain

0 ALERT level B $=$ A potentially serious problem, consider carefully

20 ALERT level $\mathbf{C}=$ Check. Ensure it is not caused by an omission or oversight

13 ALERT level $\mathbf{G}=$ General information/check it is not something unexpected

2 ALERT type 1 CIF construction/syntax error, inconsistent or missing data

18 ALERT type 2 Indicator that the structure model may be wrong or deficient

9 ALERT type 3 Indicator that the structure quality may be low

3 ALERT type 4 Improvement, methodology, query or suggestion

1 ALERT type 5 Informative message, check 
It is advisable to attempt to resolve as many as possible of the alerts in all categories. Often the minor alerts point to easily fixed oversights, errors and omissions in your CIF or refinement strategy, so attention to these fine details can be worthwhile. In order to resolve some of the more serious problems it may be necessary to carry out additional measurements or structure refinements. However, the purpose of your study may justify the reported deviations and the more serious of these should normally be commented upon in the discussion or experimental section of a paper or in the "special_details" fields of the CIF. checkCIF was carefully designed to identify outliers and unusual parameters, but every test has its limitations and alerts that are not important in a particular case may appear. Conversely, the absence of alerts does not guarantee there are no aspects of the results needing attention. It is up to the individual to critically assess their own results and, if necessary, seek expert advice.

\section{Publication of your CIF in IUCr journals}

A basic structural check has been run on your CIF. These basic checks will be run on all CIFs submitted for publication in IUCr journals (Acta Crystallographica, Journal of Applied Crystallography, Journal of Synchrotron Radiation); however, if you intend to submit to Acta Crystallographica Section C or E or IUCrData, you should make sure that full publication checks are run on the final version of your CIF prior to submission.

\section{Publication of your CIF in other journals}

Please refer to the Notes for Authors of the relevant journal for any special instructions relating to CIF submission.

\section{PLATON version of 26/09/2018; check.def file version of 13/09/2018}


Datablock mo_c20vb25_0m_aa - ellipsoid plot

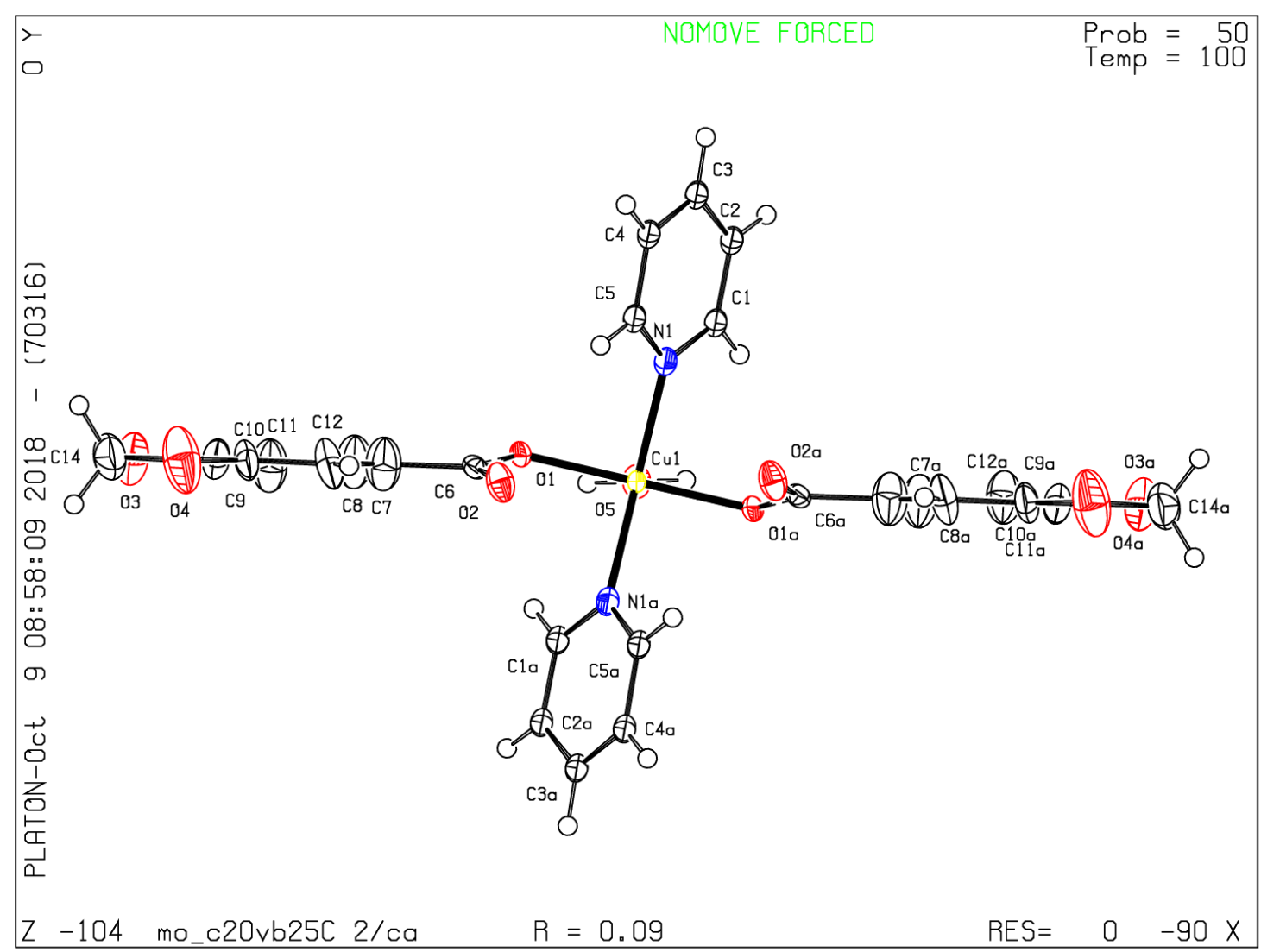




\section{checkCIF/PLATON report}

Structure factors have been supplied for datablock(s) mo_C20VB71A_0ma_a

THIS REPORT IS FOR GUIDANCE ONLY. IF USED AS PART OF A REVIEW PROCEDURE FOR PUBLICATION, IT SHOULD NOT REPLACE THE EXPERTISE OF AN EXPERIENCED CRYSTALLOGRAPHIC REFEREE.

No syntax errors found. CIF dictionary Interpreting this report

\section{Datablock: mo_C20VB71A_0ma_a}

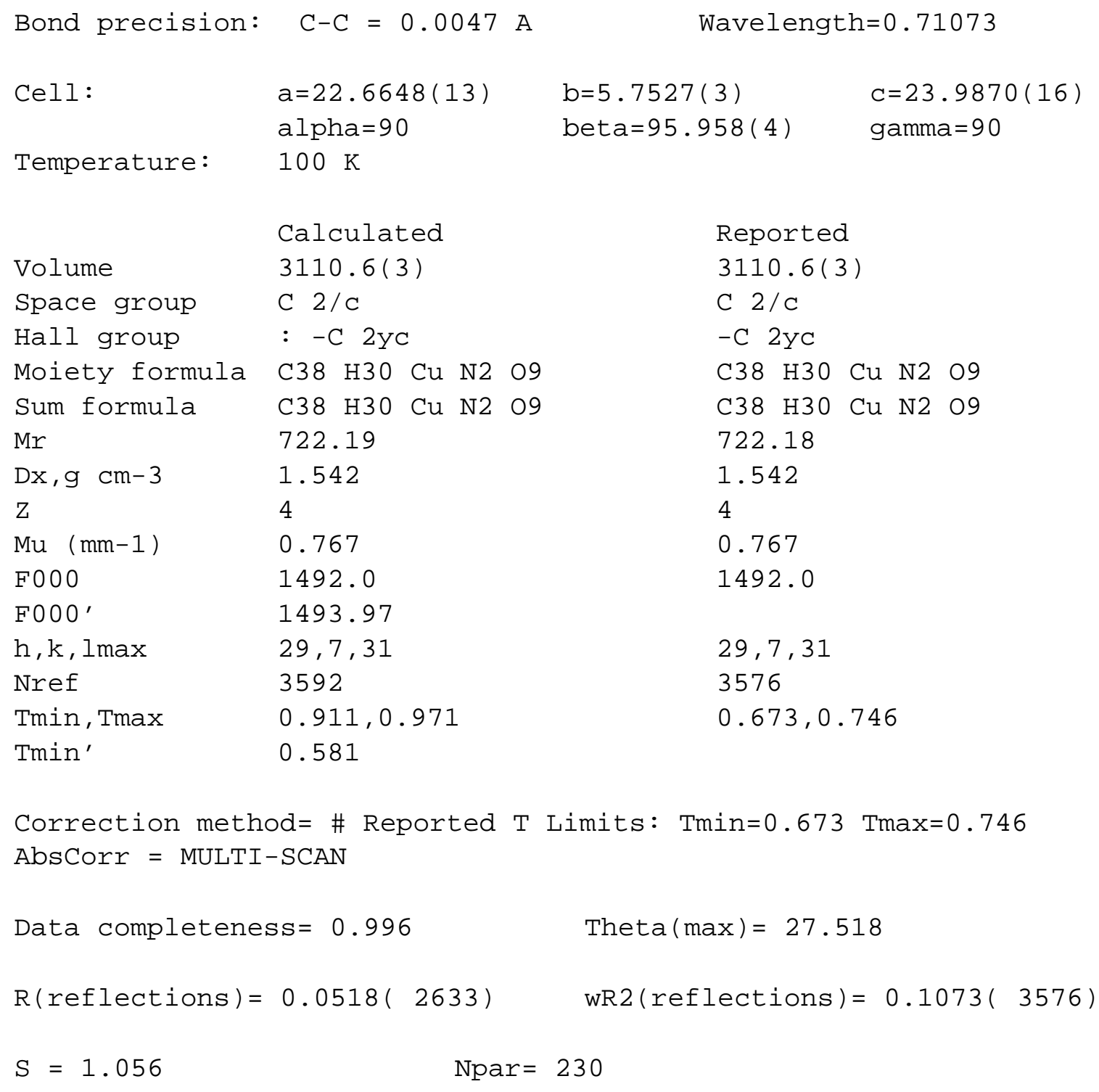


Alert level $\mathrm{C}$

RINTA01_ALERT_3_C The value of Rint is greater than 0.12

Rint given 0.137

PLAT906_ALERT_3_C Large $K$ Value in the Analysis of Variance ...... 3.051 Check

Alert level $\mathbf{G}$

PLAT002_ALERT_2_G Number of Distance or Angle Restraints on AtSite

2 Note

PLAT020_ALERT_3_G The Value of Rint is Greater Than $0.12 \ldots \ldots \ldots$

PLAT063_ALERT_4_G Crystal Size Likely too Large for Beam Size....

PLAT083_ALERT_2_G SHELXL Second Parameter in WGHT Unusually Large

PLAT172_ALERT_4_G The CIF-Embedded .res File Contains DFIX Records

PLAT398_ALERT_2_G Deviating C-O-C Angle From 120 for 03

PLAT398 ALERT $2 \mathrm{G}$ Deviating C-O-C Angle From 120 for 04

PLAT794_ALERT_5_G Tentative Bond Valency for Cul .

PLAT860_ALERT_3_G Number of Least-Squares Restraints ..........

PLAT910_ALERT_3_G Missing \# of FCF Reflection(s) Below Theta(Min).

PLAT912_ALERT_4_G Missing \# of FCF Reflections Above STh/L=0.600

PLAT955_ALERT_1_G Reported (CIF) and Actual (FCF) Lmax Differ by.

PLAT978_ALERT_2_G Number C-C Bonds with Positive Residual Density.

0.137 Report

$0.71 \mathrm{~mm}$

14.96 Why ?

1 Report

104.6 Degree

103.7 Degree

2.18 Info

1 Note

2 Note

15 Note

1 Units

2 Info

0 ALERT level $\mathbf{A}=$ Most likely a serious problem - resolve or explain

0 ALERT level $\mathbf{B}=\mathrm{A}$ potentially serious problem, consider carefully

2 ALERT level $\mathbf{C}=$ Check. Ensure it is not caused by an omission or oversight

13 ALERT level $\mathbf{G}=$ General information/check it is not something unexpected

1 ALERT type 1 CIF construction/syntax error, inconsistent or missing data

5 ALERT type 2 Indicator that the structure model may be wrong or deficient

5 ALERT type 3 Indicator that the structure quality may be low

3 ALERT type 4 Improvement, methodology, query or suggestion

1 ALERT type 5 Informative message, check 
It is advisable to attempt to resolve as many as possible of the alerts in all categories. Often the minor alerts point to easily fixed oversights, errors and omissions in your CIF or refinement strategy, so attention to these fine details can be worthwhile. In order to resolve some of the more serious problems it may be necessary to carry out additional measurements or structure refinements. However, the purpose of your study may justify the reported deviations and the more serious of these should normally be commented upon in the discussion or experimental section of a paper or in the "special_details" fields of the CIF. checkCIF was carefully designed to identify outliers and unusual parameters, but every test has its limitations and alerts that are not important in a particular case may appear. Conversely, the absence of alerts does not guarantee there are no aspects of the results needing attention. It is up to the individual to critically assess their own results and, if necessary, seek expert advice.

\section{Publication of your CIF in IUCr journals}

A basic structural check has been run on your CIF. These basic checks will be run on all CIFs submitted for publication in IUCr journals (Acta Crystallographica, Journal of Applied Crystallography, Journal of Synchrotron Radiation); however, if you intend to submit to Acta Crystallographica Section C or E or IUCrData, you should make sure that full publication checks are run on the final version of your CIF prior to submission.

\section{Publication of your CIF in other journals}

Please refer to the Notes for Authors of the relevant journal for any special instructions relating to CIF submission.

\section{PLATON version of 26/09/2018; check.def file version of 13/09/2018}


Datablock mo_C20VB71A_0ma_a - ellipsoid plot

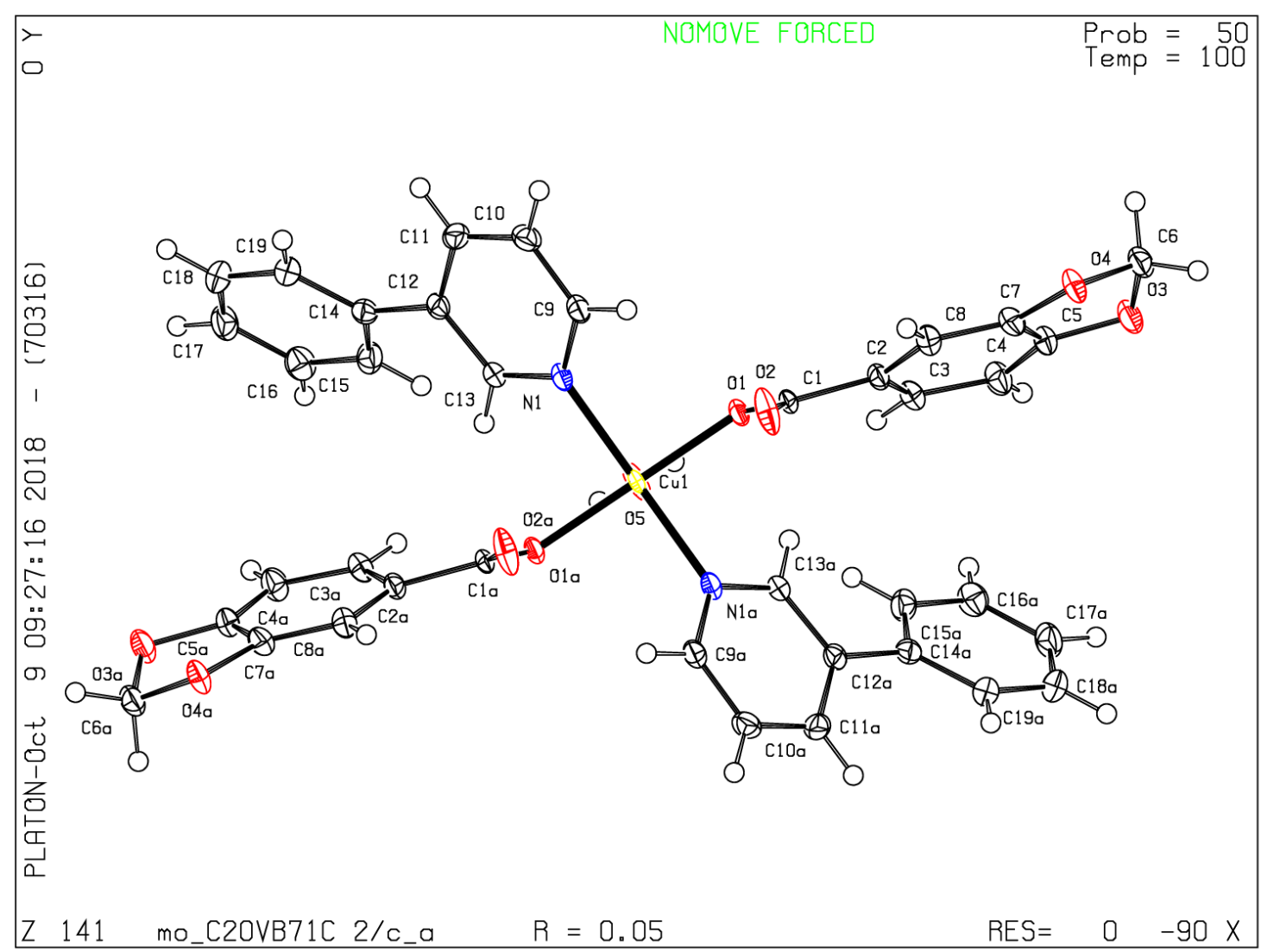




\section{checkCIF/PLATON report}

Structure factors have been supplied for datablock(s) mo_C20VB192_0m_a

THIS REPORT IS FOR GUIDANCE ONLY. IF USED AS PART OF A REVIEW PROCEDURE FOR PUBLICATION, IT SHOULD NOT REPLACE THE EXPERTISE OF AN EXPERIENCED CRYSTALLOGRAPHIC REFEREE.

No syntax errors found. CIF dictionary Interpreting this report

\section{Datablock: mo_C20VB192_0m_a}

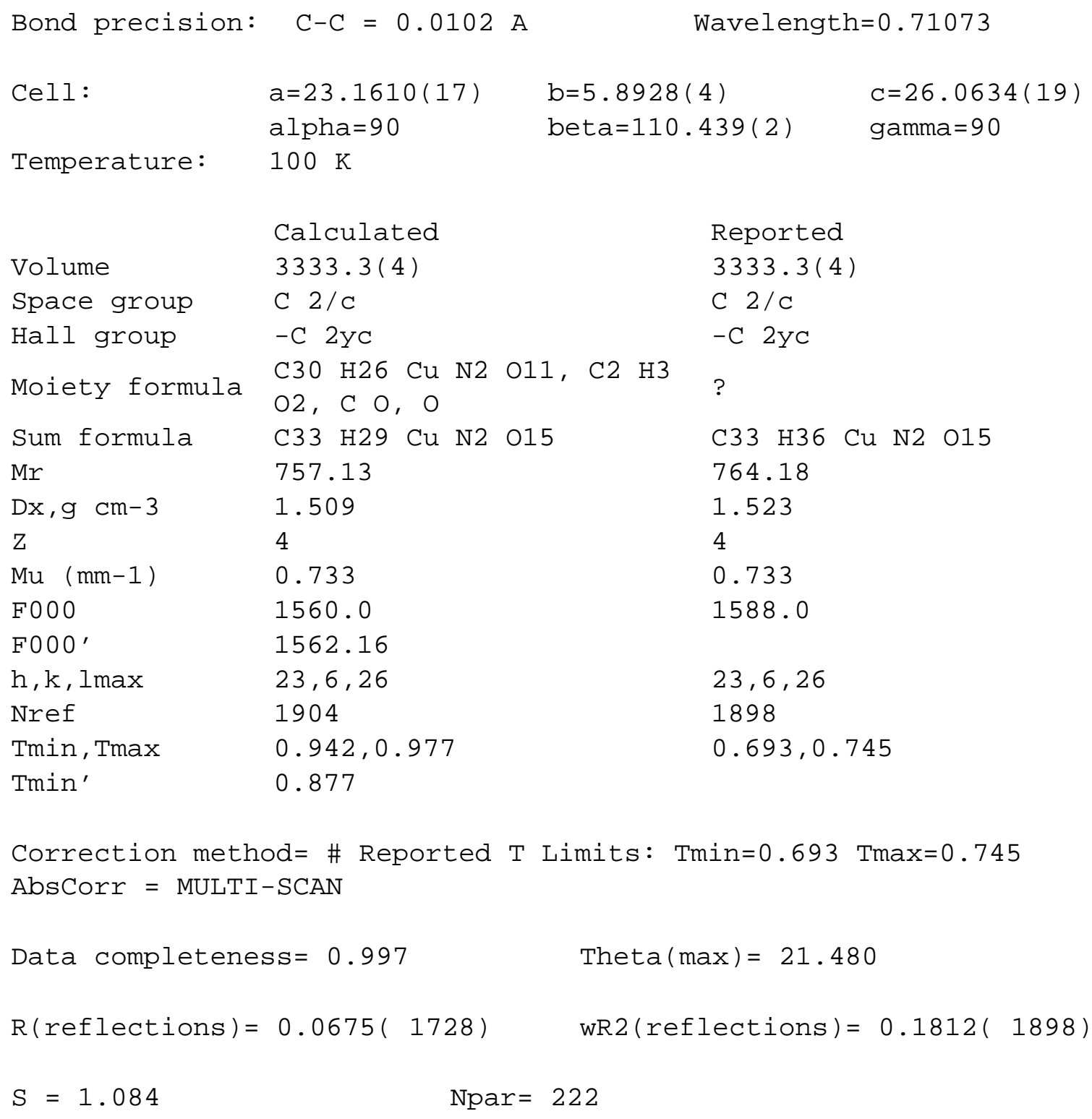


The following ALERTS were generated. Each ALERT has the format

test-name_ALERT_alert-type_alert-level.

Click on the hyperlinks for more details of the test.

\section{Alert level A}

THETM01_ALERT_3_A The value of sine(theta_max)/wavelength is less than 0.550

$$
\text { Calculated sin(theta_max)/wavelength }=0.5152
$$

Alert level $\mathrm{C}$

REFNR01_ALERT_3_C Ratio of reflections to parameters is < 10 for a centrosymmetric structure

sine (theta)/lambda 0.5152

Proportion of unique data used 1.0000

Ratio reflections to parameters 8.5495

PLAT018_ALERT_1_C_diffrn_measured_fraction_theta_max .NE. *_full

PLAT041_ALERT_1_C Calc. and Reported SumFormula Strings Differ

PLAT043_ALERT_1_C Calculated and Reported Mol. Weight Differ by ..

PLAT068_ALERT_1_C Reported F000 Differs from Calcd (or Missing)...

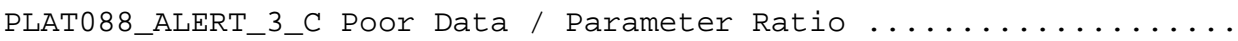

PLAT094_ALERT_2_C Ratio of Maximum / Minimum Residual Density ....

PLAT213_ALERT_2_C Atom O5W has ADP max/min Ratio.....

PLAT220_ALERT_2_C Non-Solvent Resd 1 C Ueq(max)/Ueq(min) Range

PLAT220_ALERT_2_C Non-Solvent Resd 10 Ueq(max)/Ueq(min) Range

PLAT222_ALERT_3_C Non-Solv. Resd 1 H Uiso(max)/Uiso(min) Range

PLAT250_ALERT_2_C Large U3/U1 Ratio for Average U(i,j) Tensor .....

PLAT309_ALERT_2_C Single Bonded Oxygen (C-O > 1.3 Ang) ........

PLAT309_ALERT_2_C Single Bonded Oxygen ( $\mathrm{C}-\mathrm{O}>1.3$ Ang) $\ldots . . . .$.

PLAT309_ALERT_2_C Single Bonded Oxygen ( $\mathrm{C}-\mathrm{O}>1.3$ Ang) $\ldots . . . \ldots$

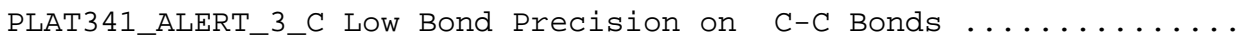

PLAT911_ALERT_3_C Missing FCF Refl Between Thmin \& STh/L= 0.515

PLAT939_ALERT_3_C Large Value of Not (SHELXL) Weight Optimized S.

PLAT971_ALERT_2_C Check Calcd Resid. Dens. 1.14A From C3W

$$
\begin{aligned}
\text { ! Check } \\
\text { Please Check } \\
7.05 \text { Check } \\
\text { Please Check } \\
8.55 \text { Note } \\
2.13 \text { Report } \\
4.0 \text { prolat } \\
4.5 \text { Ratio } \\
5.0 \text { Ratio } \\
4.9 \text { Ratio } \\
2.4 \text { Note } \\
\text { C1W Check } \\
\text { 03W Check } \\
\text { O4W Check } \\
01015 \text { Ang. } \\
4 \text { Report } \\
10.12 \text { Check } \\
1.61 \text { eA-3 }
\end{aligned}
$$

\section{Alert level G}

FORMU01_ALERT_2_G There is a discrepancy between the atom counts in the

_chemical_formula_sum and the formula from the _atom_site* data.

Atom count from_chemical_formula_sum:C33 H36 Cu1 N2 015

Atom count from the _atom_site data: C33 H29 Cu1 N2 015

CELLZ01_ALERT_1_G Difference between formula and atom_site contents detected.

CELLZ01_ALERT_1_G WARNING: H atoms missing from atom site list. Is this intentional?

From the CIF:_cell_formula_units_Z 4

From the CIF: _chemical_formula_sum C33 H36 Cu N2 015

TEST: Compare cell contents of formula and atom_site data

$\begin{array}{lcrr}\text { atom } & \text { Z*formula } & \text { cif sites diff } \\ \mathrm{C} & 132.00 & 132.00 & 0.00 \\ \mathrm{H} & 144.00 & 116.00 & 28.00 \\ \mathrm{Cu} & 4.00 & 4.00 & 0.00 \\ \mathrm{~N} & 8.00 & 8.00 & 0.00 \\ \mathrm{O} & 60.00 & 60.00 & 0.00\end{array}$

PLAT002_ALERT_2_G Number of Distance or Angle Restraints on AtSite

PLAT017_ALERT_1_G Check Scattering Type Consistency of C1W as

PLAT017_ALERT_1_G Check Scattering Type Consistency of O1W as

PLAT083_ALERT_2_G SHELXL Second Parameter in WGHT Unusually Large

PLAT171_ALERT_4_G The CIF-Embedded .res File Contains EADP Records

PLAT172_ALERT_4_G The CIF-Embedded.res File Contains DFIX Records

PLAT300_ALERT_4_G Atom Site Occupancy of C1W Constrained at

PLAT300_ALERT_4_G Atom Site Occupancy of O3W Constrained at

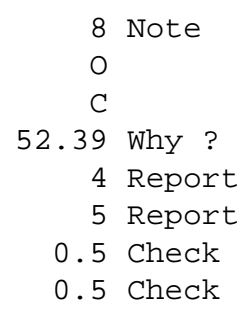




\begin{tabular}{|c|c|c|c|}
\hline PLAT300_ALERT_4_G & Atom Site Occupancy of C3W & 0.5 & Check \\
\hline PLAT300_ALERT_4_G & Atom Site Occupancy of H3WA & 0.5 & Check \\
\hline PLAT300_ALERT_4_G & Atom Site Occupancy of H3WB & 0.5 & Check \\
\hline PLAT300_ALERT_4_G & Atom Site Occupancy of H3WC & 0.5 & \\
\hline PLAT300_ALERT_4_G & Atom Site Occupancy of $04 \mathrm{~W}$ & 0.5 & \\
\hline PLAT300_ALERT_4_G & tom Site Occupancy of $\mathrm{C} 4 \mathrm{~W}$ & 0.5 & \\
\hline PLAT300_ALERT_4_G & Atom Site Occupancy of $02 \mathrm{~W}$ & 0.5 & eck \\
\hline PLAT302_ALERT_4_G & nion/Solvent/Minor-Residue Disorder (Resd 2 & $75 \%$ & Jote \\
\hline PLAT302_ALERT_4_G & nion/Solvent/Minor-Residue Disorder (Resd & $100 \%$ & Jote \\
\hline PLAT302_ALERT_4_G & Anion/Solvent/Minor-Residue Disorder (Resd & $100 \%$ & Not \\
\hline PLAT304_ALERT_4_G & Non-Integer Number of Atoms in ..... Resd & 0.50 & \\
\hline PLAT311_ALERT_2_G & Isolated Disordered Oxygen Atom (No H's ?) & $\mathrm{O} 2 \mathrm{~W}$ & $\mathrm{Ch}$ \\
\hline PLAT398_ALERT_2_G & Angle From 120 for 03 & 104.2 & \\
\hline PLAT398_ALERT_2_G & Angle From 120 for 04 & 104.2 & \\
\hline PLAT720_ALERT_4_G & Number of Unusual/Non-Standard Labels ..... & 5 & Not \\
\hline PLAT794_ALERT_5_G & Tentative Bond Valency for Cul & 2.18 & Info \\
\hline PLAT802_ALERT_4_G & CIF Input Record(s) with more than 80 Character & 1 & Info \\
\hline PLAT860_ALERT_3_G & Number of Least-Squares Restraints ........ & 5 & Note \\
\hline PLAT909_ALERT_3_G & Percentage of I>2sig(I) Data at Theta(Max) Stil & $33 \%$ & Note \\
\hline PLAT910_ALERT_3_G & Missing \# of FCF Reflection(s) Below Theta(Min) & & Note \\
\hline PLAT978_ALERT_2_G & Number $\mathrm{C}-\mathrm{C}$ Bonds with Positive Residual Density & & Info \\
\hline
\end{tabular}

1 ALERT level $\mathbf{A}=$ Most likely a serious problem - resolve or explain

0 ALERT level $\mathbf{B}=\mathrm{A}$ potentially serious problem, consider carefully

19 ALERT level $\mathbf{C}=$ Check. Ensure it is not caused by an omission or oversight

32 ALERT level $\mathbf{G}=$ General information/check it is not something unexpected

8 ALERT type 1 CIF construction/syntax error, inconsistent or missing data

16 ALERT type 2 Indicator that the structure model may be wrong or deficient

10 ALERT type 3 Indicator that the structure quality may be low

17 ALERT type 4 Improvement, methodology, query or suggestion

1 ALERT type 5 Informative message, check 
It is advisable to attempt to resolve as many as possible of the alerts in all categories. Often the minor alerts point to easily fixed oversights, errors and omissions in your CIF or refinement strategy, so attention to these fine details can be worthwhile. In order to resolve some of the more serious problems it may be necessary to carry out additional measurements or structure refinements. However, the purpose of your study may justify the reported deviations and the more serious of these should normally be commented upon in the discussion or experimental section of a paper or in the "special_details" fields of the CIF. checkCIF was carefully designed to identify outliers and unusual parameters, but every test has its limitations and alerts that are not important in a particular case may appear. Conversely, the absence of alerts does not guarantee there are no aspects of the results needing attention. It is up to the individual to critically assess their own results and, if necessary, seek expert advice.

\section{Publication of your CIF in IUCr journals}

A basic structural check has been run on your CIF. These basic checks will be run on all CIFs submitted for publication in IUCr journals (Acta Crystallographica, Journal of Applied Crystallography, Journal of Synchrotron Radiation); however, if you intend to submit to Acta Crystallographica Section C or E or IUCrData, you should make sure that full publication checks are run on the final version of your CIF prior to submission.

\section{Publication of your CIF in other journals}

Please refer to the Notes for Authors of the relevant journal for any special instructions relating to CIF submission.

\section{PLATON version of 30/01/2018; check.def file version of 30/01/2018}


Datablock mo_C20VB192_0m_a - ellipsoid plot

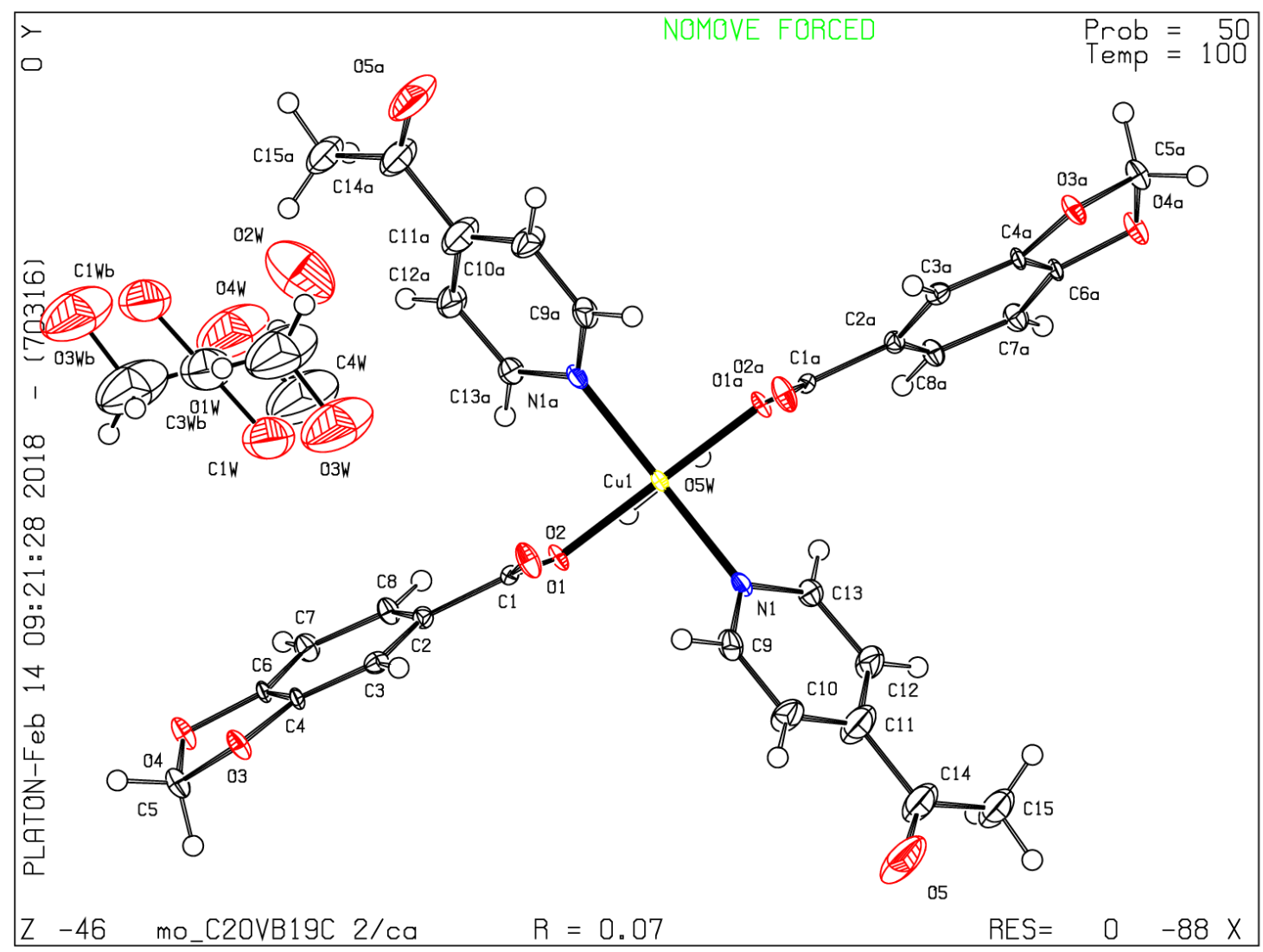




\section{checkCIF/PLATON report}

Structure factors have been supplied for datablock(s) mo_C20VB195_0m_a

THIS REPORT IS FOR GUIDANCE ONLY. IF USED AS PART OF A REVIEW PROCEDURE FOR PUBLICATION, IT SHOULD NOT REPLACE THE EXPERTISE OF AN EXPERIENCED CRYSTALLOGRAPHIC REFEREE.

No syntax errors found. CIF dictionary Interpreting this report

\section{Datablock: mo_C20VB195_0m_a}

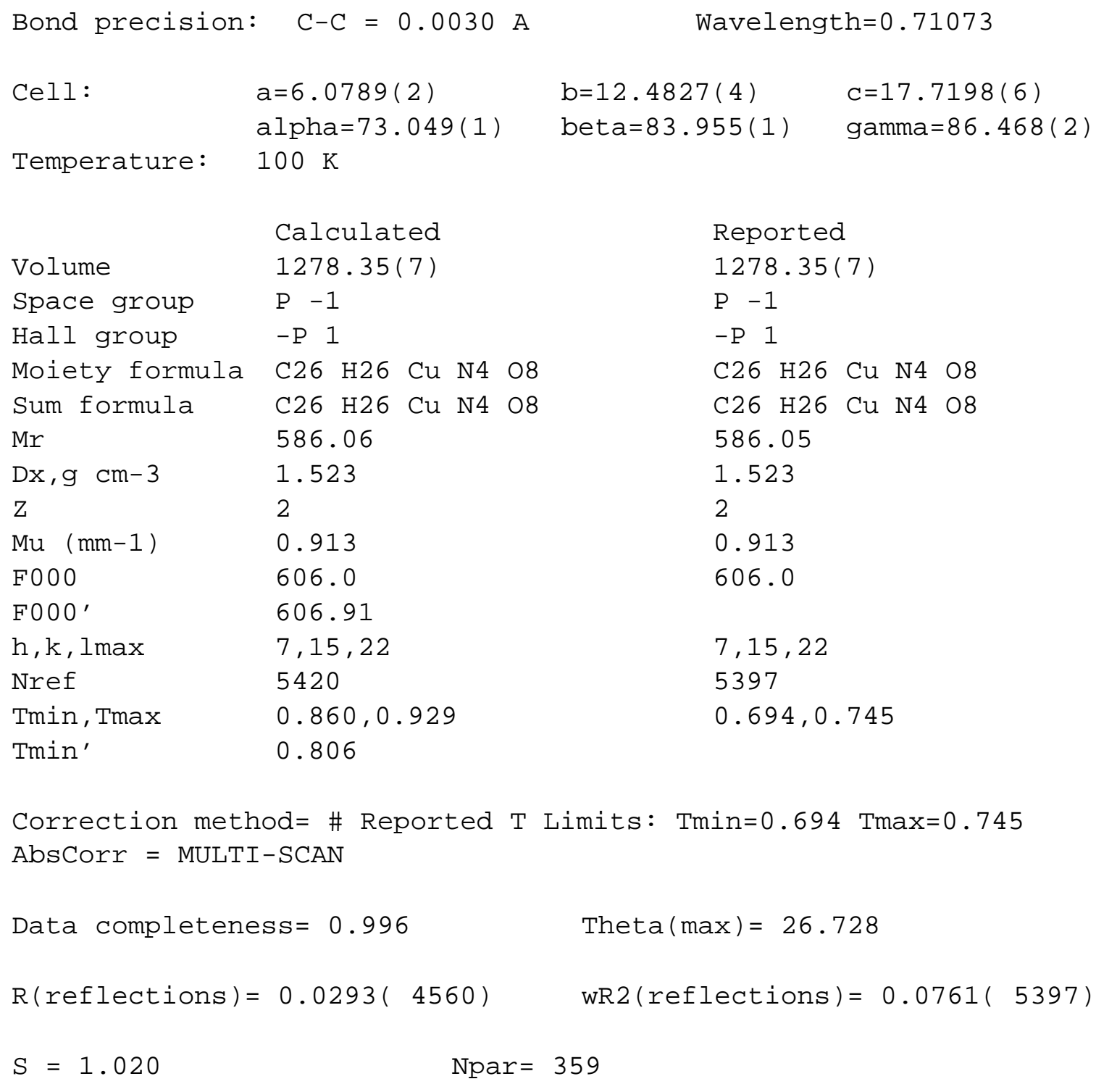


Alert level C

PLAT911_ALERT_3_C Missing \# FCF Refl Between THmin \& STh/L= $0.600 \quad 12$ Report

Alert level G

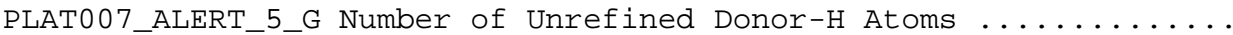

2 Report

PLAT398_ALERT_2_G Deviating C-O-C Angle from 120 Deg for O3A

PLAT398_ALERT_2_G Deviating C-O-C Angle from 120 Deg for O4A

PLAT398_ALERT_2_G Deviating C-O-C Angle from 120 Deg for O3B

PLAT398_ALERT_2_G Deviating C-O-C Angle from 120 Deg for O4B

PLAT720_ALERT_4_G Number of Unusual/Non-Standard Labels .........

PLAT794_ALERT_5_G Tentative Bond Valency for Cu1A (II) .....

PLAT794_ALERT_5_G Tentative Bond Valency for CulB (II) .....

PLAT910_ALERT_3_G Missing \# of FCF Reflection(s) Below Theta(Min).

PLAT912_ALERT_4_G Missing \# of FCF Reflections Above STh/L= 0.600

PLAT913_ALERT_3_G Missing \# of Very Strong Reflections in FCF ....

PLAT933_ALERT_2_G Number of OMIT Records in Embedded.res File...

PLAT978_ALERT_2_G Number C-C Bonds with Positive Residual Density.

105.1 Degree

104.7 Degree

105.8 Degree

105.7 Degree

4 Note

2.18 Info

2.34 Info

4 Note

7 Note

1 Note

1 Note

15 Info

0 ALERT level $\mathbf{A}=$ Most likely a serious problem - resolve or explain

0 ALERT level $\mathbf{B}=\mathrm{A}$ potentially serious problem, consider carefully

1 ALERT level $\mathbf{C}=$ Check. Ensure it is not caused by an omission or oversight

13 ALERT level $\mathbf{G}=$ General information/check it is not something unexpected

0 ALERT type 1 CIF construction/syntax error, inconsistent or missing data

6 ALERT type 2 Indicator that the structure model may be wrong or deficient

3 ALERT type 3 Indicator that the structure quality may be low

2 ALERT type 4 Improvement, methodology, query or suggestion

3 ALERT type 5 Informative message, check 
It is advisable to attempt to resolve as many as possible of the alerts in all categories. Often the minor alerts point to easily fixed oversights, errors and omissions in your CIF or refinement strategy, so attention to these fine details can be worthwhile. In order to resolve some of the more serious problems it may be necessary to carry out additional measurements or structure refinements. However, the purpose of your study may justify the reported deviations and the more serious of these should normally be commented upon in the discussion or experimental section of a paper or in the "special_details" fields of the CIF. checkCIF was carefully designed to identify outliers and unusual parameters, but every test has its limitations and alerts that are not important in a particular case may appear. Conversely, the absence of alerts does not guarantee there are no aspects of the results needing attention. It is up to the individual to critically assess their own results and, if necessary, seek expert advice.

\section{Publication of your CIF in IUCr journals}

A basic structural check has been run on your CIF. These basic checks will be run on all CIFs submitted for publication in IUCr journals (Acta Crystallographica, Journal of Applied Crystallography, Journal of Synchrotron Radiation); however, if you intend to submit to Acta Crystallographica Section C or E or IUCrData, you should make sure that full publication checks are run on the final version of your CIF prior to submission.

\section{Publication of your CIF in other journals}

Please refer to the Notes for Authors of the relevant journal for any special instructions relating to CIF submission.

\section{PLATON version of 13/08/2017; check.def file version of 27/07/2017}


Datablock mo_C20VB195_0m_a - ellipsoid plot

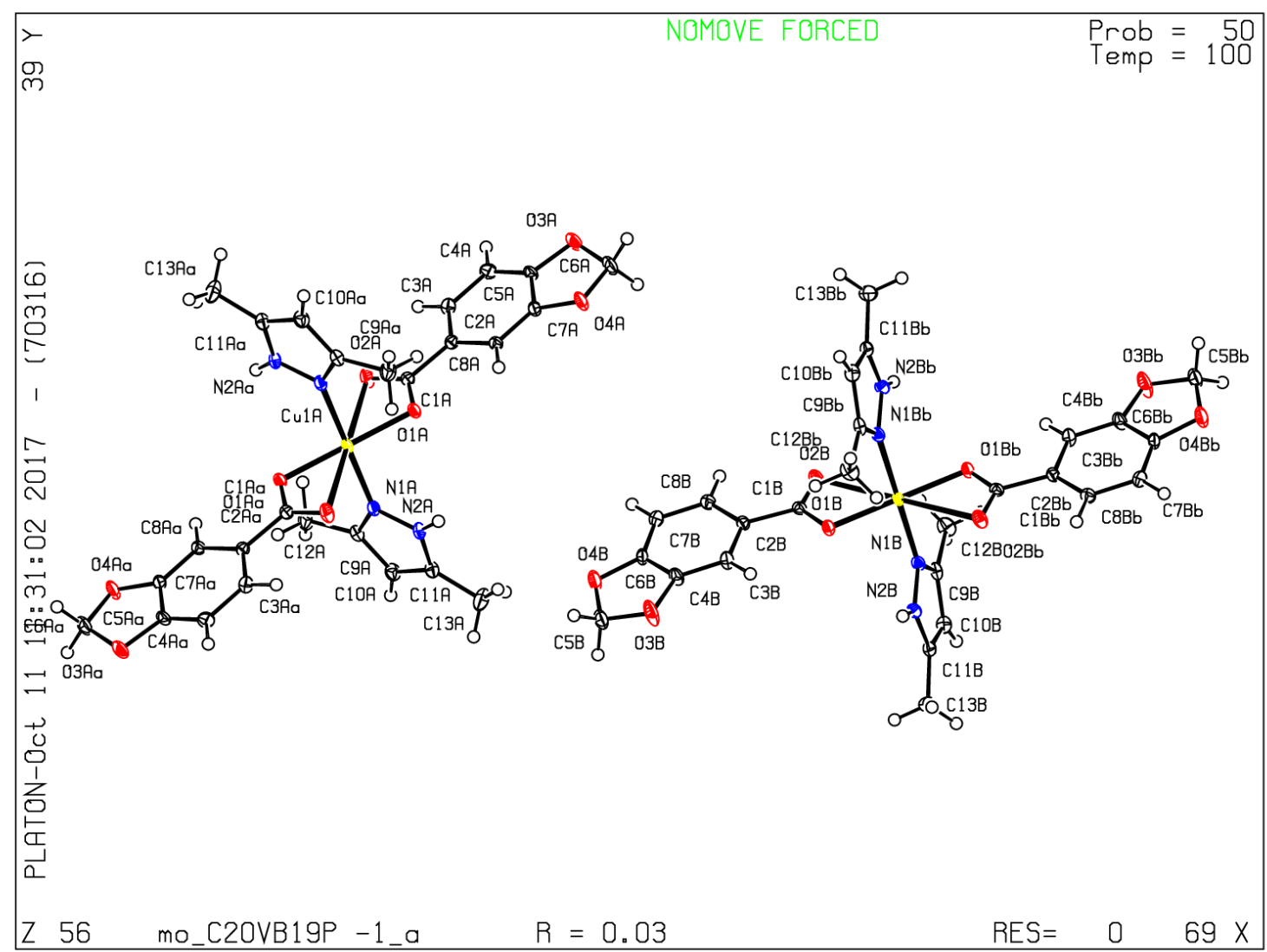




\section{checkCIF/PLATON report}

Structure factors have been supplied for datablock(s) mo_C20VB106_0m_a

THIS REPORT IS FOR GUIDANCE ONLY. IF USED AS PART OF A REVIEW PROCEDURE FOR PUBLICATION, IT SHOULD NOT REPLACE THE EXPERTISE OF AN EXPERIENCED CRYSTALLOGRAPHIC REFEREE.

No syntax errors found. CIF dictionary Interpreting this report

\section{Datablock: mo_C20VB106_0m_a}

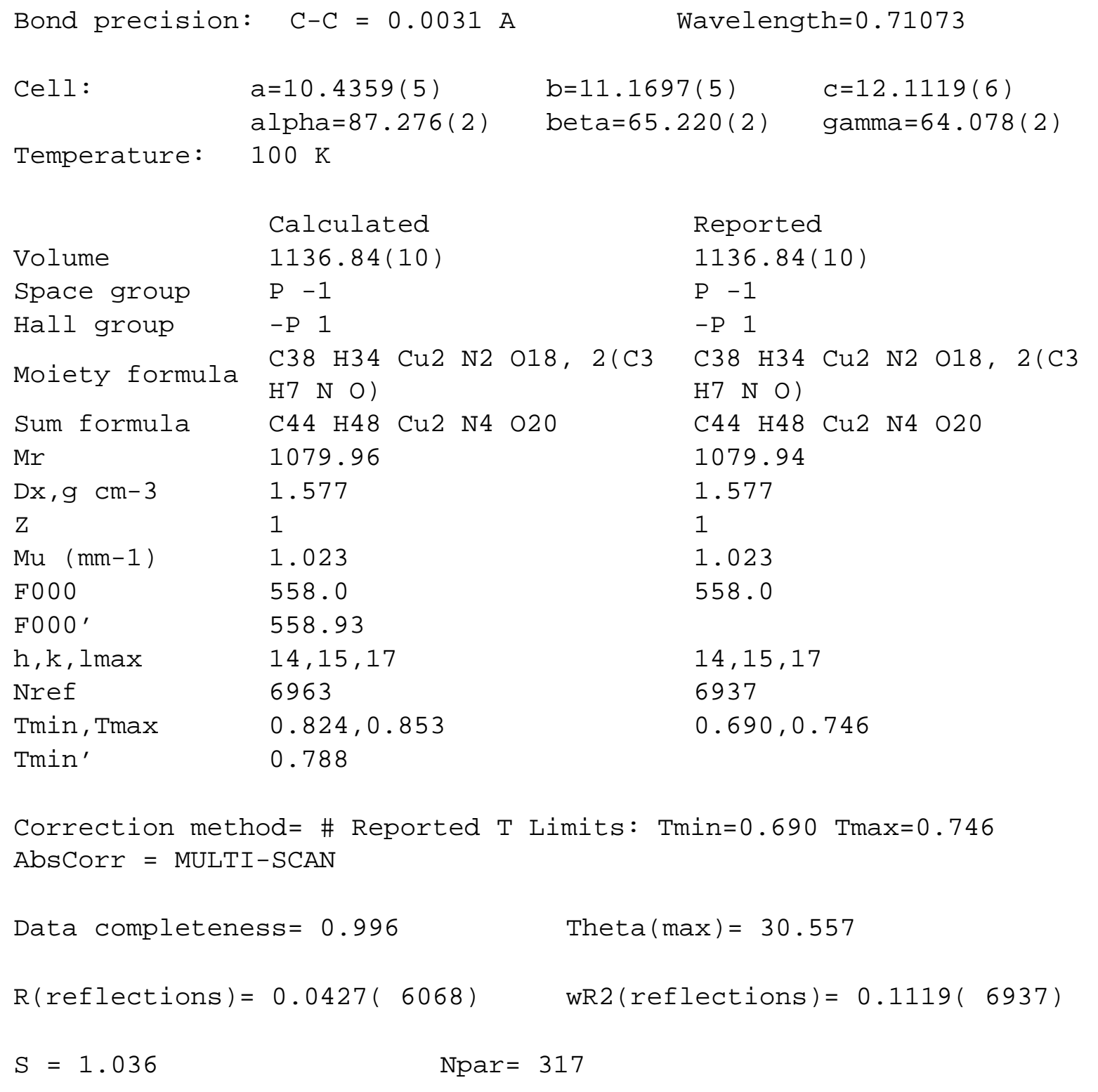


The following ALERTS were generated. Each ALERT has the format

test-name_ALERT_alert-type_alert-level.

Click on the hyperlinks for more details of the test.

Alert level C

PLAT220_ALERT_2_C Non-Solvent Resd 1 C Ueq(max)/Ueq(min) Range

PLAT244_ALERT_4_C Low 'Solvent' Ueq as Compared to Neighbors of

PLAT250_ALERT_2_C Large U3/U1 Ratio for Average U(i,j) Tensor ....

PLAT309_ALERT_2_C Single Bonded Oxygen ( $-\mathrm{O}>1.3 \mathrm{Ang}) \ldots . . . \ldots$

PLAT911_ALERT_3_C Missing FCF Refl Between Thmin \& STh/L= 0.600

PLAT913_ALERT_3_C Missing \# of Very Strong Reflections in FCF ....
3. 6 Ratio
N2 Check
2.8 Note
010' Check
10 Report
4 Note

\section{Alert level $\mathbf{G}$}

PLAT154_ALERT_1_G The s.u.'s on the Cell Angles are Equal .. (Note)

PLAT171_ALERT_4_G The CIF-Embedded.res File Contains EADP Records

PLAT300_ALERT_4_G Atom Site Occupancy of 010 Constrained at

PLAT300_ALERT_4_G Atom Site Occupancy of 010' Constrained at

PLAT302_ALERT_4_G Anion/Solvent/Minor-Residue Disorder (Resd 2 )

PLAT398_ALERT_2_G Deviating C-O-C Angle From 120 for 03

PLAT398_ALERT_2_G Deviating C-O-C Angle From 120 for 04

PLAT398_ALERT_2_G Deviating C-O-C Angle From 120 for 07

PLAT398_ALERT_2_G Deviating C-O-C Angle From 120 for 08

PLAT794_ALERT_5_G Tentative Bond Valency for Cul (II)

PLAT910_ALERT_3_G Missing \# of FCF Reflection(s) Below Theta(Min).

PLAT912_ALERT_4_G Missing \# of FCF Reflections Above STh/L= 0.600

PLAT933_ALERT_2_G Number of OMIT Records in Embedded.res File...

PLAT978_ALERT_2_G Number C-C Bonds with Positive Residual Density.
0.002 Degree
2 Report
0.5 Check
0.5 Check
20\% Note
106.5 Degree
105.0 Degree
106.1 Degree
106.2 Degree
2.11 Info
4 Note
12 Note
2 Note
8 Info

\footnotetext{
0 ALERT level $\mathbf{A}=$ Most likely a serious problem - resolve or explain

0 ALERT level $\mathbf{B}=\mathrm{A}$ potentially serious problem, consider carefully

6 ALERT level $\mathbf{C}=$ Check. Ensure it is not caused by an omission or oversight

14 ALERT level $\mathbf{G}=$ General information/check it is not something unexpected

1 ALERT type 1 CIF construction/syntax error, inconsistent or missing data

9 ALERT type 2 Indicator that the structure model may be wrong or deficient

3 ALERT type 3 Indicator that the structure quality may be low

6 ALERT type 4 Improvement, methodology, query or suggestion

1 ALERT type 5 Informative message, check
} 
It is advisable to attempt to resolve as many as possible of the alerts in all categories. Often the minor alerts point to easily fixed oversights, errors and omissions in your CIF or refinement strategy, so attention to these fine details can be worthwhile. In order to resolve some of the more serious problems it may be necessary to carry out additional measurements or structure refinements. However, the purpose of your study may justify the reported deviations and the more serious of these should normally be commented upon in the discussion or experimental section of a paper or in the "special_details" fields of the CIF. checkCIF was carefully designed to identify outliers and unusual parameters, but every test has its limitations and alerts that are not important in a particular case may appear. Conversely, the absence of alerts does not guarantee there are no aspects of the results needing attention. It is up to the individual to critically assess their own results and, if necessary, seek expert advice.

\section{Publication of your CIF in IUCr journals}

A basic structural check has been run on your CIF. These basic checks will be run on all CIFs submitted for publication in IUCr journals (Acta Crystallographica, Journal of Applied Crystallography, Journal of Synchrotron Radiation); however, if you intend to submit to Acta Crystallographica Section C or E or IUCrData, you should make sure that full publication checks are run on the final version of your CIF prior to submission.

\section{Publication of your CIF in other journals}

Please refer to the Notes for Authors of the relevant journal for any special instructions relating to CIF submission.

\section{PLATON version of 23/04/2018; check.def file version of 23/04/2018}


Datablock mo_C20VB106_0m_a - ellipsoid plot

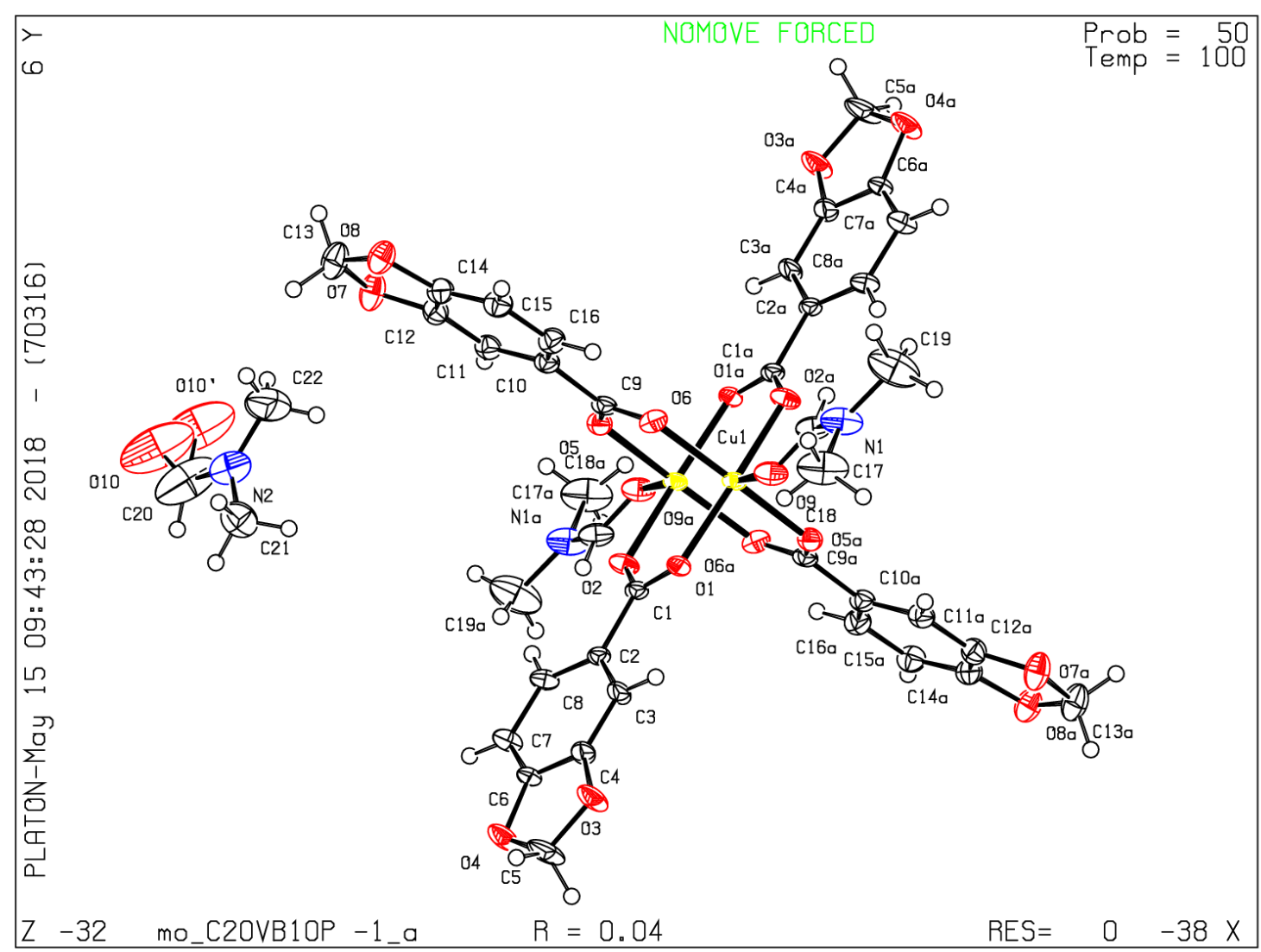




\section{checkCIF/PLATON report}

Structure factors have been supplied for datablock(s) mo_C20VB206_0ma_a

THIS REPORT IS FOR GUIDANCE ONLY. IF USED AS PART OF A REVIEW PROCEDURE FOR PUBLICATION, IT SHOULD NOT REPLACE THE EXPERTISE OF AN EXPERIENCED CRYSTALLOGRAPHIC REFEREE.

No syntax errors found. CIF dictionary Interpreting this report

\section{Datablock: mo_C20VB206_0ma_a}

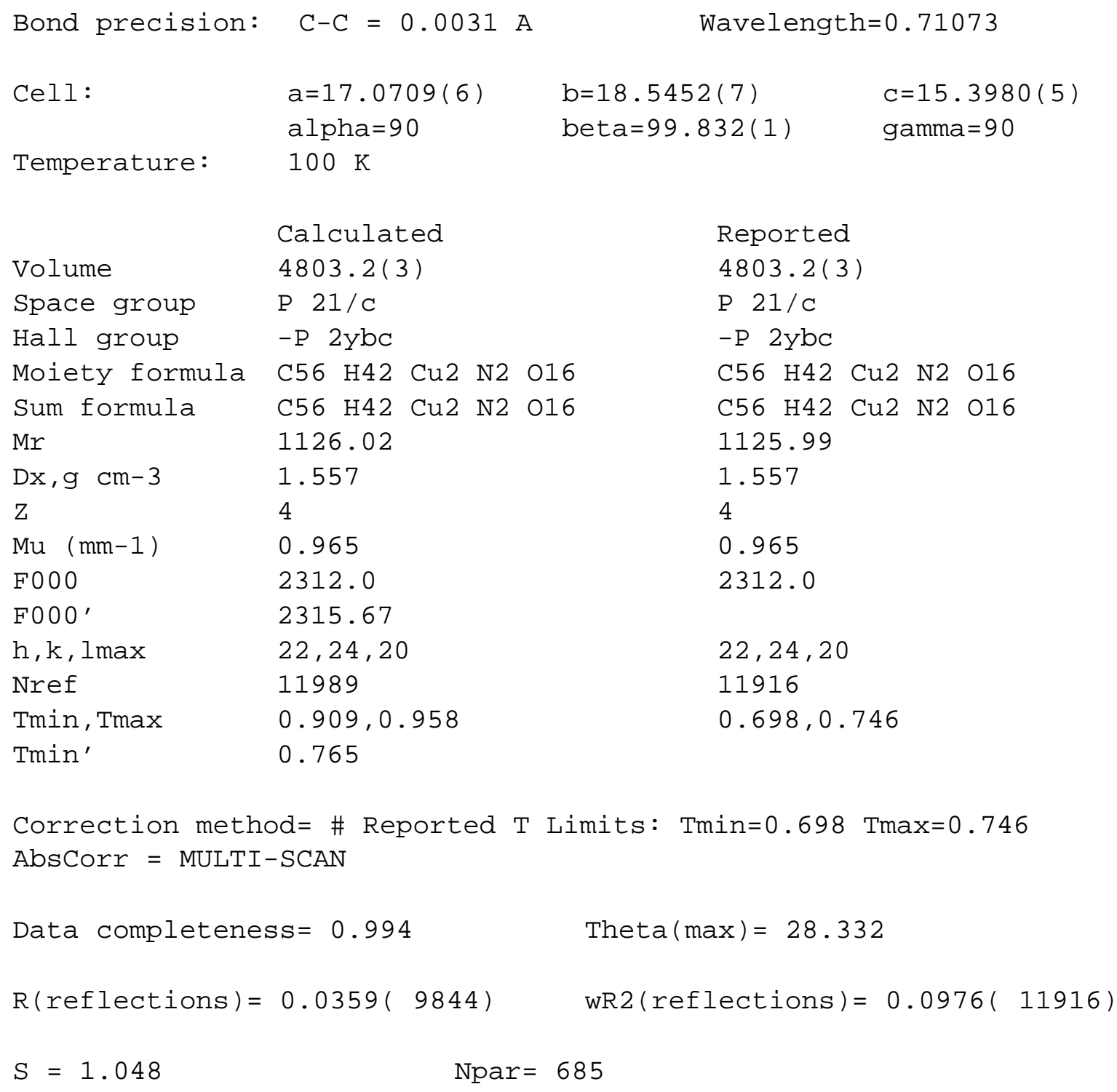


Alert level $\mathrm{C}$

PLAT220_ALERT_2_C Non-Solvent Resd 1 o Ueq (max)/Ueq(min) Range PLAT241_ALERT_2_C High 'MainMol' Ueq as Compared to Neighbors of PLAT241_ALERT_2_C High 'MainMol' Ueq as Compared to Neighbors of PLAT241_ALERT_2_C High 'MainMol' Ueq as Compared to Neighbors of PLAT910_ALERT_3_C Missing \# of FCF Reflection(s) Below Theta(Min). PLAT911_ALERT_3_C Missing FCF Refl Between Thmin \& STh/L $=0.600$ PLAT934_ALERT_3_C Number of (Iobs-Icalc)/SigmaW > 10 Outliers ....

3.2 Ratio

O3 Check

O4 Check

C18 Check

6 Note

49 Report

1 Check

Alert level $\mathbf{G}$

PLAT003_ALERT_2_G Number of Uiso or Uij Restrained non-H Atoms ... PLAT083_ALERT_2_G SHELXL Second Parameter in WGHT Unusually Large PLAT177_ALERT_4_G The CIF-Embedded.res File Contains DELU Records PLAT398_ALERT_2_G Deviating C-O-C Angle From 120 for 03

PLAT398_ALERT_2_G Deviating C-O-C Angle From 120 for 04

PLAT398_ALERT_2_G Deviating C-O-C Angle From 120 for 07

PLAT398_ALERT_2_G Deviating C-O-C Angle From 120 for 08

PLAT398_ALERT_2_G Deviating C-O-C Angle From 120 for 011

PLAT398_ALERT_2_G Deviating C-O-C Angle From 120 for 012

PLAT398_ALERT_2_G Deviating C-O-C Angle From 120 for 015

PLAT398_ALERT_2_G Deviating C-O-C Angle From 120 for 016

PLAT860_ALERT_3_G Number of Least-Squares Restraints ...........

PLAT912_ALERT_4_G Missing \# of FCF Reflections Above STh/L= 0.600

PLAT913_ALERT_3_G Missing \# of Very strong Reflections in FCF ....

PLAT933_ALERT_2_G Number of OMIT Records in Embedded.res File...

PLAT978_ALERT_2_G Number C-C Bonds with Positive Residual Density.

2 Report

5.02 Why ?

1 Report

105.8 Degree

105.2 Degree

105.3 Degree

104.6 Degree

105.1 Degree

105.1 Degree

105.1 Degree

105.3 Degree

1 Note

18 Note

3 Note

8 Note

12 Info

0 ALERT level $\mathbf{A}=$ Most likely a serious problem - resolve or explain

0 ALERT level $\mathbf{B}=\mathrm{A}$ potentially serious problem, consider carefully

7 ALERT level $\mathbf{C}=$ Check. Ensure it is not caused by an omission or oversight

16 ALERT level $\mathbf{G}=$ General information/check it is not something unexpected

0 ALERT type 1 CIF construction/syntax error, inconsistent or missing data

16 ALERT type 2 Indicator that the structure model may be wrong or deficient

5 ALERT type 3 Indicator that the structure quality may be low

2 ALERT type 4 Improvement, methodology, query or suggestion

0 ALERT type 5 Informative message, check 
It is advisable to attempt to resolve as many as possible of the alerts in all categories. Often the minor alerts point to easily fixed oversights, errors and omissions in your CIF or refinement strategy, so attention to these fine details can be worthwhile. In order to resolve some of the more serious problems it may be necessary to carry out additional measurements or structure refinements. However, the purpose of your study may justify the reported deviations and the more serious of these should normally be commented upon in the discussion or experimental section of a paper or in the "special_details" fields of the CIF. checkCIF was carefully designed to identify outliers and unusual parameters, but every test has its limitations and alerts that are not important in a particular case may appear. Conversely, the absence of alerts does not guarantee there are no aspects of the results needing attention. It is up to the individual to critically assess their own results and, if necessary, seek expert advice.

\section{Publication of your CIF in IUCr journals}

A basic structural check has been run on your CIF. These basic checks will be run on all CIFs submitted for publication in IUCr journals (Acta Crystallographica, Journal of Applied Crystallography, Journal of Synchrotron Radiation); however, if you intend to submit to Acta Crystallographica Section C or E or IUCrData, you should make sure that full publication checks are run on the final version of your CIF prior to submission.

\section{Publication of your CIF in other journals}

Please refer to the Notes for Authors of the relevant journal for any special instructions relating to CIF submission.

\section{PLATON version of 13/12/2017; check.def file version of 12/12/2017}


Datablock mo_C20VB206_0ma_a - ellipsoid plot

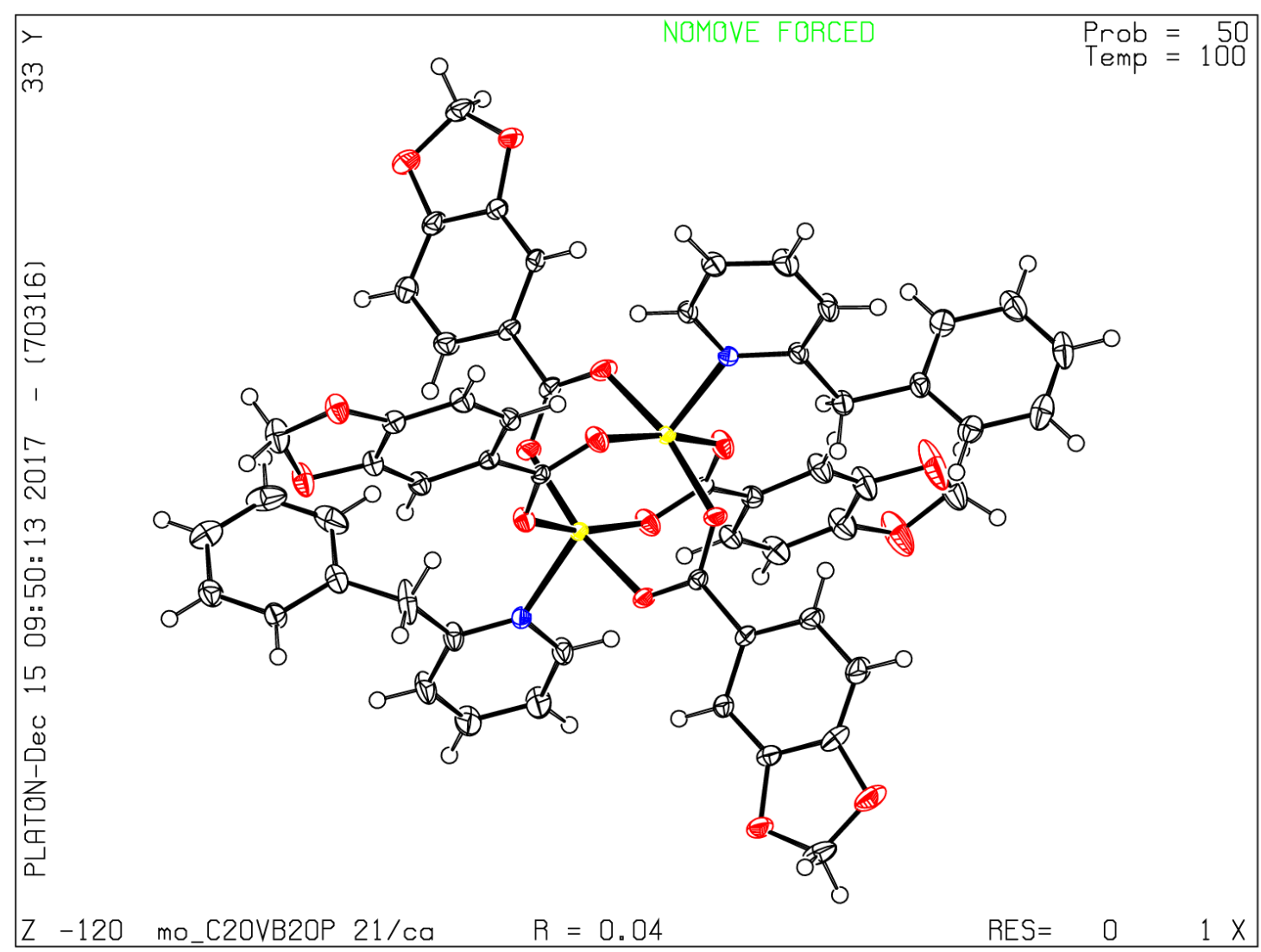

